\title{
PIE on Safety-Tested AGR-1 Compacts 5-3-3, 5-1-3, and 3-2-3
}

This document has been reviewed and is determined to be APPROVED FOR PUBLIC RELEASE.

Name/Title: Leesa Laymance/ORNL TIO

Date: $\underline{5 / 14 / 2020}$

\section{September 2014}

Prepared by

John D. Hunn

Robert N. Morris

Charles A. Baldwin

Fred C. Montgomery

Tyler J. Gerczak

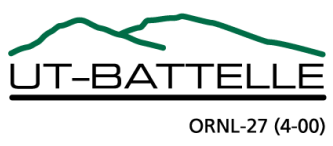


This report was prepared as an account of work sponsored by an agency of the United States Government. Neither the United States Government nor any agency thereof, nor any of their employees, makes any warranty, express or implied, or assumes any legal liability or responsibility for the accuracy, completeness, or usefulness of any information, apparatus, product, or process disclosed, or represents that its use would not infringe privately owned rights. Reference herein to any specific commercial product, process, or service by trade name, trademark, manufacturer, or otherwise, does not necessarily constitute or imply its endorsement, recommendation, or favoring by the United States Government or any agency thereof. The views and opinions of authors expressed herein do not necessarily state or reflect those of the United States Government or any agency thereof. 
ORNL/TM-2014/484

Revision 0

Fusion and Materials for Nuclear Systems Division

\title{
PIE on Safety-Tested AGR-1 Compacts 5-3-3, 5-1-3, and 3-2-3
}

John D. Hunn

Robert N. Morris

Charles A. Baldwin

Fred C. Montgomery

Tyler J. Gerczak

Date Published: September 2014

\author{
Prepared by \\ OAK RIDGE NATIONAL LABORATORY \\ Oak Ridge, Tennessee 37831-6093 \\ managed by \\ UT-BATTELLE, LLC \\ for the \\ UNITED STATES DEPARTMENT OF ENERGY \\ Office of Nuclear Energy \\ under the \\ Very High Temperature Reactor Development Office \\ Advanced Gas Reactor Fuel Development and Qualification Program
}


This page intentionally left blank 


\section{TABLE OF CONTENTS}

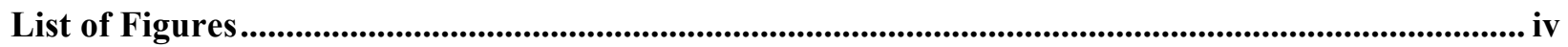

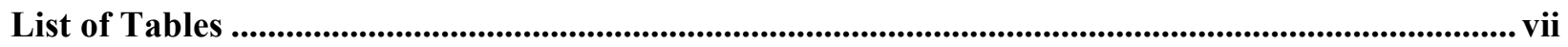

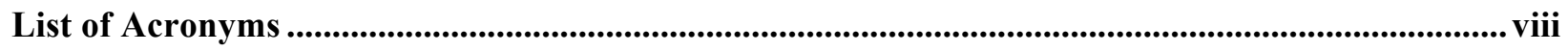

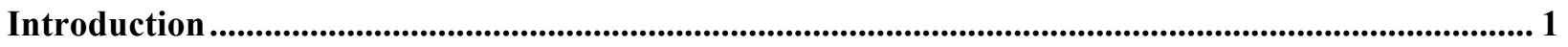

Standard examination procedure ............................................................................................................... 2

Safety testing results ............................................................................................................................................. 4

DLBL results ..................................................................................................................................................... 8

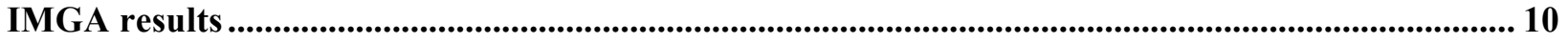

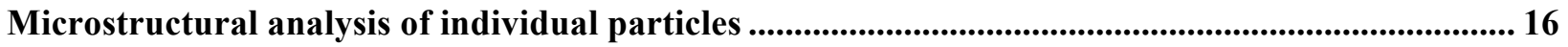

Analysis of particles from randomly-selected IMGA samples ..................................................... 16

Analysis of particles from Compacts 5-1-3 and 3-2-3 that were specially-selected by IMGA due to

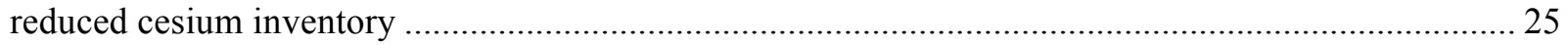

Enumeration of particles with failed SiC ............................................................................................................ 37

Summary and Conclusions............................................................................................................................... 39

Acknowledgments .............................................................................................................................................. 41

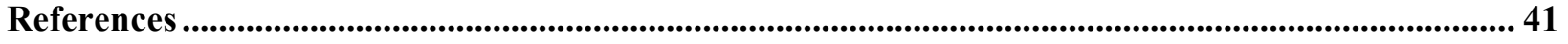




\section{LIST OF FIGURES}

Figure 1. Flow chart of the DLBL process. ........................................................................................ 3

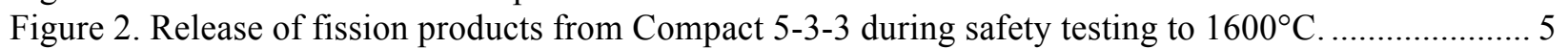

Figure 3. Release of fission products from Compact 5-1-3 during safety testing to $1800^{\circ} \mathrm{C}$................... 5

Figure 4. Release of fission products from Compact 3-2-3 during safety testing to $1800^{\circ} \mathrm{C} \ldots \ldots \ldots \ldots \ldots \ldots \ldots . . . \ldots$

Figure 5. Release rates of cesium from Compacts 5-1-3 and 3-2-3 during safety testing to $1800^{\circ} \mathrm{C} \ldots \ldots \ldots . . .7$

Figure 6. Estimated fraction of ${ }^{137} \mathrm{Cs}$ retained in particles from Compact 5-1-3, based on calculated inventory and adjusted for variation in fissionable material and burn-up using the measured

${ }^{144} \mathrm{Ce}$ activity.

Figure 7. Estimated fraction of ${ }^{137} \mathrm{Cs}$ retained in particles from Compact 3-2-3, based on calculated inventory and adjusted for variation in fissionable material and burn-up using the measured ${ }^{144} \mathrm{Ce}$ activity.

Figure 8. Ratio of ${ }^{110 \mathrm{~m}} \mathrm{Ag}$ retained in 45 particles randomly-selected from Compact 5-3-3. Note that the ${ }^{110 \mathrm{~m}} \mathrm{Ag}$ activity in these particles was very low at the time of analysis and uncertainty in peak analysis ranged from $\sim 12 \%$ for particles with more silver to $\sim 38 \%$ for particles with barely detectable silver. The 18 particles with undetectable inventory contained less than a minimum detectable $\mathrm{M} / \mathrm{C}$ of $0.20-0.24$...

Figure 9. Ratio of ${ }^{110 \mathrm{~m}} \mathrm{Ag}$ retained in 40 particles randomly-selected from Compact 5-1-3.

Uncertainty in ${ }^{110 \mathrm{~m}} \mathrm{Ag}$ peak analysis ranged from $\sim 12 \%$ for particles with more silver to $\sim 29 \%$ for particles with barely detectable silver. The 12 particles with undetectable inventory had an $\mathrm{M} / \mathrm{C}<0.19-0.22$.

Figure 10. Ratio of ${ }^{110 \mathrm{~m}} \mathrm{Ag}$ retained in 60 particles randomly-selected from Compact 3-2-3.

Uncertainty in peak analysis ranged from $\sim 12 \%$ for particles with more silver to $\sim 50 \%$ for particles with barely detectable silver. The 12 particles with undetectable inventory had an $\mathrm{M} / \mathrm{C}<0.23-0.25$.

Figure 11. X-ray tomographs near midplane of (a) Particle 533-RS16 with measurably reduced ${ }^{110 \mathrm{~m}} \mathrm{Ag}$ inventory $(\mathrm{M} / \mathrm{C}<0.22)$ and $(\mathrm{b})$ Particle 533-RS36 with average ${ }^{110 \mathrm{~m}} \mathrm{Ag}$ inventory $(\mathrm{M} / \mathrm{C}=0.88)$. Bright features at the IPyC/SiC interface are fission products. Rings in kernel are tomography artifacts.

Figure 12. Optical micrographs near midplane of particles from Compact 5-3-3: a) Particle 533RS23 with high ${ }^{110 \mathrm{~m}} \mathrm{Ag}$ release $(\mathrm{M} / \mathrm{C}<0.21)$, b) Particle 533-RS20 with moderate ${ }^{110 \mathrm{~m}} \mathrm{Ag}$ release $(\mathrm{M} / \mathrm{C}=0.58)$, c) Particle 533-RS24 with marginal ${ }^{110 \mathrm{~m}} \mathrm{Ag}$ release $(\mathrm{M} / \mathrm{C}=0.81)$, and d) Particle 533-RS04 with very low ${ }^{110 \mathrm{~m}} \mathrm{Ag}$ release $(\mathrm{M} / \mathrm{C}=1.10)$.

Figure 13. Backscattered-electron composition micrographs showing representative IPyC and $\mathrm{SiC}$ of Compact 5-3-3 particles shown in Figure 12: a) Particle 533-RS23 with high ${ }^{110 \mathrm{~m}} \mathrm{Ag}$ release $(\mathrm{M} / \mathrm{C}<0.21)$, b) Particle 533-RS20 with moderate ${ }^{110 \mathrm{~m}} \mathrm{Ag}$ release $\left.(\mathrm{M} / \mathrm{C}=0.58), \mathrm{c}\right)$ Particle 533-RS24 with marginal ${ }^{110 \mathrm{~m}} \mathrm{Ag}$ release $(\mathrm{M} / \mathrm{C}=0.81)$, and d) Particle 533-RS04 with very low ${ }^{110 \mathrm{~m}} \mathrm{Ag}$ release $(\mathrm{M} / \mathrm{C}=1.10)$. Dashed diamonds or squares indicate relatively less Pd or U were detected.

Figure 14. X-ray tomographs near midplane of (a) Particle 513-RS13 with measurably reduced ${ }^{110 \mathrm{~m}} \mathrm{Ag}$ inventory $(\mathrm{M} / \mathrm{C}=0.55)$ and $(\mathrm{b})$ Particle 513-RS09 with above average ${ }^{110 \mathrm{~m}} \mathrm{Ag}$ inventory $(\mathrm{M} / \mathrm{C}=1.09)$. Bright features at the $\mathrm{IPyC} / \mathrm{SiC}$ interface and in the buffer fractures are fission products.

Figure 15. Three-dimensional x-ray visualization of Particle 513-RS09 showing large clusters of fission products in one region of the buffer, as well as smaller clusters distributed uniformly around the $\mathrm{IPyC} / \mathrm{SiC}$ interface.

Figure 16. X-ray tomographs near midplane of particles from Compact 3-2-3 and 3D visualizations highlighting the kernel shape for a) Particle 323-RS34 with very low ${ }^{110 \mathrm{~m}} \mathrm{Ag}$ inventory $(\mathrm{M} / \mathrm{C}<0.24)$, and b) Particle 323-RS17 with negligible ${ }^{110 \mathrm{~m}} \mathrm{Ag}$ release $(\mathrm{M} / \mathrm{C}=1.29)$.

Figure 17. X-ray tomograph near midplane and $3 \mathrm{D}$ visualization highlighting the kernel shape of Particle 323-RS51 with very-low ${ }^{110 \mathrm{~m}} \mathrm{Ag}$ inventory $(\mathrm{M} / \mathrm{C}<0.23)$ and also very-low ${ }^{154} \mathrm{Eu}$ inventory $(\mathrm{M} / \mathrm{C}=0.01)$...... 
Figure 18. Optical micrographs near midplane of particles from Compact 5-1-3: a) Particle 513RS06 with high ${ }^{110 \mathrm{~m}} \mathrm{Ag}$ release $\left.(\mathrm{M} / \mathrm{C}<0.22), \mathrm{b}\right)$ and c) Particle 513-RS26 with moderate ${ }^{110 \mathrm{~m}} \mathrm{Ag}$ release $(\mathrm{M} / \mathrm{C}=0.58)$

Figure 19. SEI/BEC-paired images of Compact 5-1-3 particles shown in Figure 18............................ 23

Figure 20. SEI/BEC-paired images of SiC region in Compact 3-2-3 Particle 323-RS50 with high ${ }^{110 \mathrm{~m}} \mathrm{Ag}$ release $(\mathrm{M} / \mathrm{C}<0.25)$. Dashed diamonds or squares indicate relatively less Pd or $\mathrm{U}$

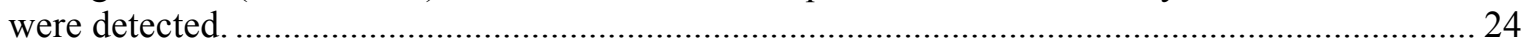

Figure 21. X-ray tomograph of Particle 513-SP02 showing undersized kernel. ..................................... 25

Figure 22. Kernels from Particles 323-SP09, SP11, and SP12 ....................................................... 25

Figure 23. X-ray tomograph of Particle 323-SP09 showing IPyC cracks with associated fission product pile-up (bright regions) and $\mathrm{SiC}$ degradation in the vicinity of the IPyC crack. This particle had slightly low cesium, silver, and europium (Table 8).

Figure 24. Pair of orthogonal x-ray tomographs showing region of $\mathrm{SiC}$ failure in Particle 513-SP03: buffer fracture $\rightarrow \mathrm{IPyC}$ crack $\rightarrow \mathrm{IPyC} / \mathrm{SiC}$ delamination and tangential $\mathrm{SiC}$ crack $\rightarrow$ fission product concentration and $\mathrm{SiC}$ degradation at the bottom of image.

Figure 25. Pair of orthogonal X-ray tomographs showing region of SiC failure in Particle 513-SP04: buffer fracture with kernel protrusion $\rightarrow$ buffer/IPyC delamination $\rightarrow$ IPyC crack $\rightarrow$ $\mathrm{IPyC} / \mathrm{SiC}$ delamination $\rightarrow$ fission product concentration and $\mathrm{SiC}$ degradation at the bottom of image.

Figure 26. Pair of orthogonal x-ray tomographs showing region of SiC failure in Particle 513-SP05: buffer fracture with kernel protrusion $\rightarrow$ buffer/IPyC delamination $\rightarrow$ IPyC crack $\rightarrow$ $\mathrm{IPyC} / \mathrm{SiC}$ delamination $\rightarrow$ fission product concentration and $\mathrm{SiC}$ degradation at the bottom of image.

Figure 27. Pair of orthogonal x-ray tomographs showing region of SiC failure in Particle 513-SP06: buffer fracture with kernel protrusion $\rightarrow$ buffer/IPyC delamination $\rightarrow$ IPyC crack $\rightarrow$ $\mathrm{IPyC} / \mathrm{SiC}$ delamination $\rightarrow$ fission product concentration and $\mathrm{SiC}$ degradation at the bottom of image.

Figure 28. Pair of orthogonal x-ray tomographs showing possible region of $\mathrm{SiC}$ failure in Particle 513-SP07: buffer/IPyC delamination $\rightarrow \mathrm{IPyC}$ crack $\rightarrow \mathrm{IPyC} / \mathrm{SiC}$ delamination and tangential $\mathrm{SiC}$ crack $\rightarrow$ fission product concentration and $\mathrm{SiC}$ degradation at the bottom of image.

Figure 29. Two pairs of orthogonal x-ray tomographs showing two possible regions of $\mathrm{SiC}$ failure in Particle 323-SP01: a) buffer fracture with kernel protrusion $\rightarrow \mathrm{IPyC}$ crack $\rightarrow \mathrm{IPyC} / \mathrm{SiC}$ delamination $\rightarrow$ tangential $\mathrm{SiC}$ crack $\rightarrow$ radial $\mathrm{SiC}$ crack or $\mathrm{SiC}$ degradation at the bottom of image, and b) buffer fracture $\rightarrow \mathrm{IPyC}$ crack $\rightarrow \mathrm{IPyC} / \mathrm{SiC}$ delamination $\rightarrow$ fission product concentration and $\mathrm{SiC}$ degradation at the bottom of image. Note that Figure 29b corresponds to $\sim 160^{\circ}$ clockwise rotation of Figure 29a plus a small out of plane rotation; the edge of the degraded region at the bottom of Figure $29 \mathrm{~b}$ can be seen in the upper right quadrant of Figure 29a.

Figure 30. Pair of orthogonal x-ray tomographs showing regions of SiC failure in Particle 323$\mathrm{SP} 02:$ buffer fracture $\rightarrow \mathrm{IPyC}$ crack $\rightarrow \mathrm{IPyC} / \mathrm{SiC}$ delamination $\rightarrow$ fission product concentration and $\mathrm{SiC}$ degradation at the bottom of image.

Figure 31. Pair of orthogonal x-ray tomographs showing regions of SiC failure in Particle 323SP03: buffer fracture with significant kernel protrusion $\rightarrow$ IPyC crack with kernel protrusion $\rightarrow$ fission product concentration and $\mathrm{SiC}$ degradation at the bottom of image.

Figure 32. Pair of orthogonal x-ray tomographs showing regions of SiC failure in Particle 323SP04: buffer fracture with kernel protrusion $\rightarrow$ IPyC crack $\rightarrow$ fission product concentration and $\mathrm{SiC}$ degradation at the bottom of image.

Figure 33. Pair of orthogonal x-ray tomographs showing regions of SiC failure in Particle 323SP05: buffer fracture with kernel protrusion $\rightarrow$ IPyC crack $\rightarrow$ fission product concentration and $\mathrm{SiC}$ degradation at the bottom of image. 
Figure 34. Pair of orthogonal x-ray tomographs showing regions of SiC failure in Particle 323SP06: buffer fracture with kernel protrusion $\rightarrow$ IPyC crack with kernel protrusion $\rightarrow$ fission product concentration and $\mathrm{SiC}$ degradation at the bottom of image.

Figure 35. Pair of orthogonal x-ray tomographs showing regions of $\mathrm{SiC}$ failure in Particle 323$\mathrm{SP}$ 07: buffer fracture $\rightarrow$ IPyC crack $\rightarrow$ fission product concentration and SiC degradation at the bottom of image.

Figure 36. Pair of orthogonal X-ray tomographs showing regions of $\mathrm{SiC}$ failure in Particle 323$\mathrm{SP} 08:$ buffer fracture $\rightarrow \mathrm{IPyC}$ crack $\rightarrow \mathrm{IPyC} / \mathrm{SiC}$ delamination $\rightarrow$ fission product concentration and $\mathrm{SiC}$ degradation at the bottom of image.

Figure 37. Pair of orthogonal x-ray tomographs showing regions of SiC failure in Particle 323SP09: buffer fracture with kernel protrusion $\rightarrow$ buffer/IPyC delamination $\rightarrow$ IPyC crack $\rightarrow$ $\mathrm{IPyC} / \mathrm{SiC}$ delamination $\rightarrow$ fission product concentration and $\mathrm{SiC}$ degradation at the bottom of image. 34

Figure 38. SiC failure in Particle 323-SP05, which released cesium (Table 8): a) x-ray tomograph prior to sectioning and $b$ ) optical micrograph of polished section.

Figure 39. SEI/BEC-paired images of SiC region in Compact 3-2-3 Particle 323-SP05, which released cesium (Table 8). Dashed diamonds or squares indicate relatively less Pd or U were detected.

Figure 40. SEI/BEC-paired images of SiC region in Compact 3-2-3 Particle 323-SP08, which released cesium (Table 8). Dashed diamonds or squares indicate relatively less Pd or U were detected. 


\section{LIST OF TABLES}

Table 1. Final irradiation conditions at the end of the AGR-1 irradiation test ........................................ 1

Table 2. Cumulative releases of radioactive isotopes at the end of safety testing ..................................... 7

Table 3. Isotopes detected at various stages of DLBL analysis .......................................................... 9

Table 4. Distribution of europium (and strontium in parentheses) outside of SiC ................................. 10

Table 5. Ratio of measured [Harp 2013] to calculated [Sterbentz 2013] activity of various gammaemitting isotopes in Capsule 3 compacts showing unusually high activity in Compact 3-2-3 ....... 12

Table 6. Radioactive isotopes detected in particles from Compact 5-3-3 ............................................ 12

Table 7. Radioactive isotopes detected in particles from Compact 5-1-3 ............................................ 13

Table 8. Radioactive isotopes detected in particles from Compact 3-2-3 ............................................. 14

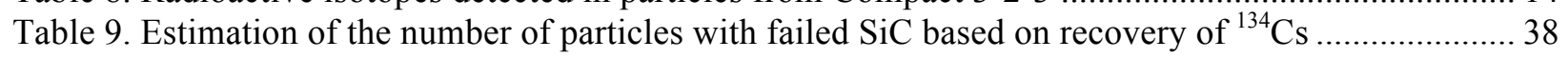

Table 10. Estimation of the number of particles with failed $\mathrm{SiC}$ based on counting with IMGA and

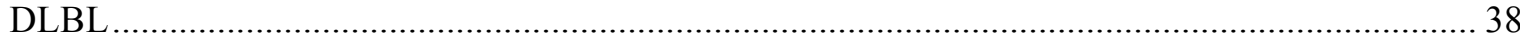




\section{LIST OF ACRONYMS}

\begin{tabular}{ll} 
AGR & Advanced Gas Reactor \\
ART & Advanced Reactor Technologies \\
ATR & Advanced Test Reactor \\
BEC & Backscattered Electron Composition \\
CCCTF & Core Conduction Cooldown Test Facility \\
DLBL & Deconsolidation Leach-Burn-Leach \\
EDS & Energy Dispersive Spectrometry \\
FIMA & Fissions per Initial Metal Atom \\
HTGR & High Temperature Gas-cooled Reactor \\
IFEL & Irradiated Fuels Examination Laboratory (ORNL Building 3525) \\
IMGA & Irradiated Microsphere Gamma Analyzer \\
INL & Idaho National Laboratory \\
IPyC & Inner Pyrolytic Carbon (layer) \\
LEU & Low Enriched Uranium \\
M/C & Measured versus Calculated ratio \\
OPyC & Outer Pyrolytic Carbon (layer) \\
ORNL & Oak Ridge National Laboratory \\
PIE & Post-Irradiation Examination \\
RS & Randomly-Selected particles \\
SEI & Secondary Electron Imaging \\
SEM & Scanning Electron Microscope \\
SiC & Silicon Carbide (layer) \\
SP & Specially-selected Particles \\
QC & Quality Control \\
TAVA & Time-Averaged/Volume-Averaged temperature \\
TRISO & TRi-ISOtropic (coated particles) \\
UCO & Uranium Carbide/uranium Oxide (kernels) \\
Z & Atomic number \\
\hline
\end{tabular}




\section{INTRODUCTION}

Post-irradiation examination (PIE) is being performed in support of tristructural isotropic (TRISO) coated particle fuel development and qualification for High Temperature Gas-cooled Reactors (HTGRs). AGR-1 was the first in a series of TRISO fuel irradiation experiments initiated in 2006 under the Advanced Gas Reactor (AGR) Fuel Development and Qualification Program; this work continues to be funded by the Department of Energy's Office of Nuclear Energy in support of Advanced Reactor Technologies (ART). AGR-1 fuel compacts were fabricated at Oak Ridge National Laboratory (ORNL) in 2006 and irradiated for 3 years in the Advanced Test Reactor (ATR) at Idaho National Laboratory (INL) to demonstrate and evaluate fuel performance under HTGR irradiation conditions. PIE is being performed at INL and ORNL to study how the fuel behaved during irradiation, and to test fuel performance during exposure to elevated temperatures at or above temperatures that could occur during a depressurized conduction cooldown event. This report summarizes safety testing and post-safety testing PIE recently completed at ORNL on irradiated AGR-1 Compacts 5-3-3, 5-1-3, and 3-2-3.

Fabrication and characterization data for the pre-irradiated compacts can be found in the individual data packages and pre-irradiation summary report [Hunn, Savage, and Silva 2012]. Compact 3-2-3 was an AGR-1 Baseline fuel type [Hunn and Lowden 2006-1; Hunn and Lowden 2006-2] while Compacts 5-3-3 and 5-1-3 were Variant 1 [Hunn, Montgomery, and Pappano 2006-1; Hunn, Montgomery, and Pappano 2006-2]. Baseline and Variant 1 fuel particles had similar characteristics except for the inner pyrolytic carbon layer (IPyC), which had a lower density in Variant $1\left(1.85 \mathrm{~g} / \mathrm{cm}^{3}\right.$ versus $1.90 \mathrm{~g} / \mathrm{cm}^{3}$ in Baseline fuel). Safety testing was performed in the ORNL Core Conduction Cooldown Test Facility (CCCTF). After irradiation (see Table 1), the compacts were heated in helium atmosphere to a temperature of $1600^{\circ} \mathrm{C}$ (Compact 5-3-3) or $1800^{\circ} \mathrm{C}$ (Compacts 5-1-3 and 3-2-3), and held at that temperature for $300 \mathrm{~h}$ while monitoring for fission product ${ }^{1}$ release. After completion of the safety tests, the compacts were examined with a standard set of analyses that included the following: (1) detection of exposed fission products by Deconsolidation-Leach-Burn-Leach (DLBL), (2) measurement of the gamma-emitting isotopic inventory within individual particles with the ORNL Irradiated Microsphere Gamma Analyzer (IMGA), and (3) microstructural examination by high-resolution x-ray tomography and materialography. The equipment and methods used for the safety testing and post-safety testing PIE are summarized in the next section of this report and have previously been described in detail [Baldwin et al. 2012; Hunn et al. 2013-1]. This report also provides a brief summary of the results of the safety tests and subsequent PIE. Preliminary trends are discussed, but final conclusions are reserved for a comprehensive AGR-1 PIE summary that will include data from PIE of other compacts from the AGR-1 irradiation test.

Table 1. Final irradiation conditions at the end of the AGR-1 irradiation test

\begin{tabular}{|c||c|c|c|}
\hline & Compact 5-3-3 & Compact 5-1-3 & Compact 3-2-3 \\
\hline AGR-1 fuel type & Variant 1 & Variant 1 & Baseline \\
\hline Fabrication ID & LEU01-47T-Z71 & LEU01-47T-Z55 & LEU01-46T-Z55 \\
\hline Burnup [Sterbentz 2013] & $17.0 \% \mathrm{FIMA}$ & $18.2 \% \mathrm{FIMA}$ & $19.1 \% \mathrm{FIMA}$ \\
\hline Fast Fluence [Sterbentz 2013] & $3.65 \times 10^{25} \mathrm{n} / \mathrm{m}^{2}$ & $3.82 \times 10^{25} \mathrm{n} / \mathrm{m}^{2}$ & $4.28 \times 10^{25} \mathrm{n} / \mathrm{m}^{2}$ \\
\hline Temperature [Hawkes 2012] & $1042^{\circ} \mathrm{C} \mathrm{TAVA}$ & $1042^{\circ} \mathrm{C} \mathrm{TAVA}$ & $1053^{\circ} \mathrm{C} \mathrm{TAVA}$ \\
\hline
\end{tabular}

FIMA $=$ fissions per initial metal atom

TAVA $=$ time-averaged and volume-averaged

\footnotetext{
${ }^{1}$ In this report, the term "fission product" is used in a general sense to refer to all the post-fission isotopes remaining at the end of the irradiation test. These include: isotopes directly generated by the fission process, isotopes generated by neutron activation, isotopes generated by radioactive decay, and residual uranium.
} 


\section{STANDARD EXAMINATION PROCEDURE}

[edited extract from Hunn et al. 2013-3]

Safety testing was performed in flowing helium, with compacts held at the maximum test temperature for $300 \mathrm{~h}$. During the test period, metallic elements released from the compacts were collected by a watercooled cold finger at the top of the CCCTF furnace, and gaseous fission products were extracted from the helium sweep gas as it passed through liquid nitrogen-cooled cold traps located downstream. Deposition cups attached to the in-furnace cold finger were periodically removed and analyzed by gamma spectrometry and the sweep gas traps were constantly monitored for gamma activity throughout each run.

After completion of the safety testing, acid leaching and additional analyses were performed on the deposition cups and CCCTF furnace internals (graphite fuel holder, tantalum furnace liner, and tantalum gas inlet line). The average deposition cup collection efficiency for each detected isotope was determined as the ratio of the cumulative amount on all the deposition cups to the total detected on the cups and other CCCTF internal components. The measured data for each individual deposition cup were adjusted by these collection efficiencies to estimate the time-dependent release of each detected isotope from the compact throughout the safety test.

Additional post-safety test PIE was also performed on each compact (leach-burn-leach, individual particle gamma spectrometry, $\mathrm{x}$-ray tomography, and materialography). Compacts were first electrolytically deconsolidated in nitric acid to break up the matrix carbon and release the TRISO-coated particles from the compact. Particles and matrix residue were then leached twice with hot nitric acid in a Soxhlet extractor to dissolve any soluble elements in the matrix residue or on the surface of the particles. This leaching step will also dissolve uranium in exposed kernels from particles with fractured TRISO coatings.

After the deconsolidation-leach (DL), if significant cesium release was detected during the safety test, then TRISO-coated particles were separated out from the matrix residue for IMGA survey (this was the case for Compacts 5-1-3 and 3-2-3). Particles were separated from the matrix residue by first boiling in nitric acid to clean off any residual matrix from the outer surface of the TRISO particles, and then washing the matrix residue and acid through a sieve with $500-\mu \mathrm{m}$-square holes. The washed and dried particles were then transferred to the IMGA hot cell for gamma analysis. The matrix residue was dried and burned at $750^{\circ} \mathrm{C}$ to oxidize any remaining elements. Boiling nitric acid was then used to leach the ash. After IMGA examination, approximately $90 \%$ of the particles were returned to the Soxhlet thimble for burn-leach (BL). During this BL, the outer pyrocarbon and elements remaining on the surface of the particles that were not dissolved during the pre-burn leach are oxidized. The burn-leach will also detect exposed uranium in any particles with through-wall defects in the $\mathrm{SiC}$ that were protected by intact pyrocarbon during the pre-burn leaching and not removed by IMGA due to low cesium content. If cesium release was not detected during the safety test (as was the case for Compact 5-3-3), then particles and matrix were burned and leached together. The flow chart in Figure 1 outlines the DLBL process. 


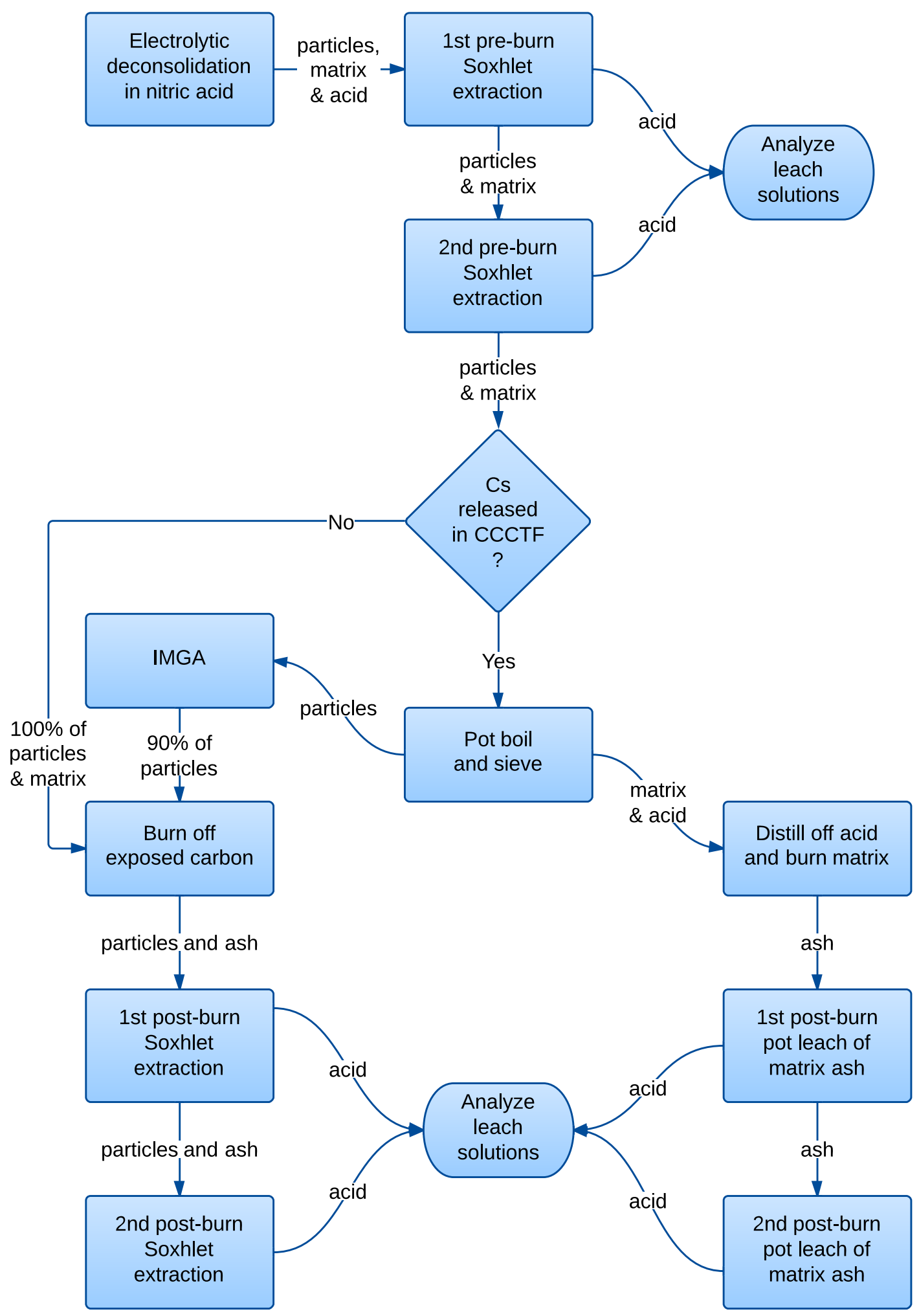

Figure 1. Flow chart of the DLBL process. 
TRISO-coated particles from compacts that released significant cesium were surveyed for ${ }^{137} \mathrm{Cs}$ and ${ }^{144} \mathrm{Ce}$ inventory with the IMGA using a 100-120 sec counting time. The IMGA uses a computer-controlled pneumatic particle manipulator to remove individual particles from a hopper, transfer them to a gamma scanning station, and then sort them into specified containers based on the measured gamma spectra. This process requires about two weeks to analyze and sort all $4100+$ particles from each compact. Particles were primarily sorted according to their ${ }^{144} \mathrm{Ce}$ content, where particles with significantly low ${ }^{144} \mathrm{Ce}$ inventory were placed in a separate receptacle for further analysis. Particles with essentially normal ${ }^{144} \mathrm{Ce}$ inventory were sorted by their ${ }^{137} \mathrm{Cs} /{ }^{144} \mathrm{Ce}$ ratio, and particles with a low ratio were deposited into designated vials. Particles with significantly below-average cerium content could contain abnormally small kernels or kernels that were leached by the DL process. A low ${ }^{137} \mathrm{Cs} /{ }^{144} \mathrm{Ce}$ ratio implies particles have preferentially lost cesium, which generally indicates a through-wall defect in the SiC layer. After the IMGA survey, particles identified as having anomalous ${ }^{144} \mathrm{Ce}$ or ${ }^{137} \mathrm{Cs}$ inventory were surveyed for $5 \mathrm{~h}$ to increase the accuracy of the gamma spectra and measure other lower activity gamma emitters. For all compacts, 40-60 randomly-selected particles were also scanned for $5 \mathrm{~h}$ to examine the average inventory of various detectable isotopes, including ${ }^{95} \mathrm{Zr},{ }^{106} \mathrm{Ru},{ }^{110 \mathrm{~m}} \mathrm{Ag},{ }^{125} \mathrm{Sb},{ }^{134} \mathrm{Cs},{ }^{137} \mathrm{Cs},{ }^{144} \mathrm{Ce}$, and ${ }^{154} \mathrm{Eu}$.

After IMGA examination, particles were selected for microstructural analysis. Particles with anomalous isotopic inventories were compared to average particles. Emphasis was given to particles that exhibited different silver retention to look for any unique features. Microstructural analysis included x-ray imaging and materialographic inspection by mechanical polishing followed by analysis using optical and scanning electron microscopes.

Three-dimensional microstructural analysis was achieved using a high-resolution x-ray tomography system specifically designed for imaging TRISO-coated particles. This system can image coating structure with resolution close to $1 \mu \mathrm{m}$, and has been used during AGR-1 fuel development to characterize and understand defect structures in unirradiated, as-fabricated particles in a manner not previously available. For AGR-1 PIE, a shielded container has been designed for mounting irradiated particles on the $\mathrm{x}$-ray tomography stage. This shielded container allows single particles to be removed from the hot cell and transported to the tomography instrument for imaging. The shielding also reduces gamma radiation interference in the detector and electronics. Radiographic image sets using 3200 particle orientations were acquired to support high-resolution three-dimensional (3D) tomographic reconstruction of the irradiated particle microstructure.

Mechanical polishing to reveal particle cross sections was achieved by mounting particles in epoxy and grinding/polishing with a Buehler Minimet 1000. Vacuum back-potting was used to prevent damage to the internal structure and improve the quality of the final polished cross section. Kernels and coating layers were imaged using an optical microscope. Scanning electron microscopy (SEM) was performed on some samples to provide additional information. Secondary-electron image (SEI) and backscatteredelectron composition (BEC) modes were used to examine the structure and detect fission product clusters outside of the kernel, which were identified with Energy Dispersive Spectrometry (EDS).

\section{SAFETY TESTING RESULTS}

Fission product release during safety testing of Variant 1 Compacts 5-3-3 and 5-1-3 was previously reported [Hunn et al. 2013-4]; data from these tests are also included in this section for comparison to Baseline Compact 3-2-3 results and to support discussion in the post-safety testing PIE sections of this report. Compact 5-3-3 was taken to a maximum test temperature of $1600^{\circ} \mathrm{C}$ and held there for 300 hours. The overall time-dependent results of the Compact 5-3-3 furnace test are shown in Figure 2. The plotted fractional release values are the cumulative amount of each fission product collected on the deposition cups, adjusted for radioactive decay and average collection efficiency, and divided by the predicted compact inventory for each fission product at the end of the irradiation. The test was completed without interruption, and observed fission product release was similar to other $1600^{\circ} \mathrm{C}$ tests. Cesium release was very low; only the ${ }^{134} \mathrm{Cs}$ isotope is reported because measured ${ }^{137} \mathrm{Cs}$ activities were below the detection limit for this longer-lived isotope, which has higher background interference from decades of 
accumulated hot cell contamination. Compact 5-1-3 was taken to a maximum test temperature of $1800^{\circ} \mathrm{C}$ and held there for 300 hours; this was the second $1800^{\circ} \mathrm{C}$ AGR-1 safety test (AGR-1 Variant 3 Compact 4-4-1 was tested at $1800^{\circ} \mathrm{C}$ in FY2013). The final heating profile and overall time-dependent release results of the Compact 5-1-3 furnace test are shown in Figure 3.

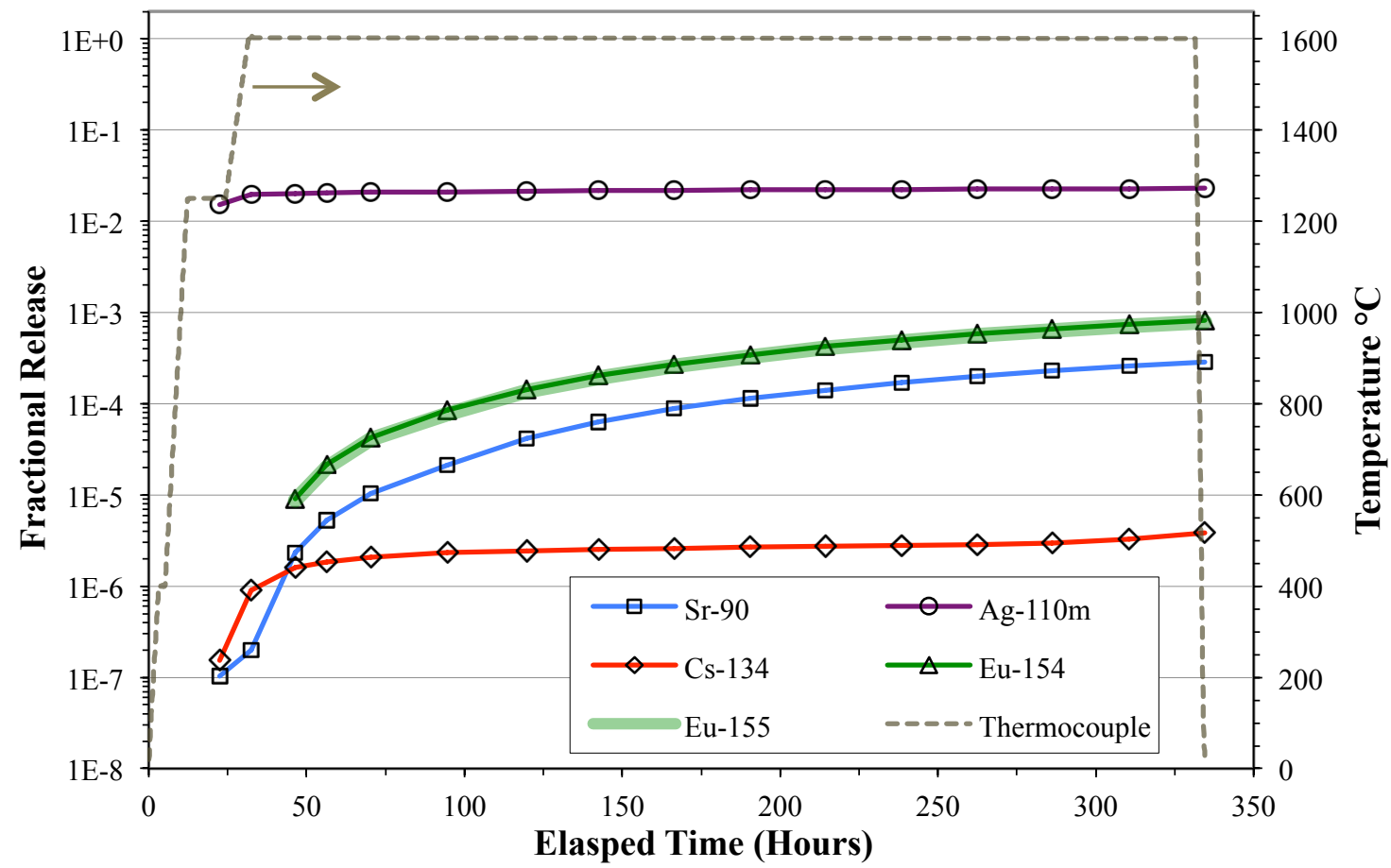

Figure 2. Release of fission products from Compact 5-3-3 during safety testing to $1600^{\circ} \mathrm{C}$.

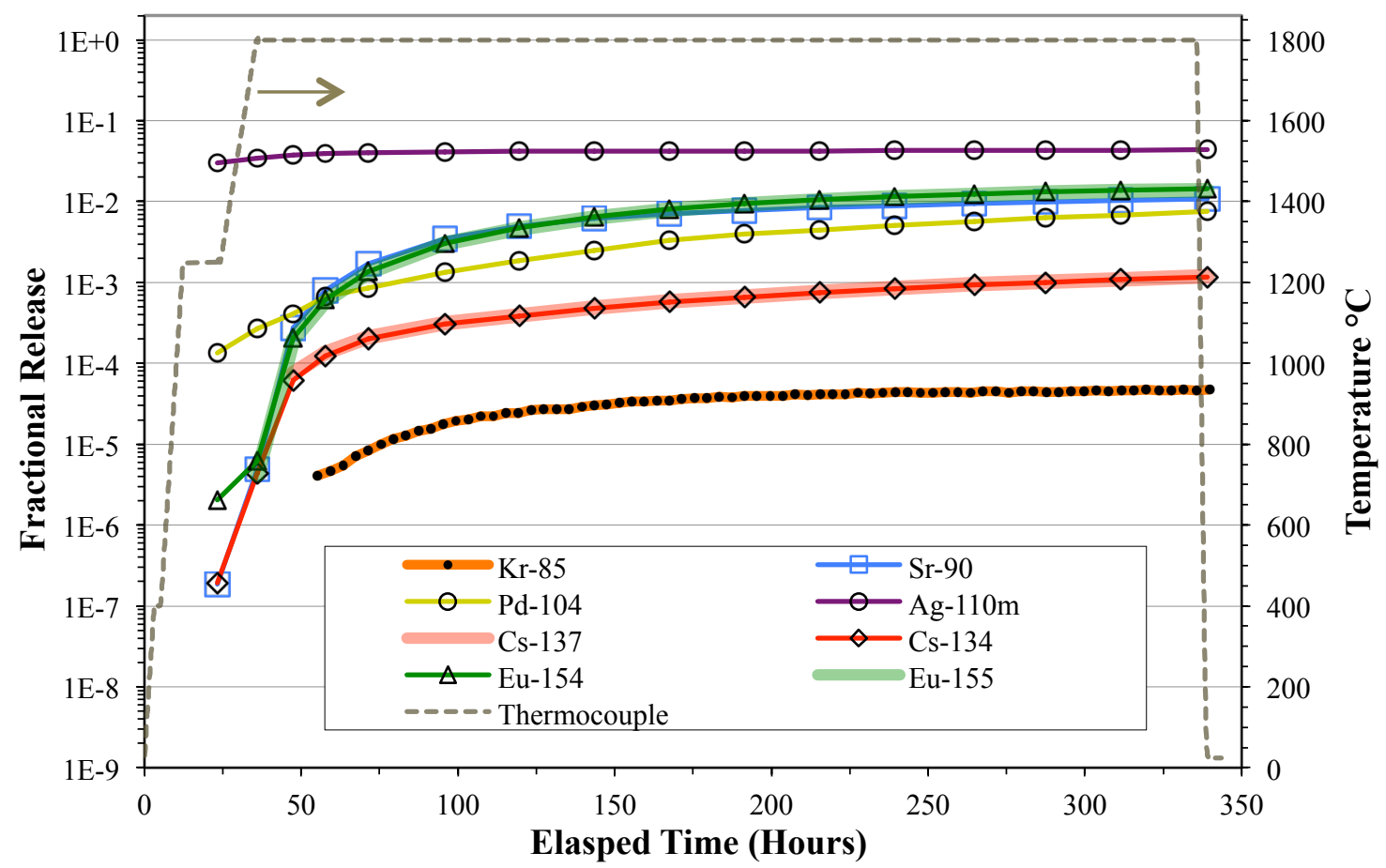

Figure 3. Release of fission products from Compact 5-1-3 during safety testing to $1800^{\circ} \mathrm{C}$. 
Compact 3-2-3 was held at $1800^{\circ} \mathrm{C}$ for 300 hours and the overall time-dependent release results are shown in Figure 4. This was the third AGR-1 safety test performed in the CCCTF at $1800^{\circ} \mathrm{C}$. The test was completed without interruption, and observed fission product release behavior was very similar to the $1800^{\circ} \mathrm{C}$ test of Compact 5-1-3. Neither of these safety tests exhibited the increased release rate for silver, europium, and strontium that was observed during the $1800^{\circ} \mathrm{C}$ test of Compact 4-1-1 [Hunn et al. 2013-2] and discussed in the Compact 5-1-3 safety test summary report [Hunn et al. 2013-4]. Compacts 3-2-3 and 5-1-3 showed the same rapid and early silver releases observed at lower temperature, such as that observed for the Compact 5-3-3 test at $1600^{\circ} \mathrm{C}$. This silver release behavior is presumed to be dominated by release from the matrix and outer pyrolytic carbon (OPyC) of silver previously released during irradiation through intact $\mathrm{SiC}$.

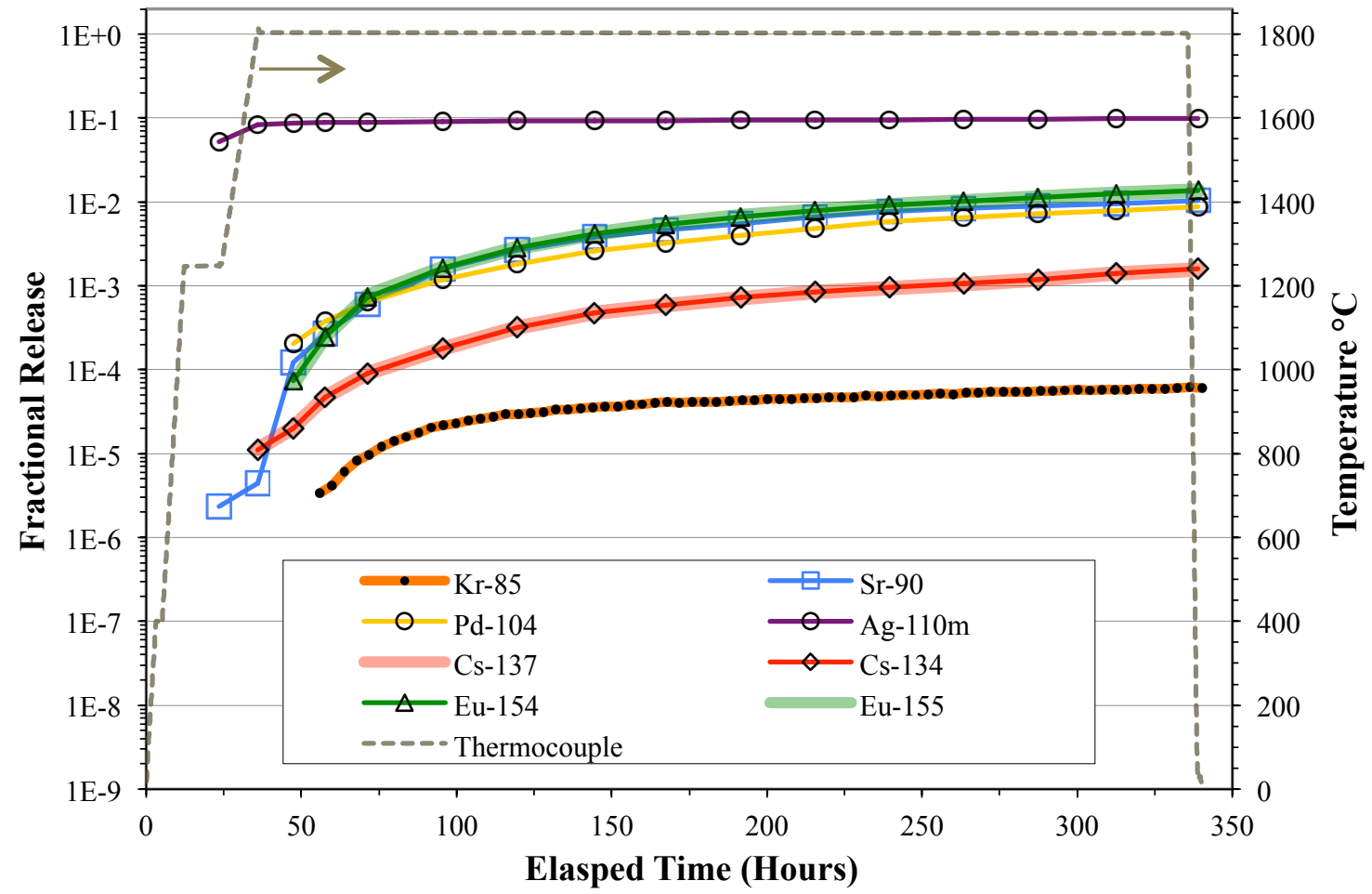

Figure 4. Release of fission products from Compact 3-2-3 during safety testing to $1800^{\circ} \mathrm{C}$.

Table 2 lists the total detected fission product releases at the end of each safety test. The cumulative releases from the two $1800^{\circ} \mathrm{C}$ tests were higher than at $1600^{\circ} \mathrm{C}$ and very similar to each other, with the exception of silver, which was markedly higher for Compact 3-2-3. This higher silver release may have been due to higher silver retention in the Compact 3-2-3 matrix and OPyC $\left({ }^{110 \mathrm{~m}} \mathrm{Ag}\right.$ release from Compact 3-2-3 during irradiation was relatively low compared to Compact 5-1-3 [Harp 2013]).

Cesium release from Compact 5-3-3 during $1600^{\circ} \mathrm{C}$ safety testing was insignificant, indicating there were no particles in the compact with through-layer defects in the $\mathrm{SiC}$; in contrast, significant cesium was released from the two compacts tested at $1800^{\circ} \mathrm{C}$, indicating that these compacts contained multiple particles with failed $\mathrm{SiC}$. Measurable krypton release was also observed at $1800^{\circ} \mathrm{C}$, but not at a level that would indicate a failed TRISO coating. Presumably, this krypton was coming from particles with failed $\mathrm{SiC}$, perhaps as it slowly penetrated the intact OPyC. Figure 5 shows how the cesium release rates from Compacts 5-1-3 and 3-2-3 varied throughout the tests; several peaks can be resolved in each trace. However, each peak cannot be assigned to a single particle failure and there were more particles with failed $\mathrm{SiC}$ than there were peaks in the cesium release rates for these two compacts. Enumeration of the number of particles whose $\mathrm{SiC}$ layer failed and released cesium during these two $1800^{\circ} \mathrm{C}$ safety tests is discussed further below. 
Table 2. Cumulative releases of radioactive isotopes at the end of safety testing

\begin{tabular}{|c|c|c|c|}
\hline Isotope & Compact 5-3-3 at $1600^{\circ} \mathrm{C}$ & Compact 5-1-3 at $1800^{\circ} \mathrm{C}$ & Compact $3-2-3$ at $1800^{\circ} \mathrm{C}$ \\
\hline${ }^{85} \mathrm{Kr}$ & $<1 \mathrm{E}-6 \quad(<4 \mathrm{E}-3)$ & $4.76 \mathrm{E}-5$ & $6.09 \mathrm{E}-5$ \\
\hline${ }^{90} \mathrm{Sr}$ & $2.89 \mathrm{E}-4 \quad(1.2)$ & $1.07 \mathrm{E}-2$ & $1.03 \mathrm{E}-2$ \\
\hline${ }^{104} \mathrm{Pd}$ & not measurable & $7.52 \mathrm{E}-3$ & $8.75 \mathrm{E}-3$ \\
\hline${ }^{110 m} \mathrm{Ag}$ & $2.30 \mathrm{E}-2 \quad(95)$ & $4.35 \mathrm{E}-2$ & $9.93 \mathrm{E}-2$ \\
\hline${ }^{134} \mathrm{Cs}$ & $3.80 \mathrm{E}-6 \quad(0.016)$ & $1.17 \mathrm{E}-3$ & $1.60 \mathrm{E}-3$ \\
\hline${ }^{137} \mathrm{Cs}$ & $<1 \mathrm{E}-5 \quad(<0.04)$ & $1.18 \mathrm{E}-3$ & $1.57 \mathrm{E}-3$ \\
\hline${ }^{154} \mathrm{Eu}$ & $8.28 \mathrm{E}-4 \quad(3.4)$ & $1.43 \mathrm{E}-2$ & $1.36 \mathrm{E}-2$ \\
\hline${ }^{155} \mathrm{Eu}$ & $7.87 \mathrm{E}-4 \quad(3.3)$ & $1.39 \mathrm{E}-2$ & $1.37 \mathrm{E}-2$ \\
\hline
\end{tabular}

Release values are reported as a fraction of the calculated post-irradiation compact inventory [from Sterbentz 2013], with the equivalent number of exposed kernels shown in parentheses, which was calculated as the compact inventory fraction times the average number of particles in the compact (4150 particles/compact for Capsule 5 and 4145 particles/compact for Capsule 3 [Hunn, Savage, and Silva 2012]).

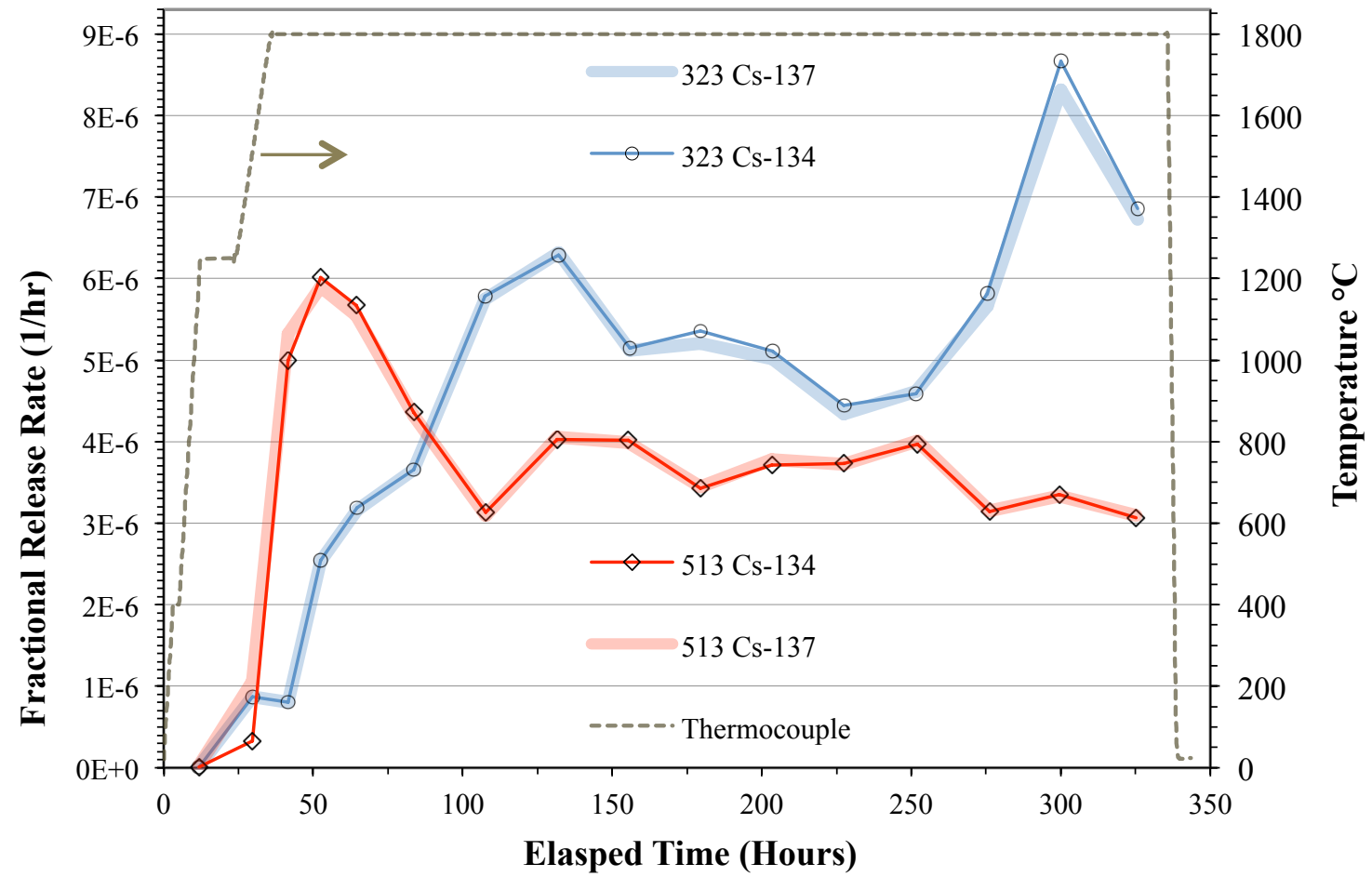

Figure 5. Release rates of cesium from Compacts 5-1-3 and 3-2-3 during safety testing to $1800^{\circ} \mathrm{C}$.

Palladium, europium, and strontium releases were also relatively high from the compacts tested at $1800^{\circ} \mathrm{C}$, and at levels that could not be wholly explained by the presence of particles with failed SiC. Palladium releases were in a range that could be explained by release from the matrix and OPyC, similar to the proposed source for the silver release, but occurring on a slower time scale during the safety test due to its less-volatile nature. Europium and strontium release appeared to be above the expected range of what was typically trapped in the matrix and $\mathrm{OPyC}$ at the end of irradiation. In fact, comparison of Compact 3-2-3 furnace release to Compact 3-2-1 as-irradiated DLBL (an adjacent compact with nearly identical irradiation conditions) suggests order-of-magnitude higher release from Compact 3-2-3 during safety testing [Demkowicz et al. 2014]. 


\section{DLBL RESULTS}

Table 3 summarizes the results of the DLBL analyses for some of the key isotopes generated by the irradiation test. These results indicate how much of each isotope not contained within intact $\mathrm{SiC}$ was detected in the compacts before and after the burn step, where the burn step oxidizes exposed carbon and most exposed metallic elements not previously leached. Results are presented in terms of the compact inventory fraction and the equivalent number of exposed kernels (in parentheses). The compact inventory fraction was determined by dividing the measured amount of each isotope by the amount that was calculated to be in the fuel as a result of the three-year irradiation and subsequent radioactive decay, assuming no isotopic release during irradiation [Sterbentz 2013]. The equivalent number of exposed kernels was determined from the compact inventory fraction by multiplying by the average number of particles in each compact (4150 particles/compact for Capsule 5 and 4145 particles/compact for Capsule 3 [Hunn, Savage, and Silva 2012]). In Table 3, pre-burn data is presented in two parts. The first column of pre-burn data was obtained using the two standard pre-burn Soxhlet extractions (Figure 1). The second column of pre-burn data was obtained from analysis of the rinse solutions collected after a water rinse of the particles and Soxhlet apparatus following the second pre-burn leach and an alcohol rinse of the sieved particles prior to IMGA.

Detection of uranium during DLBL is a good indicator for exposed kernels. If none of the TRISO layers in a particle are intact at the start of DLBL, then acid will dissolve uranium in the exposed kernel during the first pre-burn leach. If intact pyrocarbon protects the kernel from acid in a particle with failed SiC, then uranium will not be dissolved in the pre-burn leaches, but the burn step will remove the pyrocarbon and expose the kernel to post-burn leaching. Compact 5-3-3 DLBL showed no indication of exposed kernels in pre-burn or post-burn leaching; this was in good agreement with the safety test results, where krypton and cesium releases were negligible, indicating no failed TRISO or failed $\mathrm{SiC}$, respectively.

Based on the amount of cesium detected on the deposition cups and the absence of ${ }^{85} \mathrm{Kr}$ in the sweep gas, Compacts 5-1-3 and 3-2-3 were expected to contain particles with failed $\mathrm{SiC}$ but at least one intact pyrocarbon layer (x-ray imaging discussed below found that the OPyC layer was the one that remained intact on particles with failed $\mathrm{SiC}$ ). DLBL of these compacts showed a moderate amount of uranium in the initial pre-burn leaching that could have been released through intact $\mathrm{SiC}$, but not enough uranium to indicate exposed kernels, verifying the expectation from the lack of ${ }^{85} \mathrm{Kr}$ release during safety testing that there was no failed TRISO. However, after a decrease in uranium from the first to second pre-burn leach, there was an increase in the amount of uranium detected in the rinse solutions collected after the pre-burn leaching; this indicated that a kernel may have been exposed during this part of the DLBL procedure. The amount of uranium collected suggests that one particle from Compact 5-1-3 and two particles from Compact 3-2-3 may have been damaged by the analysis process resulting in kernel exposure (probably through fracture of the $\mathrm{OPyC}$ ); this is discussed further in the section on the enumeration of particles with failed $\mathrm{SiC}$.

DLBL of as-irradiated compacts typically detects a higher inventory fraction of exposed silver and palladium than any other element. Table 3 shows that exposed ${ }^{110 \mathrm{~m}} \mathrm{Ag}$ and ${ }^{105} \mathrm{Pd}$ in these safety-tested compacts was below the detection limit in most cases. This is consistent with the conclusion from the safety test release data that silver and palladium in the matrix and $\mathrm{OPyC}$ (outside of intact $\mathrm{SiC}$ ) is diffusing out of the compacts at $1600-1800^{\circ} \mathrm{C}$. 
Table 3. Isotopes detected at various stages of DLBL analysis

\begin{tabular}{|c|c|c|c|c|c|c|c|c|c|c|c|c|}
\hline \multirow[b]{2}{*}{ Isotope } & \multirow{2}{*}{$\begin{array}{c}\text { Possible } \\
\text { Background } \\
\text { (upper limit) }\end{array}$} & \multicolumn{3}{|c|}{ Compact 5-3-3 $\left(1600^{\circ} \mathrm{C}\right)$} & \multicolumn{4}{|c|}{ Compact 5-1-3 $\left(1800^{\circ} \mathrm{C}\right)$} & \multicolumn{4}{|c|}{ Compact 3-2-3 $\left(1800^{\circ} \mathrm{C}\right)$} \\
\hline & & pre-burn & $\begin{array}{l}\text { rinse after } \\
\text { pre-burn }\end{array}$ & $\begin{array}{l}\text { combined } \\
\text { post-burn }\end{array}$ & pre-burn & $\begin{array}{l}\text { rinse after } \\
\text { pre-burn }\end{array}$ & $\begin{array}{c}\text { matrix } \\
\text { post-burn }\end{array}$ & $\begin{array}{c}\text { particle } \\
\text { post-burn }\end{array}$ & pre-burn & $\begin{array}{l}\text { rinse after } \\
\text { pre-burn }\end{array}$ & $\begin{array}{l}\text { matrix } \\
\text { post-burn }\end{array}$ & $\begin{array}{c}\text { particle } \\
\text { post-burn }\end{array}$ \\
\hline${ }^{90} \mathrm{Sr}$ & $\begin{array}{c}5 \mathrm{E}-7 \\
(0.002)\end{array}$ & $\begin{array}{c}3.17 \mathrm{E}-4 \\
(1.31)\end{array}$ & $\begin{array}{c}1.88 \mathrm{E}-6 \\
(0.008)\end{array}$ & $\begin{array}{c}3.43 \mathrm{E}-4 \\
(1.42)\end{array}$ & $\begin{array}{c}1.58 \mathrm{E}-4 \\
(0.65)\end{array}$ & $\begin{array}{c}4.00 \mathrm{E}-6 \\
(0.017)\end{array}$ & $\begin{array}{c}3.77 \mathrm{E}-5 \\
(0.16)\end{array}$ & $\begin{array}{c}3.51 \mathrm{E}-4 \\
(1.46)\end{array}$ & $\begin{array}{c}4.73 \mathrm{E}-4 \\
(1.96)\end{array}$ & $\begin{array}{c}7.53 \mathrm{E}-5 \\
(0.31)\end{array}$ & $\begin{array}{c}1.64 \mathrm{E}-4 \\
(0.68)\end{array}$ & $\begin{array}{c}3.09 \mathrm{E}-4 \\
(1.28)\end{array}$ \\
\hline${ }^{105} \mathrm{Pd}$ & $\begin{array}{l}3 \mathrm{E}-4 \\
(1.2)\end{array}$ & $\begin{array}{c}1.10 \mathrm{E}-4 \\
(0.45)\end{array}$ & $\begin{array}{c}<3.13 \mathrm{E}-5 \\
(<0.13)\end{array}$ & $\begin{array}{c}2.80 \mathrm{E}-5 \\
(0.12)\end{array}$ & $\begin{array}{c}3.03 \mathrm{E}-5 \\
(0.13)\end{array}$ & $\begin{array}{c}<2.50 \mathrm{E}-5 \\
(<0.10)\end{array}$ & $\begin{array}{c}<1.36 \mathrm{E}-3 \\
(<5.65)\end{array}$ & $\begin{array}{c}2.00 \mathrm{E}-4 \\
(0.83)\end{array}$ & $\begin{array}{c}<4.23 \mathrm{E}-5 \\
(<0.18)\end{array}$ & $\begin{array}{c}<1.39 \mathrm{E}-3 \\
(<5.77)\end{array}$ & $\begin{array}{c}<4.81 \mathrm{E}-4 \\
(<1.99)\end{array}$ & $\begin{array}{c}1.71 \mathrm{E}-4 \\
(0.71)\end{array}$ \\
\hline${ }^{106} \mathrm{Ru}$ & $\begin{array}{c}4 \mathrm{E}-7 \\
(0.002)\end{array}$ & $\begin{array}{l}1.48 \mathrm{E}-6 \\
(0.006)\end{array}$ & $\begin{array}{l}<1.12 \mathrm{E}-6 \\
(<0.005)\end{array}$ & $\begin{array}{c}9.59 \mathrm{E}-7 \\
(0.004)\end{array}$ & $\begin{array}{c}2.49 \mathrm{E}-6 \\
(0.010)\end{array}$ & $\begin{array}{c}8.92 \mathrm{E}-6 \\
(0.04)\end{array}$ & $\begin{array}{c}9.89 \mathrm{E}-5 \\
(0.41)\end{array}$ & $\begin{array}{c}<2.08 \mathrm{E}-5 \\
(<0.09)\end{array}$ & $\begin{array}{l}<4.13 \mathrm{E}-6 \\
(<0.017)\end{array}$ & $\begin{array}{c}5.20 \mathrm{E}-5 \\
(0.22)\end{array}$ & $\begin{array}{c}1.75 \mathrm{E}-4 \\
(0.73)\end{array}$ & $\begin{array}{c}<1.93 \mathrm{E}-5 \\
(<0.08)\end{array}$ \\
\hline${ }^{110 \mathrm{~m}} \mathrm{Ag}$ & $\begin{array}{l}<5 \mathrm{E}-5 \\
(<0.2)\end{array}$ & $\begin{array}{c}2.76 \mathrm{E}-4 \\
(1.15)\end{array}$ & $\begin{array}{c}<1.18 \mathrm{E}-4 \\
(<0.49)\end{array}$ & $\begin{array}{c}2.25 \mathrm{E}-4 \\
(0.93)\end{array}$ & $\begin{array}{c}<4.28 \mathrm{E}-4 \\
(<1.78)\end{array}$ & $\begin{array}{c}<1.51 \mathrm{E}-4 \\
(<0.63)\end{array}$ & $\begin{array}{c}<3.66 \mathrm{E}-4 \\
(<1.52)\end{array}$ & $\begin{array}{c}<1.79 \mathrm{E}-3 \\
(<7.44)\end{array}$ & $\begin{array}{c}<4.84 \mathrm{E}-4 \\
(<2.01)\end{array}$ & $\begin{array}{c}<3.08 \mathrm{E}-4 \\
(<1.28)\end{array}$ & $\begin{array}{c}<5.33 \mathrm{E}-4 \\
(<2.21)\end{array}$ & $\begin{array}{c}<1.61 \mathrm{E}-3 \\
(<6.68)\end{array}$ \\
\hline${ }^{125} \mathrm{Sb}$ & $\begin{array}{c}1 \mathrm{E}-6 \\
(0.004)\end{array}$ & $\begin{array}{c}<5.98 \mathrm{E}-6 \\
(<0.02)\end{array}$ & $\begin{array}{l}<2.90 \mathrm{E}-6 \\
(<0.012)\end{array}$ & $\begin{array}{c}<1.06 \mathrm{E}-5 \\
(<0.04)\end{array}$ & $\begin{array}{l}<6.75 \mathrm{E}-7 \\
(<0.003)\end{array}$ & $\begin{array}{c}1.38 \mathrm{E}-6 \\
(0.006)\end{array}$ & $\begin{array}{c}1.23 \mathrm{E}-5 \\
(0.05)\end{array}$ & $\begin{array}{c}6.98 \mathrm{E}-6 \\
(0.03)\end{array}$ & $\begin{array}{c}<9.61 \mathrm{E}-6 \\
(<0.04)\end{array}$ & $\begin{array}{c}3.34 \mathrm{E}-5 \\
(0.14)\end{array}$ & $\begin{array}{c}2.07 \mathrm{E}-4 \\
(0.86)\end{array}$ & $\begin{array}{c}<4.58 \mathrm{E}-5 \\
(<0.19)\end{array}$ \\
\hline${ }^{134} \mathrm{Cs}$ & $\begin{array}{c}2 \mathrm{E}-7 \\
(0.0008)\end{array}$ & $\begin{array}{l}3.72 \mathrm{E}-7 \\
(0.0015)\end{array}$ & $\begin{array}{c}7.85 \mathrm{E}-8 \\
(0.0003)\end{array}$ & $\begin{array}{c}2.53 \mathrm{E}-6 \\
(0.010)\end{array}$ & $\begin{array}{c}6.92 \mathrm{E}-6 \\
(0.03)\end{array}$ & $\begin{array}{c}2.11 \mathrm{E}-6 \\
(0.009)\end{array}$ & $\begin{array}{c}1.50 \mathrm{E}-5 \\
(0.06)\end{array}$ & $\begin{array}{c}5.36 \mathrm{E}-4 \\
(2.23)\end{array}$ & $\begin{array}{c}9.28 \mathrm{E}-6 \\
(0.04)\end{array}$ & $\begin{array}{c}1.45 \mathrm{E}-5 \\
(0.06)\end{array}$ & $\begin{array}{c}5.69 \mathrm{E}-5 \\
(0.24)\end{array}$ & $\begin{array}{c}6.02 \mathrm{E}-4 \\
(2.49)\end{array}$ \\
\hline${ }^{137} \mathrm{Cs}$ & $\begin{array}{c}6 \mathrm{E}-7 \\
(0.002)\end{array}$ & $\begin{array}{l}1.76 \mathrm{E}-6 \\
(0.007)\end{array}$ & $\begin{array}{c}6.84 \mathrm{E}-7 \\
(0.003)\end{array}$ & $\begin{array}{l}4.41 \mathrm{E}-6 \\
(0.018)\end{array}$ & $\begin{array}{c}9.95 \mathrm{E}-6 \\
(0.04)\end{array}$ & $\begin{array}{c}3.43 \mathrm{E}-6 \\
(0.014)\end{array}$ & $\begin{array}{c}2.34 \mathrm{E}-5 \\
(0.10)\end{array}$ & $\begin{array}{c}6.04 \mathrm{E}-4 \\
(2.50)\end{array}$ & $\begin{array}{c}1.11 \mathrm{E}-5 \\
(0.05)\end{array}$ & $\begin{array}{c}1.80 \mathrm{E}-5 \\
(0.07)\end{array}$ & $\begin{array}{c}6.87 \mathrm{E}-5 \\
(0.28)\end{array}$ & $\begin{array}{c}6.82 \mathrm{E}-4 \\
(2.83)\end{array}$ \\
\hline${ }^{144} \mathrm{Ce}$ & $\begin{array}{c}5 \mathrm{E}-7 \\
(0.002)\end{array}$ & $\begin{array}{c}1.01 \mathrm{E}-4 \\
(0.42)\end{array}$ & $\begin{array}{c}2.03 \mathrm{E}-6 \\
(0.008)\end{array}$ & $\begin{array}{c}3.70 \mathrm{E}-4 \\
(1.54)\end{array}$ & $\begin{array}{c}9.79 \mathrm{E}-4 \\
(4.06)\end{array}$ & $\begin{array}{c}1.04 \mathrm{E}-4 \\
(0.43)\end{array}$ & $\begin{array}{c}6.16 \mathrm{E}-4 \\
(2.56)\end{array}$ & $\begin{array}{c}2.03 \mathrm{E}-3 \\
(8.42)\end{array}$ & $\begin{array}{c}3.82 \mathrm{E}-4 \\
(1.58)\end{array}$ & $\begin{array}{c}3.20 \mathrm{E}-4 \\
(1.32)\end{array}$ & $\begin{array}{c}2.98 \mathrm{E}-4 \\
(1.23)\end{array}$ & $\begin{array}{c}4.44 \mathrm{E}-4 \\
(1.84)\end{array}$ \\
\hline${ }^{154} \mathrm{Eu}$ & $\begin{array}{c}3 \mathrm{E}-6 \\
(0.01)\end{array}$ & $\begin{array}{c}4.96 \mathrm{E}-4 \\
(2.06)\end{array}$ & $\begin{array}{l}<2.59 \mathrm{E}-6 \\
(<0.011)\end{array}$ & $\begin{array}{c}1.37 \mathrm{E}-3 \\
(5.68)\end{array}$ & $\begin{array}{c}1.80 \mathrm{E}-4 \\
(0.75)\end{array}$ & $\begin{array}{c}2.09 \mathrm{E}-6 \\
(0.009)\end{array}$ & $\begin{array}{c}1.31 \mathrm{E}-4 \\
(0.54)\end{array}$ & $\begin{array}{c}4.32 \mathrm{E}-4 \\
(1.79)\end{array}$ & $\begin{array}{c}4.56 \mathrm{E}-4 \\
(1.89)\end{array}$ & $\begin{array}{c}6.58 \mathrm{E}-5 \\
(0.27)\end{array}$ & $\begin{array}{c}3.36 \mathrm{E}-4 \\
(1.39)\end{array}$ & $\begin{array}{c}2.31 \mathrm{E}-4 \\
(0.96)\end{array}$ \\
\hline${ }^{155} \mathrm{Eu}$ & $\begin{array}{l}2 \mathrm{E}-6 \\
(0.01)\end{array}$ & $\begin{array}{c}5.41 \mathrm{E}-4 \\
(2.24)\end{array}$ & $\begin{array}{c}2.66 \mathrm{E}-6 \\
(0.011)\end{array}$ & $\begin{array}{c}1.50 \mathrm{E}-3 \\
(6.23)\end{array}$ & $\begin{array}{c}1.49 \mathrm{E}-4 \\
(0.62)\end{array}$ & $\begin{array}{l}<2.83 \mathrm{E}-6 \\
(<0.012)\end{array}$ & $\begin{array}{c}1.06 \mathrm{E}-4 \\
(0.44)\end{array}$ & $\begin{array}{c}3.79 \mathrm{E}-4 \\
(1.57)\end{array}$ & $\begin{array}{c}5.19 \mathrm{E}-4 \\
(2.15)\end{array}$ & $\begin{array}{c}6.11 \mathrm{E}-5 \\
(0.25)\end{array}$ & $\begin{array}{c}3.59 \mathrm{E}-4 \\
(1.49)\end{array}$ & $\begin{array}{c}2.52 \mathrm{E}-4 \\
(1.04)\end{array}$ \\
\hline${ }^{235} \mathrm{U}$ & $\begin{array}{l}2 \mathrm{E}-6 \\
(0.01)\end{array}$ & $\begin{array}{l}6.47 \mathrm{E}-6 \\
(0.027)\end{array}$ & $\begin{array}{l}3.87 \mathrm{E}-7 \\
(0.0016)\end{array}$ & $\begin{array}{l}1.68 \mathrm{E}-5 \\
(0.070)\end{array}$ & $\begin{array}{c}7.99 \mathrm{E}-5 \\
(0.33)\end{array}$ & $\begin{array}{c}1.89 \mathrm{E}-4 \\
(0.79)\end{array}$ & $\begin{array}{c}3.26 \mathrm{E}-5 \\
(0.14)\end{array}$ & $\begin{array}{c}9.76 \mathrm{E}-4 \\
(4.05)\end{array}$ & $\begin{array}{c}9.03 \mathrm{E}-5 \\
(0.37)\end{array}$ & $\begin{array}{c}2.26 \mathrm{E}-4 \\
(0.94)\end{array}$ & $\begin{array}{c}1.42 \mathrm{E}-4 \\
(0.59)\end{array}$ & $\begin{array}{c}4.90 \mathrm{E}-4 \\
(2.03)\end{array}$ \\
\hline${ }^{238} \mathrm{U}$ & $\begin{array}{l}3 \mathrm{E}-6 \\
(0.01)\end{array}$ & $\begin{array}{l}7.71 \mathrm{E}-6 \\
(0.032)\end{array}$ & $\begin{array}{l}1.20 \mathrm{E}-6 \\
(0.005)\end{array}$ & $\begin{array}{c}2.01 \mathrm{E}-5 \\
(0.083)\end{array}$ & $\begin{array}{c}8.73 \mathrm{E}-5 \\
(0.36)\end{array}$ & $\begin{array}{c}1.79 \mathrm{E}-4 \\
(0.74)\end{array}$ & $\begin{array}{c}4.80 \mathrm{E}-5 \\
(0.20)\end{array}$ & $\begin{array}{c}1.11 \mathrm{E}-3 \\
(4.59)\end{array}$ & $\begin{array}{c}1.17 \mathrm{E}-4 \\
(0.48)\end{array}$ & $\begin{array}{c}3.07 \mathrm{E}-4 \\
(1.27)\end{array}$ & $\begin{array}{c}1.46 \mathrm{E}-4 \\
(0.60)\end{array}$ & $\begin{array}{c}6.01 \mathrm{E}-4 \\
(2.49)\end{array}$ \\
\hline${ }^{239} \mathrm{Pu}$ & $\begin{array}{l}2 \mathrm{E}-6 \\
(0.01)\end{array}$ & $\begin{array}{c}2.42 \mathrm{E}-5 \\
(0.10)\end{array}$ & $\begin{array}{c}8.56 \mathrm{E}-7 \\
(0.004)\end{array}$ & $\begin{array}{c}9.35 \mathrm{E}-5 \\
(0.39)\end{array}$ & $\begin{array}{c}2.61 \mathrm{E}-4 \\
(1.08)\end{array}$ & $\begin{array}{c}7.08 \mathrm{E}-6 \\
(0.03)\end{array}$ & $\begin{array}{c}1.40 \mathrm{E}-4 \\
(0.58)\end{array}$ & $\begin{array}{c}8.18 \mathrm{E}-4 \\
(3.39)\end{array}$ & $\begin{array}{c}4.89 \mathrm{E}-4 \\
(2.03)\end{array}$ & $\begin{array}{c}1.39 \mathrm{E}-4 \\
(0.58)\end{array}$ & $\begin{array}{c}4.54 \mathrm{E}-4 \\
(1.88)\end{array}$ & $\begin{array}{c}7.64 \mathrm{E}-4 \\
(3.17)\end{array}$ \\
\hline${ }^{240} \mathrm{Pu}$ & $\begin{array}{c}3 \mathrm{E}-6 \\
(0.01)\end{array}$ & $\begin{array}{c}5.18 \mathrm{E}-5 \\
(0.22)\end{array}$ & $\begin{array}{l}<7.24 \mathrm{E}-7 \\
(<0.003)\end{array}$ & $\begin{array}{c}2.15 \mathrm{E}-4 \\
(0.89)\end{array}$ & $\begin{array}{c}4.40 \mathrm{E}-4 \\
(1.82)\end{array}$ & $\begin{array}{c}6.46 \mathrm{E}-6 \\
(0.03)\end{array}$ & $\begin{array}{c}1.99 \mathrm{E}-4 \\
(0.83)\end{array}$ & $\begin{array}{c}9.29 \mathrm{E}-4 \\
(3.86)\end{array}$ & $\begin{array}{c}5.21 \mathrm{E}-4 \\
(2.16)\end{array}$ & $\begin{array}{c}1.46 \mathrm{E}-4 \\
(0.60)\end{array}$ & $\begin{array}{c}4.81 \mathrm{E}-4 \\
(2.00)\end{array}$ & $\begin{array}{c}8.11 \mathrm{E}-4 \\
(3.36)\end{array}$ \\
\hline
\end{tabular}

Values are reported as the fraction of compact inventory and the equivalent number of exposed kernels (in parentheses).

$"<"$ indicates the measured signal was below a minimum detectable limit.

Numbers in gray are below estimated upper limits for possible background from hot cell contamination, determined by analysis of acid rinses as described in [Hunn et al. 2013-1]. 
The amount of ${ }^{90} \mathrm{Sr}$ and ${ }^{154} \mathrm{Eu}$ detected by DLBL to be outside of intact SiC in Compact 5-3-3 (Table 3) was 2.2-2.3 times larger than the amounts released from the compact during the safety test at $1600^{\circ} \mathrm{C}$ (Table 2). Table 4 shows how the ${ }^{90} \mathrm{Sr}$ and ${ }^{154} \mathrm{Eu}$ outside of the $\mathrm{SiC}$ layer was distributed at the end of each safety test. At $1600^{\circ} \mathrm{C},{ }^{90} \mathrm{Sr}$ and ${ }^{154} \mathrm{Eu}$ appeared to move slowly from the compact carbonaceous OPyC and matrix, through the graphite holder and eventually to the deposition cups, with most staying in the compact. At $1800^{\circ} \mathrm{C},{ }^{90} \mathrm{Sr}$ and ${ }^{154} \mathrm{Eu}$ were not as strongly retained by the carbonaceous materials and a much higher fraction reached the deposition cups.

Table 4. Distribution of europium (and strontium in parentheses) outside of $\mathrm{SiC}$

\begin{tabular}{|c|c|c|c|}
\hline Location & Compact 5-3-3 at $1600^{\circ} \mathrm{C}$ & Compact $5-1-3$ at $1800^{\circ} \mathrm{C}$ & Compact $3-2-3$ at $1800^{\circ} \mathrm{C}$ \\
\hline Compact matrix/OPyC & $(68.9 \%)$ & $(1.6 \%)$ & $(6.4 \%)$ \\
\hline Graphite holder & $18.3 \% \quad(20.0 \%)$ & $2.5 \% \quad(1.4 \%)$ & $(10.3 \%)$ \\
\hline Tantalum can & $(0.4 \%)$ & $(0.7 \%)$ & $(6.2 \%)$ \\
\hline Deposition cups & $(10.7 \%)$ & $(96.3 \%)$ & $(77.0 \%)$ \\
\hline
\end{tabular}

\section{IMGA RESULTS}

After deconsolidation of Compacts 5-1-3 and 3-2-3, an IMGA survey of all available particles was performed using a 100-120-second counting time to look for individual particles that may have lost a significant fraction of cesium and been responsible for the observed cesium release in the CCCTF (Figure 5). Figure 6 and Figure 7 are histograms of the individual-particle ${ }^{137} \mathrm{Cs}$ content, plotted as the ratio of the measured versus calculated inventory and adjusted for particle-to-particle variation in fissionable material and burn-up using the measured ${ }^{144} \mathrm{Ce}$ activity; this standard approach for presenting IMGA results is described elsewhere [Hunn et al. 2013-1]. The symmetric distributions around a measured to calculated ratio $(\mathrm{M} / \mathrm{C})$ of one indicate that the typical particle retained ${ }^{137} \mathrm{Cs}$ well, and the calculated inventories appear to be accurate to within a few percent. Compact 5-1-3 had five particles with abnormally low ${ }^{137} \mathrm{Cs}$ retention (relative to ${ }^{144} \mathrm{Ce}$ ) and Compact 3-2-3 had nine; these can be seen populating bins to the left of the main distributions $(\mathrm{M} / \mathrm{C}<0.8)$. These low-cesium particles were automatically sorted out during the IMGA survey and labeled as specially-selected particle (SP) for further analysis.

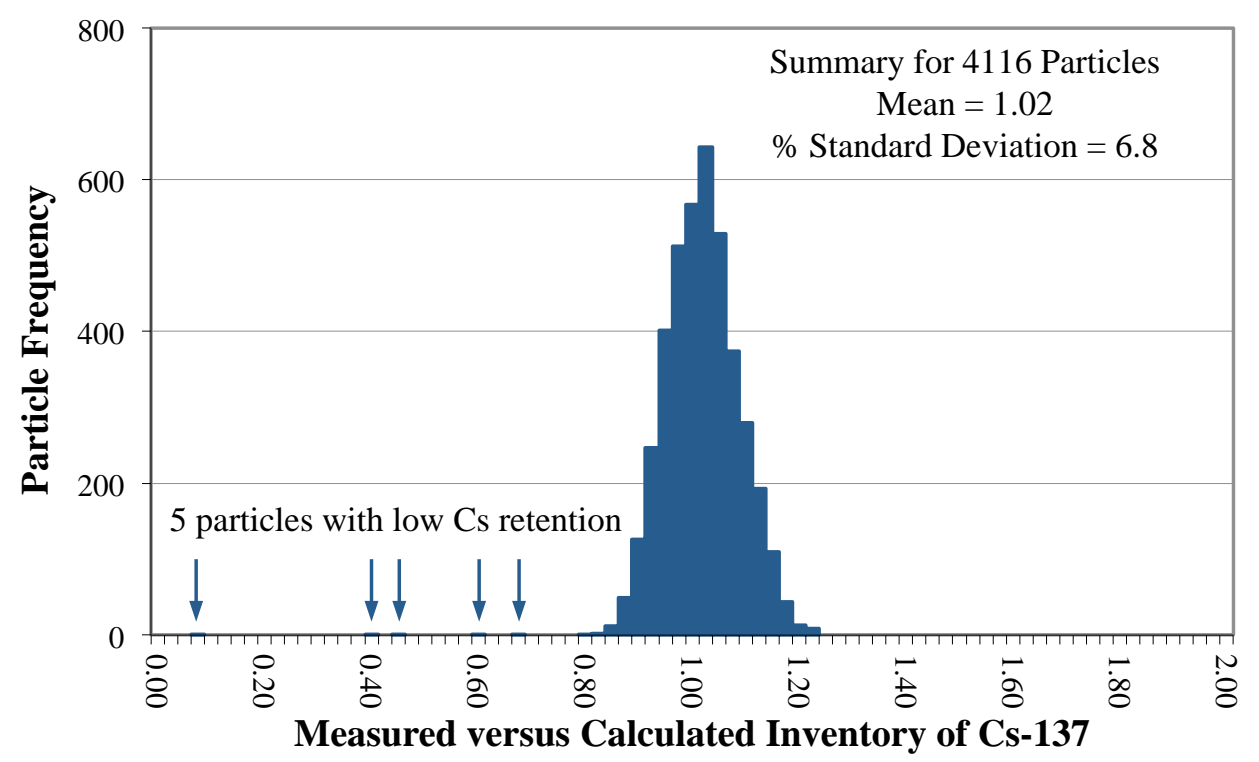

Figure 6. Estimated fraction of ${ }^{137} \mathrm{Cs}$ retained in particles from Compact 5-1-3, based on calculated inventory and adjusted for variation in fissionable material and burn-up using the measured ${ }^{144} \mathrm{Ce}$ activity. 


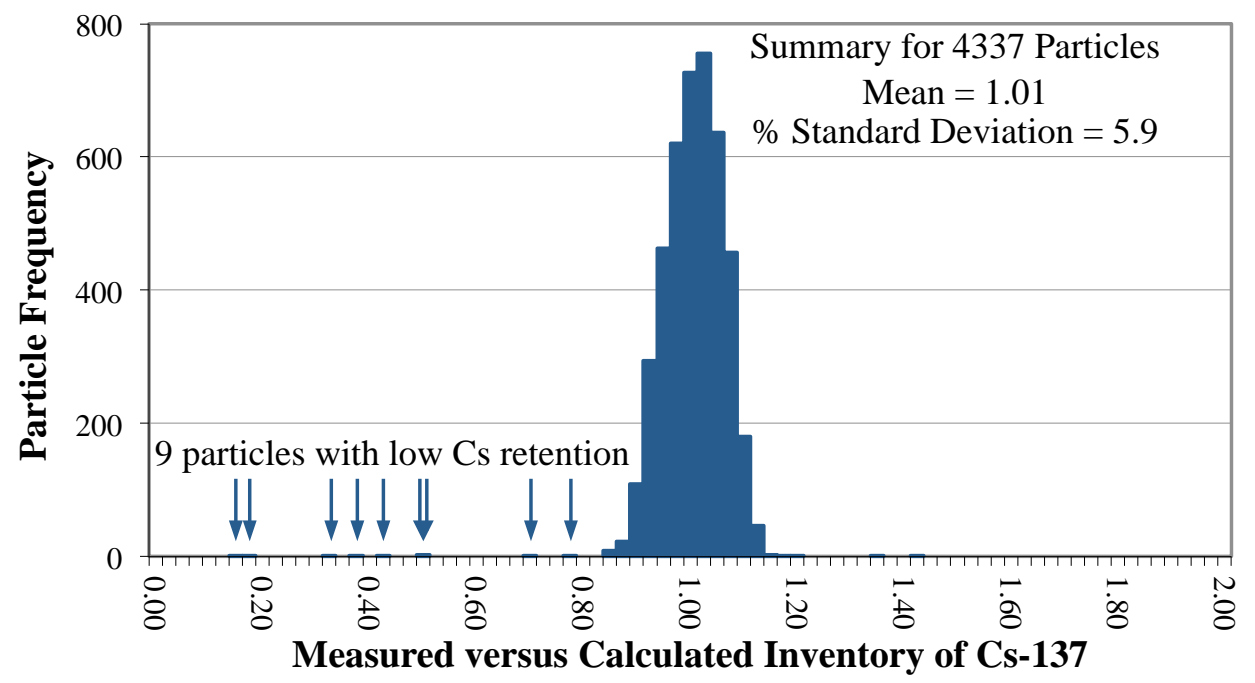

Figure 7. Estimated fraction of ${ }^{137} \mathrm{Cs}$ retained in particles from Compact 3-2-3, based on calculated inventory and adjusted for variation in fissionable material and burn-up using the measured ${ }^{144} \mathrm{Ce}$ activity.

Prior to IMGA survey, all the particles recovered from each compact were imaged and counted. The total number of individual particles recovered from Compact 5-1-3 was 4140, which is within two standard deviations of the average Variant 1 particle loading of $4150 \pm 5$ determined as part of the quality control (QC) inspection for uranium dispersion in particles from twelve as-fabricated compacts [Hunn, Montgomery, and Pappano 2006-2]. Only 4116 Compact 5-1-3 particles were gamma scanned with IMGA, indicating 23 were dropped during particle handling. (Loss of particles during IMGA handling occurs when particles cling to the particle attached to the end of the vacuum needle and subsequently drop off between the storage vials and gamma counting station.)

The total number of individual particles recovered from Compact 3-2-3 was 4349, which is abnormally high compared to the QC-measured average of $4145 \pm 4$ particles per AGR-1 Baseline compact [Hunn, Montgomery, and Pappano 2006-1]. There were 4337 Compact 3-2-3 particles gamma scanned with IMGA, indicating 12 were dropped during particle handling. A likely explanation for the extra 200 particles in Compact 3-2-3 is related to the fact that this was one of the last Baseline compacts fabricated (number 82 of 84 ). AGR-1 compacting charges were weighed out to a target value predicted to be equivalent to the desired number of particles based on the average overcoated particle weight. During AGR-1 fabrication, compacting charges were poured out of a container and it is likely that some sizedependent stratification occurred, such that the population of smaller and lighter overcoated particles was concentrated at the bottom of the container. This stratification would result in more particles (with less overcoat) going into the last few compacts fabricated.

The two compacts that were fabricated after Compact 3-2-3 (LEU01-46T-Z04 and LEU01-46T-Z11) were not available for additional analysis, having been used with four other compacts for uranium contamination analysis during QC testing [Hunn, Montgomery, and Pappano 2006-1]. However, the residual weight of the particles in that sample after leaching was unusually high and would be consistent with those two compacts each having $>200$ extra particles. The compact fabricated immediately before Compact 3-2-3 (LEU01-46T-Z29) was available for additional analysis. This compact was burned in air at $750^{\circ} \mathrm{C}$ for 60 hours to recover the individual particles; there were 4237 particles in the compact. This appears to confirm the hypothesis that the particle count was increasing at the end of the AGR-1 Baseline compact fabrication campaign. Additional evidence that Compact 3-2-3 had an above average number of particles can be seen in the gamma scanning data for the twelve compacts in Capsule 3 (Table 5); Compact 3-2-3 exhibited an above average activity at the end of irradiation that is consistent with an above average particle loading. (AGR-2 compacting charges were obtained using a rotary riffler to insure a more random and uniform distribution of the overcoated particles in each compact.) 
Table 5. Ratio of measured [Harp 2013] to calculated [Sterbentz 2013] activity of various gammaemitting isotopes in Capsule 3 compacts showing unusually high activity in Compact 3-2-3

\begin{tabular}{|c||c|c|c|c|c|c|}
\hline Compact ID & ${ }^{{ }^{106}} \mathbf{R u}$ & ${ }^{\mathbf{1 2 5}} \mathbf{S b}$ & ${ }^{\mathbf{1 3 4}} \mathbf{C s}$ & ${ }^{\mathbf{1 3 7}} \mathbf{C s}$ & ${ }^{\mathbf{1 4 4}} \mathbf{C e}$ & ${ }^{\mathbf{1 5 4}} \mathbf{E u}$ \\
\hline \hline 343 & 0.957 & 0.668 & 1.013 & 1.002 & 0.979 & 0.849 \\
\hline 333 & 0.956 & 0.674 & 1.004 & 0.994 & 0.966 & 0.844 \\
\hline 323 & 0.999 & 0.714 & 1.055 & 1.049 & 1.021 & 0.890 \\
\hline 343 & 0.970 & 0.657 & 1.019 & 1.005 & 0.976 & 0.830 \\
\hline 332 & 0.961 & 0.667 & 0.971 & 0.979 & 1.016 & 0.804 \\
\hline 322 & 0.948 & 0.687 & 0.941 & 0.961 & 1.004 & 0.789 \\
\hline 312 & 0.915 & 0.663 & 0.910 & 0.929 & 0.970 & 0.770 \\
\hline 341 & 0.894 & 0.655 & 0.923 & 0.923 & 0.943 & 0.770 \\
\hline 331 & 0.875 & 0.622 & 0.904 & 0.924 & 0.916 & 0.776 \\
\hline 321 & 0.926 & 0.667 & 0.947 & 0.974 & 0.977 & 0.804 \\
\hline 311 & 0.901 & 0.621 & 0.922 & 0.957 & 0.962 & 0.791 \\
\hline
\end{tabular}

Specially-selected particles from Compacts 5-1-3 and 3-2-3 (identified with IMGA to have relatively low ${ }^{137} \mathrm{Cs}$ or ${ }^{144} \mathrm{Ce}$ inventories), along with a sample of $40-60$ randomly-selected particles (RS) from each of the three compacts were loaded into individual vials and subjected to 5-hour gamma scanning. This longer scan time provided better quantitative analysis of the cesium and cerium content, and also allowed for analysis of other lower activity gamma-emitting isotopes, such as silver and europium. By handling particles in separate vials, the individual identity of each particle was maintained throughout the remainder of the PIE. Table 6 shows the measured activities for various isotopes retained in the randomly-selected particles from Compact 5-3-3. All activities are decay-corrected to one day after the end of irradiation (11/07/2009 at 1200 GMT). The measured inventories can be compared to the calculated inventories for an average particle in each compact (also provided in the table); values in parentheses are the ratios of the measured inventories to the average calculated inventories, but these ratios do not include the adjustment for variation in fissile material or burnup used in the IMGA histograms. The range in average activity for ${ }^{110 \mathrm{~m}} \mathrm{Ag}$ was calculated by summing the particles with undetectable ${ }^{110 \mathrm{~m}} \mathrm{Ag}$ as containing either zero silver or as high as the detection limit. In the randomlyselected particles, ${ }^{110 \mathrm{~m}} \mathrm{Ag}$ was the only isotope that was measurably below the expected value due to release through intact $\mathrm{SiC}$ (most likely during the irradiation test). The measured to calculated ratios for ${ }^{125} \mathrm{Sb}$ and ${ }^{154} \mathrm{Eu}$ were uniformly low (0.66-0.68 and $0.80-0.83$, respectively), but this is due to a positive bias in the calculated inventories and does not represent measurable loss of these isotopes from the particles [Harp 2013]. The average activities for ${ }^{106} \mathrm{Ru},{ }^{134} \mathrm{Cs},{ }^{137} \mathrm{Cs}$, and ${ }^{144} \mathrm{Ce}$ in the randomly-selected particles were close to the calculated values.

Table 6. Radioactive isotopes detected in particles from Compact 5-3-3

\begin{tabular}{|c||c|c|c|c|c|c|c|}
\hline \multicolumn{1}{|c||}{} & \multicolumn{6}{c|}{ Activity of various gamma-emitting isotopes in Bq/particle } \\
\cline { 2 - 9 } & ${ }^{\mathbf{1 0 6}} \mathbf{R u}$ & ${ }^{110 \mathbf{m}} \mathbf{A g}$ & ${ }^{\mathbf{1 2 5}} \mathbf{S b}$ & ${ }^{134} \mathbf{C s}$ & ${ }^{137} \mathbf{C s}$ & ${ }^{144} \mathbf{C e}$ & ${ }^{154} \mathbf{E u}$ \\
\hline \hline $\begin{array}{c}\text { Calculated inventory for an } \\
\text { average particle from 5-3-3 }\end{array}$ & $1.29 \mathrm{E} 7$ & $4.70 \mathrm{E} 4$ & $3.10 \mathrm{E} 5$ & $4.87 \mathrm{E} 6$ & $4.21 \mathrm{E} 6$ & $5.27 \mathrm{E} 7$ & $1.58 \mathrm{E} 5$ \\
\hline $\begin{array}{c}\text { Average measured inventory } \\
\text { of 45 random particles }\end{array}$ & $\begin{array}{c}1.21 \mathrm{E} 7 \\
(0.94)\end{array}$ & $\begin{array}{c}2.4-2.8 \mathrm{E} 4 \\
(0.51-0.59)\end{array}$ & $\begin{array}{c}2.05 \mathrm{E} 5 \\
(0.66)\end{array}$ & $\begin{array}{c}4.64 \mathrm{E} 6 \\
(0.95)\end{array}$ & $\begin{array}{c}4.09 \mathrm{E} 6 \\
(0.97)\end{array}$ & $\begin{array}{c}5.17 \mathrm{E} 7 \\
(0.98)\end{array}$ & $\begin{array}{c}1.26 \mathrm{E} 5 \\
(0.80)\end{array}$ \\
\hline $\begin{array}{c}\text { Percent standard deviation in } \\
\text { average measured inventory }\end{array}$ & 8.62 & & 7.32 & 8.52 & 7.21 & 7.77 & 8.05 \\
\hline
\end{tabular}

Values in parentheses are the measured/calculated ratios; highlighted cells indicate a measurable isotopic release. 
Table 7 shows the measured activities for various isotopes retained in the specially-selected particles and the average measured activities of the randomly-selected particles from Compact 5-1-3. Similar to Compact 5-3-3, ${ }^{110 \mathrm{~m}} \mathrm{Ag}$ was the only isotope in the randomly-selected particles that was measurably below the expected average value due to release through intact $\mathrm{SiC}$; all other isotopes were within the measurement uncertainty of the expected average. Particle $513-\mathrm{SP} 01$ had a normal ${ }^{137} \mathrm{Cs} /{ }^{144} \mathrm{Ce}$ ratio, but both isotopes were only about one-quarter of the expected inventory. In conjunction, the ${ }^{106} \mathrm{Ru},{ }^{110 \mathrm{~m}} \mathrm{Ag}$, ${ }^{125} \mathrm{Sb}$, and ${ }^{154} \mathrm{Eu}$ inventories were high, relative to the ${ }^{144} \mathrm{Ce}$. This has been observed in other compacts and appears to be related to an abnormally low ${ }^{235} \mathrm{U}$ enrichment [Hunn et al. 2013-1, page 36]. Particle 513SP02 also had a normal ${ }^{137} \mathrm{Cs} /{ }^{144} \mathrm{Ce}$ ratio but both isotopes were only about one-half of the expected inventory; in conjunction, all other isotopes were also about one-half of their expected values. X-ray imaging, discussed in the next section, showed that this particle simply had an undersized kernel. All of the other specially-selected particles listed in Table 7 (Particles 513-SP03-SP07) had below-average cesium inventories due to cesium loss during safety testing (note the normal ${ }^{144} \mathrm{Ce}$ inventories); $\mathrm{x}$-ray imaging confirmed that each of these particles had a failed SiC layer. In addition to cesium release, these particles also lost varying amounts of silver and europium (presumably due to the failed $\mathrm{SiC}$ ). Particle 513-SP06 was unique in that it appeared to also lose some ${ }^{106} \mathrm{Ru}$ and ${ }^{125} \mathrm{Sb}$.

Table 7. Radioactive isotopes detected in particles from Compact 5-1-3

\begin{tabular}{|c|c|c|c|c|c|c|c|}
\hline & \multicolumn{7}{|c|}{ Activity of select gamma-emitting isotopes in $\mathrm{Bq} / \mathrm{particle}$} \\
\hline & ${ }^{106} \mathrm{Ru}$ & ${ }^{110 \mathrm{~m}} \mathrm{Ag}$ & ${ }^{125} \mathrm{Sb}$ & ${ }^{134} \mathrm{Cs}$ & ${ }^{137} \mathrm{Cs}$ & ${ }^{144} \mathrm{Ce}$ & ${ }^{154} \mathbf{E u}$ \\
\hline $\begin{array}{l}\text { Calculated inventory for an } \\
\text { average particle from 5-1-3 }\end{array}$ & $1.43 \mathrm{E} 7$ & $5.79 \mathrm{E} 4$ & 3.32E5 & 5.79E6 & 4.49E6 & $5.21 \mathrm{E} 7$ & $1.84 \mathrm{E} 5$ \\
\hline $\begin{array}{l}\text { Average measured inventory } \\
\text { of } 40 \text { random particles }\end{array}$ & $\begin{array}{l}1.42 \mathrm{E} 7 \\
(0.99)\end{array}$ & $\begin{array}{c}4.1-4.4 \mathrm{E} 4 \\
(0.70-0.76)\end{array}$ & $\begin{array}{l}2.25 \mathrm{E} 5 \\
(0.68)\end{array}$ & $\begin{array}{c}6.00 \mathrm{E} 6 \\
(1.04)\end{array}$ & $\begin{array}{l}4.44 \mathrm{E} 6 \\
(0.99)\end{array}$ & $\begin{array}{l}5.14 \mathrm{E} 7 \\
(0.99)\end{array}$ & $\begin{array}{c}1.53 \mathrm{E} 5 \\
(0.83)\end{array}$ \\
\hline $\begin{array}{l}\text { Percent standard deviation in } \\
\text { average measured inventory }\end{array}$ & 11.04 & & 8.15 & 11.92 & 7.72 & 7.10 & 12.14 \\
\hline $\begin{array}{l}\text { Low-cesium particle } \\
\quad(513-\mathrm{SP} 01)\end{array}$ & $\begin{array}{l}1.25 \mathrm{E} 7 \\
(0.88)\end{array}$ & $\begin{array}{l}2.05 \mathrm{E} 4 \\
(0.35)\end{array}$ & $\begin{array}{l}1.20 \mathrm{E} 5 \\
(0.36)\end{array}$ & $\begin{array}{l}1.19 \mathrm{E} 6 \\
(0.20)\end{array}$ & $\begin{array}{l}1.08 \mathrm{E} 6 \\
(0.24)\end{array}$ & $\begin{array}{l}1.19 \mathrm{E} 7 \\
(0.23)\end{array}$ & $\begin{array}{c}5.21 \mathrm{E} 4 \\
(0.28)\end{array}$ \\
\hline $\begin{array}{l}\text { Low-cesium particle } \\
\text { (513-SP02) }\end{array}$ & $\begin{array}{l}7.00 \mathrm{E} 6 \\
(0.49)\end{array}$ & $\begin{array}{c}2.88 \mathrm{E} 4 \\
(0.50)\end{array}$ & $\begin{array}{l}1.12 \mathrm{E} 5 \\
(0.34)\end{array}$ & $\begin{array}{c}2.94 \mathrm{E} 6 \\
(0.51)\end{array}$ & $\begin{array}{c}2.20 \mathrm{E} 6 \\
(0.49)\end{array}$ & $\begin{array}{l}2.72 \mathrm{E} 7 \\
(0.52)\end{array}$ & $\begin{array}{c}7.67 \mathrm{E} 4 \\
(0.42)\end{array}$ \\
\hline $\begin{array}{l}\text { Low-cesium particle } \\
\text { (513-SP03) }\end{array}$ & $\begin{array}{l}1.46 \mathrm{E} 7 \\
(1.02)\end{array}$ & $\begin{array}{l}<5.99 \mathrm{E} 3 \\
(<0.10)\end{array}$ & $\begin{array}{c}2.40 \mathrm{E} 5 \\
(0.72)\end{array}$ & $\begin{array}{l}4.04 \mathrm{E} 5 \\
(0.07)\end{array}$ & $\begin{array}{c}2.81 \mathrm{E} 5 \\
(0.06)\end{array}$ & $\begin{array}{l}5.55 \mathrm{E} 7 \\
(1.06)\end{array}$ & $\begin{array}{c}2.78 \mathrm{E} 3 \\
(0.02)\end{array}$ \\
\hline $\begin{array}{l}\text { Low-cesium particle } \\
\quad(513-\mathrm{SP} 04)\end{array}$ & $\begin{array}{l}1.43 \mathrm{E} 7 \\
(1.00)\end{array}$ & $\begin{array}{l}<8.64 \mathrm{E} 3 \\
(<0.15)\end{array}$ & $\begin{array}{c}2.33 \mathrm{E} 5 \\
(0.70)\end{array}$ & $\begin{array}{c}2.35 \mathrm{E} 6 \\
(0.41)\end{array}$ & $\begin{array}{c}1.96 \mathrm{E} 6 \\
(0.44)\end{array}$ & $\begin{array}{l}5.79 \mathrm{E} 7 \\
(1.11)\end{array}$ & $\begin{array}{c}5.51 \mathrm{E} 4 \\
(0.30)\end{array}$ \\
\hline $\begin{array}{l}\text { Low-cesium particle } \\
\quad(513-\text { SP05) }\end{array}$ & $\begin{array}{l}1.47 \mathrm{E} 7 \\
(1.03)\end{array}$ & $\begin{array}{l}<8.10 \mathrm{E} 3 \\
(<0.14)\end{array}$ & $\begin{array}{c}2.34 \mathrm{E} 5 \\
(0.71)\end{array}$ & $\begin{array}{l}2.67 \mathrm{E} 6 \\
(0.46)\end{array}$ & $\begin{array}{c}1.95 \mathrm{E} 6 \\
(0.44)\end{array}$ & $\begin{array}{l}5.38 \mathrm{E} 7 \\
(1.03)\end{array}$ & $\begin{array}{c}1.18 \mathrm{E} 4 \\
(0.06)\end{array}$ \\
\hline $\begin{array}{l}\text { Low-cesium particle } \\
\text { (513-SP06) }\end{array}$ & $\begin{array}{l}1.19 \mathrm{E} 7 \\
(0.83)\end{array}$ & $\begin{array}{l}1.97 \mathrm{E} 4 \\
(0.34)\end{array}$ & $\begin{array}{l}2.06 \mathrm{E} 5 \\
(0.62)\end{array}$ & $\begin{array}{c}2.97 \mathrm{E} 6 \\
(0.51)\end{array}$ & $\begin{array}{c}2.37 \mathrm{E} 6 \\
(0.53)\end{array}$ & $\begin{array}{l}5.22 \mathrm{E} 7 \\
(1.00)\end{array}$ & $\begin{array}{c}5.50 \mathrm{E} 4 \\
(0.30)\end{array}$ \\
\hline $\begin{array}{l}\text { Low-cesium particle } \\
\text { (513-SP07) }\end{array}$ & $\begin{array}{l}1.47 \mathrm{E} 7 \\
(1.03)\end{array}$ & $\begin{array}{l}2.66 \mathrm{E} 4 \\
(0.46)\end{array}$ & $\begin{array}{c}2.45 \mathrm{E} 5 \\
(0.74)\end{array}$ & $\begin{array}{c}4.26 \mathrm{E} 6 \\
(0.73)\end{array}$ & $\begin{array}{c}3.13 \mathrm{E} 6 \\
(0.70)\end{array}$ & $\begin{array}{l}5.68 \mathrm{E} 7 \\
(1.09)\end{array}$ & $\begin{array}{l}1.30 \mathrm{E} 5 \\
(0.70)\end{array}$ \\
\hline
\end{tabular}

Values in parentheses are the measured/calculated ratios; highlighted cells indicate a measurable isotopic release.

Table 8 shows the measured activities for various isotopes retained in the specially-selected particles and the average measured activities of the randomly-selected particles from Compact 3-2-3. Similar to the other two compacts, ${ }^{110 \mathrm{~m}} \mathrm{Ag}$ was the only isotope in the randomly-selected particles that was measurably below the expected average value due to release through intact $\mathrm{SiC}$; all other isotopes were within the measurement uncertainty of the expected average. Particles 323-SP01-SP08 and SP10 all had below average cesium inventories due to cesium loss during safety testing; $x$-ray imaging, discussed in the next 
section, confirmed that each of these particles had a failed SiC layer. In addition to cesium release, these particles also lost almost all their silver and europium. Particles 323-SP09 and SP11 had slightly-low ${ }^{137} \mathrm{Cs} /{ }^{144} \mathrm{Ce}$ ratios and were in the low-end tail of the main distribution (Figure 7). Particle 323-SP12 also had a slightly-low ${ }^{137} \mathrm{Cs} /{ }^{144} \mathrm{Ce}$ ratio due to above average ${ }^{144} \mathrm{Ce}$. These three particles were isolated during short scanning and analyzed by x-ray. Particles 323-SP11 and SP12 did not exhibit any unusual coating damage beyond fractured buffer, while Particle 323-SP09 also had a cracked IPyC and partially degraded $\mathrm{SiC}$, as discussed in the next section.

Table 8. Radioactive isotopes detected in particles from Compact 3-2-3

\begin{tabular}{|c|c|c|c|c|c|c|c|}
\hline & \multicolumn{7}{|c|}{ Activity of select gamma-emitting isotopes in Bq/particle } \\
\hline & ${ }^{106} \mathrm{Ru}$ & ${ }^{110 \mathrm{~m}} \mathrm{Ag}$ & ${ }^{125} \mathrm{Sb}$ & ${ }^{134} \mathrm{Cs}$ & ${ }^{137} \mathrm{Cs}$ & ${ }^{144} \mathrm{Ce}$ & ${ }^{154} \mathbf{E u}$ \\
\hline $\begin{array}{l}\text { Calculated inventory for an } \\
\text { average particle from 3-2-3 }\end{array}$ & $1.60 \mathrm{E} 7$ & $7.25 \mathrm{E} 4$ & $3.58 \mathrm{E} 5$ & 6.73E6 & 4.76E6 & $5.44 \mathrm{E} 7$ & 2.04E5 \\
\hline $\begin{array}{l}\text { Average measured inventory } \\
\text { of } 60 \text { random particles }\end{array}$ & $\begin{array}{l}1.58 \mathrm{E} 7 \\
(0.98)\end{array}$ & $\begin{array}{c}5.0-5.2 \mathrm{E} 4 \\
(0.69-0.72)\end{array}$ & $\begin{array}{l}2.38 \mathrm{E} 5 \\
(0.66)\end{array}$ & $\begin{array}{c}6.87 \mathrm{E} 6 \\
(1.02)\end{array}$ & $\begin{array}{l}4.71 \mathrm{E} 6 \\
(0.99)\end{array}$ & $\begin{array}{l}5.47 \mathrm{E} 7 \\
(1.00)\end{array}$ & $\begin{array}{c}1.67 \mathrm{E} 5 \\
(0.82)\end{array}$ \\
\hline $\begin{array}{l}\text { Percent standard deviation in } \\
\text { average measured inventory }\end{array}$ & 8.72 & & 6.93 & 7.08 & 6.18 & 6.31 & 14.79 \\
\hline $\begin{array}{l}\text { Low-cesium particle } \\
\quad(323-\mathrm{SP} 01)\end{array}$ & $\begin{array}{l}1.40 \mathrm{E} 7 \\
(0.87)\end{array}$ & $\begin{array}{l}<7.89 \mathrm{E}+03 \\
\quad(<0.11)\end{array}$ & $\begin{array}{l}2.13 \mathrm{E} 5 \\
(0.60)\end{array}$ & $\begin{array}{l}7.82 \mathrm{E} 5 \\
(0.12)\end{array}$ & $\begin{array}{l}5.51 \mathrm{E} 5 \\
(0.12)\end{array}$ & $\begin{array}{l}4.98 \mathrm{E} 7 \\
(0.91)\end{array}$ & $\begin{array}{c}6.01 \mathrm{E} 3 \\
(0.03)\end{array}$ \\
\hline $\begin{array}{l}\text { Low-cesium particle } \\
\quad(323-\mathrm{SP} 02)\end{array}$ & $\begin{array}{l}1.73 \mathrm{E} 7 \\
(1.08)\end{array}$ & $\begin{array}{l}9.87 \mathrm{E} 3 \\
(0.14)\end{array}$ & $\begin{array}{l}2.47 \mathrm{E} 5 \\
(0.69)\end{array}$ & $\begin{array}{l}1.15 \mathrm{E} 6 \\
(0.17)\end{array}$ & $\begin{array}{l}7.51 \mathrm{E} 5 \\
(0.16)\end{array}$ & $\begin{array}{l}5.27 \mathrm{E} 7 \\
(0.97)\end{array}$ & $\begin{array}{l}1.32 \mathrm{E} 4 \\
(0.06)\end{array}$ \\
\hline $\begin{array}{l}\text { Low-cesium particle } \\
\quad(323-\mathrm{SP03})\end{array}$ & $\begin{array}{l}1.74 \mathrm{E} 7 \\
(1.08)\end{array}$ & $\begin{array}{l}<1.02 \mathrm{E} 4 \\
(<0.14)\end{array}$ & $\begin{array}{l}2.67 \mathrm{E} 5 \\
(0.75)\end{array}$ & $\begin{array}{l}2.51 \mathrm{E} 6 \\
(0.37)\end{array}$ & $\begin{array}{l}1.71 \mathrm{E} 6 \\
(0.36)\end{array}$ & $\begin{array}{l}6.38 \mathrm{E} 7 \\
(1.17)\end{array}$ & $\begin{array}{c}8.73 \mathrm{E} 2 \\
(0.00)\end{array}$ \\
\hline $\begin{array}{l}\text { Low-cesium particle } \\
\text { (323-SP04) }\end{array}$ & $\begin{array}{l}1.57 \mathrm{E} 7 \\
(0.98)\end{array}$ & $\begin{array}{l}<9.59 \mathrm{E} 3 \\
(<0.13)\end{array}$ & $\begin{array}{l}2.41 \mathrm{E} 5 \\
(0.67)\end{array}$ & $\begin{array}{l}2.58 \mathrm{E} 6 \\
(0.38)\end{array}$ & $\begin{array}{l}1.80 \mathrm{E} 6 \\
(0.38)\end{array}$ & $\begin{array}{l}5.67 \mathrm{E} 7 \\
(1.04)\end{array}$ & $\begin{array}{l}3.20 \mathrm{E} 3 \\
(0.02)\end{array}$ \\
\hline $\begin{array}{l}\text { Low-cesium particle } \\
\quad(323-\mathrm{SP} 05)\end{array}$ & $\begin{array}{l}1.65 \mathrm{E} 7 \\
(1.03)\end{array}$ & $\begin{array}{l}<9.70 \mathrm{E} 3 \\
(<0.13)\end{array}$ & $\begin{array}{l}2.52 \mathrm{E} 5 \\
(0.70)\end{array}$ & $\begin{array}{l}2.75 \mathrm{E} 6 \\
(0.41)\end{array}$ & $\begin{array}{l}1.89 \mathrm{E} 6 \\
(0.40)\end{array}$ & $\begin{array}{l}5.29 \mathrm{E} 7 \\
(0.97)\end{array}$ & $\begin{array}{c}8.53 \mathrm{E} 2 \\
(0.00)\end{array}$ \\
\hline $\begin{array}{l}\text { Low-cesium particle } \\
\quad(323-\text { SP06) }\end{array}$ & $\begin{array}{l}1.47 \mathrm{E} 7 \\
(0.91)\end{array}$ & $\begin{array}{l}<1.02 \mathrm{E} 4 \\
(<0.14)\end{array}$ & $\begin{array}{l}2.36 \mathrm{E} 5 \\
(0.66)\end{array}$ & $\begin{array}{l}3.22 \mathrm{E} 6 \\
(0.48)\end{array}$ & $\begin{array}{l}2.25 \mathrm{E} 6 \\
(0.47)\end{array}$ & $\begin{array}{l}5.46 \mathrm{E} 7 \\
(1.00)\end{array}$ & $\begin{array}{c}3.13 \mathrm{E} 3 \\
(0.02)\end{array}$ \\
\hline $\begin{array}{l}\text { Low-cesium particle } \\
\quad(323-\mathrm{SP} 07)\end{array}$ & $\begin{array}{l}1.59 \mathrm{E} 7 \\
(0.99)\end{array}$ & $\begin{array}{l}<1.12 \mathrm{E} 4 \\
(<0.15)\end{array}$ & $\begin{array}{l}2.41 \mathrm{E} 5 \\
(0.67)\end{array}$ & $\begin{array}{l}4.46 \mathrm{E} 6 \\
(0.66)\end{array}$ & $\begin{array}{l}2.96 \mathrm{E} 6 \\
(0.62)\end{array}$ & $\begin{array}{l}5.00 \mathrm{E} 7 \\
(0.92)\end{array}$ & $\begin{array}{c}1.70 \mathrm{E} 3 \\
(0.01)\end{array}$ \\
\hline $\begin{array}{l}\text { Low-cesium particle } \\
\quad(323-\mathrm{SP} 08)\end{array}$ & $\begin{array}{l}1.61 \mathrm{E} 7 \\
(1.00)\end{array}$ & $\begin{array}{l}<1.07 \mathrm{E} 4 \\
(<0.15)\end{array}$ & $\begin{array}{l}2.49 \mathrm{E} 5 \\
(0.70)\end{array}$ & $\begin{array}{l}3.67 \mathrm{E} 6 \\
(0.54)\end{array}$ & $\begin{array}{l}2.50 \mathrm{E} 6 \\
(0.53)\end{array}$ & $\begin{array}{l}5.96 \mathrm{E} 7 \\
(1.10)\end{array}$ & $\begin{array}{c}1.76 \mathrm{E} 3 \\
(0.01)\end{array}$ \\
\hline $\begin{array}{l}\text { Low-cesium particle } \\
\quad(323-\text { SP09) }\end{array}$ & $\begin{array}{l}1.51 \mathrm{E} 7 \\
(0.94)\end{array}$ & $\begin{array}{l}3.93 \mathrm{E} 4 \\
(0.54)\end{array}$ & $\begin{array}{l}2.27 \mathrm{E} 5 \\
(0.63)\end{array}$ & $\begin{array}{l}6.14 \mathrm{E} 6 \\
(0.91)\end{array}$ & $\begin{array}{l}4.41 \mathrm{E} 6 \\
(0.93)\end{array}$ & $\begin{array}{l}5.70 \mathrm{E} 7 \\
(1.05)\end{array}$ & $\begin{array}{c}1.55 \mathrm{E} 5 \\
(0.76)\end{array}$ \\
\hline $\begin{array}{l}\text { Low-cesium particle } \\
\quad(323-S P 10)\end{array}$ & $\begin{array}{l}1.51 \mathrm{E} 7 \\
(0.94)\end{array}$ & $\begin{array}{l}<1.20 \mathrm{E} 4 \\
(<0.17)\end{array}$ & $\begin{array}{l}2.37 \mathrm{E} 5 \\
(0.66)\end{array}$ & $\begin{array}{l}5.34 \mathrm{E} 6 \\
(0.79)\end{array}$ & $\begin{array}{l}3.69 \mathrm{E} 6 \\
(0.78)\end{array}$ & $\begin{array}{l}5.33 \mathrm{E} 7 \\
(0.98)\end{array}$ & $\begin{array}{c}1.31 \mathrm{E} 3 \\
(0.01)\end{array}$ \\
\hline $\begin{array}{l}\text { Low-cesium particle } \\
\quad(323-\mathrm{SP} 11)\end{array}$ & $\begin{array}{l}1.49 \mathrm{E} 7 \\
(0.93)\end{array}$ & $\begin{array}{c}7.28 \mathrm{E} 4 \\
(1.00)\end{array}$ & $\begin{array}{l}2.25 \mathrm{E} 5 \\
(0.63)\end{array}$ & $\begin{array}{l}6.14 \mathrm{E} 6 \\
(0.91)\end{array}$ & $\begin{array}{l}4.43 \mathrm{E} 6 \\
(0.93)\end{array}$ & $\begin{array}{l}5.60 \mathrm{E} 7 \\
(1.03)\end{array}$ & $\begin{array}{c}1.57 \mathrm{E} 5 \\
(0.77)\end{array}$ \\
\hline $\begin{array}{l}\text { Low-cesium particle } \\
\quad(323-\mathrm{SP} 12)\end{array}$ & $\begin{array}{l}1.67 \mathrm{E} 7 \\
(1.04)\end{array}$ & $\begin{array}{l}5.02 \mathrm{E} 4 \\
(0.69)\end{array}$ & $\begin{array}{l}2.52 \mathrm{E} 5 \\
(0.70)\end{array}$ & $\begin{array}{l}6.68 \mathrm{E} 6 \\
(0.99)\end{array}$ & $\begin{array}{l}4.62 \mathrm{E} 6 \\
(0.97)\end{array}$ & $\begin{array}{l}6.13 \mathrm{E} 7 \\
(1.13)\end{array}$ & $\begin{array}{c}1.66 \mathrm{E} 5 \\
(0.81)\end{array}$ \\
\hline
\end{tabular}

Values in parentheses are the measured/calculated ratios; highlighted cells indicate a measurable isotopic release. 
The randomly-selected particles from all three compacts exhibited relatively broad distributions in their ${ }^{110 \mathrm{~m}} \mathrm{Ag}$ inventories (Figure 8-Figure 10), reflecting the wide range in retention behavior that has been typical of AGR-1 fuel during irradiation [Hunn et al. 2012-1; Hunn et al. 2013-1; Hunn et al. 2014-1]. In these figures, the measured ${ }^{110 \mathrm{~m}} \mathrm{Ag}$ inventory has been divided by the calculated inventory, and adjusted for variation in fissile material and burnup using the ${ }^{137} \mathrm{Cs}$ activity (similar to the ${ }^{137} \mathrm{Cs}$ histograms earlier in this section).

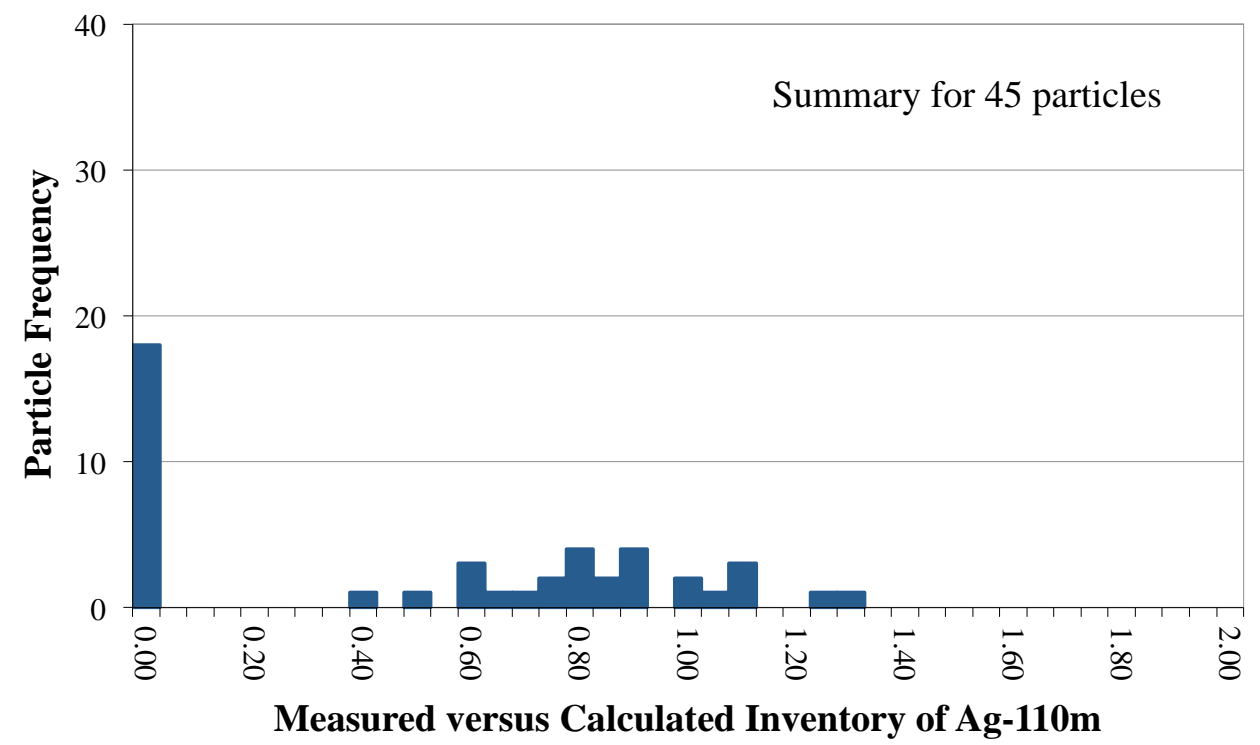

Figure 8. Ratio of ${ }^{110 \mathrm{~m}} \mathrm{Ag}$ retained in 45 particles randomly-selected from Compact 5-3-3. Note that the ${ }^{110 \mathrm{~m}} \mathrm{Ag}$ activity in these particles was very low at the time of analysis and uncertainty in peak analysis ranged from $\sim 12 \%$ for particles with more silver to $\sim 38 \%$ for particles with barely detectable silver. The 18 particles with undetectable inventory contained less than a minimum detectable $\mathrm{M} / \mathrm{C}$ of $0.20-0.24$.

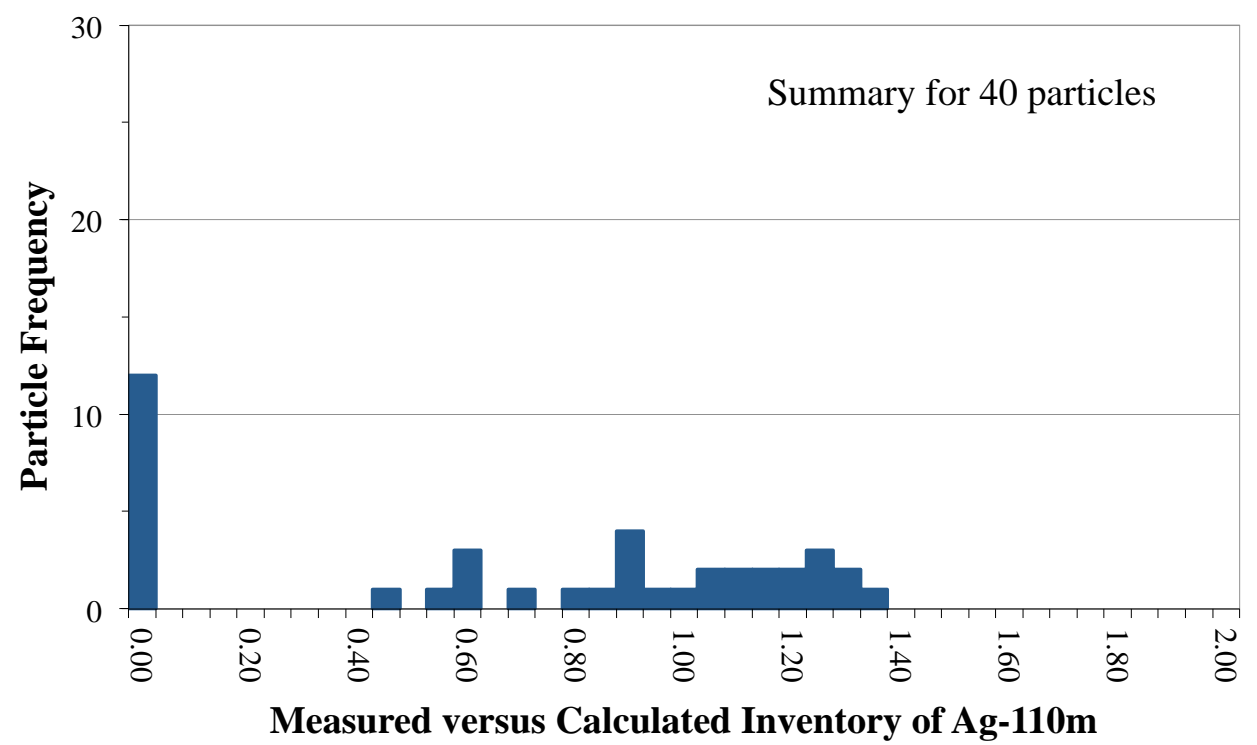

Figure 9. Ratio of ${ }^{110 \mathrm{~m}} \mathrm{Ag}$ retained in 40 particles randomly-selected from Compact 5-1-3. Uncertainty in ${ }^{110 \mathrm{~m}} \mathrm{Ag}$ peak analysis ranged from $\sim 12 \%$ for particles with more silver to $\sim 29 \%$ for particles with barely detectable silver. The 12 particles with undetectable inventory had an M/C $<0.19-0.22$. 


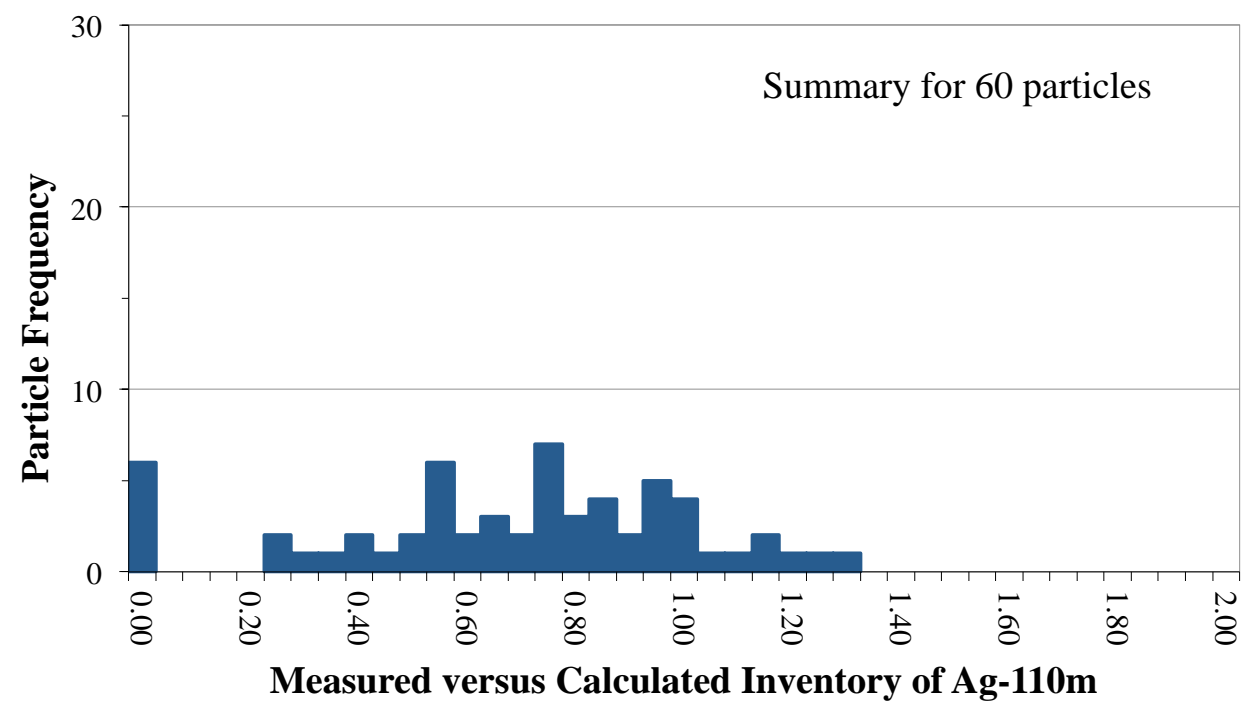

Figure 10. Ratio of ${ }^{110 \mathrm{~m}} \mathrm{Ag}$ retained in 60 particles randomly-selected from Compact 3-2-3. Uncertainty in peak analysis ranged from $\sim 12 \%$ for particles with more silver to $\sim 50 \%$ for particles with barely detectable silver. The 12 particles with undetectable inventory had an M/C $<0.23-0.25$.

\section{MICROSTRUCTURAL ANALYSIS OF INDIVIDUAL PARTICLES}

\section{Analysis of particles from randomly-selected IMGA samples}

Figure 11 shows $x-$ ray tomographs near midplane of two particles from Compact 5-3-3; these particles had significantly different silver retention, but very similar microstructure. Note that the OPyC layer is absent because these particles were subjected to IMGA examination and x-ray after completion of DLBL. Both these particles exhibited delamination between the buffer and IPyC. In Particle 533-RS36 there were still some tendrils between the buffer and IPyC where the buffer had torn away from the IPyC interface as it shrunk. Other than some fission product pileup at the IPyC/SiC interface, no other significant changes were noted.
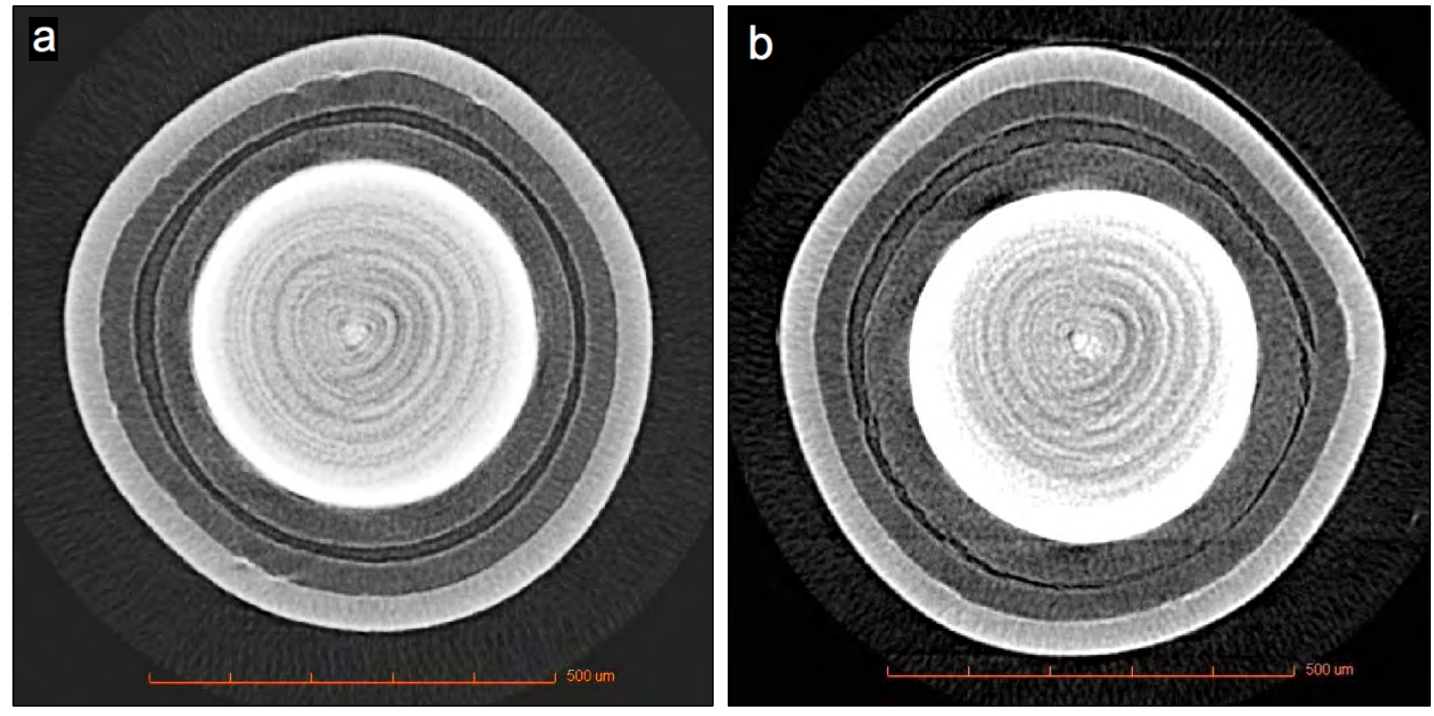

Figure 11. X-ray tomographs near midplane of (a) Particle 533-RS16 with measurably reduced ${ }^{110 \mathrm{~m}} \mathrm{Ag}$ inventory $(\mathrm{M} / \mathrm{C}<0.22)$ and (b) Particle 533-RS36 with average ${ }^{110 \mathrm{~m}} \mathrm{Ag}$ inventory $(\mathrm{M} / \mathrm{C}=0.88)$. Bright features at the IPyC/SiC interface are fission products. Rings in kernel are tomography artifacts. 
Figure 12 shows optical micrographs of four additional randomly-selected particles from Compact 5-3-3 after grinding and polishing to midplane; these particles exhibited buffer/IPyC delamination and otherwise intact TRISO coatings similar to the internal microstructures in the Compact 5-3-3 particles examined by x-ray. Kernel structure in three of the particles was very similar, with large internal pores surrounded by what looked like a remnant of the uranium oxide rind typically found in the majority of AGR-1 mixed uranium carbide/uranium oxide (UCO) fuel kernels. The fourth particle (Figure 12c) had a different irradiated kernel microstructure that probably evolved from a pre-irradiated kernel

microstructure that had very little oxide rind. The AGR-1 Compact 6-1-1 PIE report [Hunn et al. 2012-1] includes further discussion of irradiated kernel microstructure with comparison to different types of asfabricated UCO microstructures [Kercher and Hunn 2005]. In this limited sampling of particles from Compact 5-3-3, there does not seem to be any correlation between ${ }^{110 \mathrm{~m}} \mathrm{Ag}$ inventory and the radiationinduced evolution in the kernels or coatings.
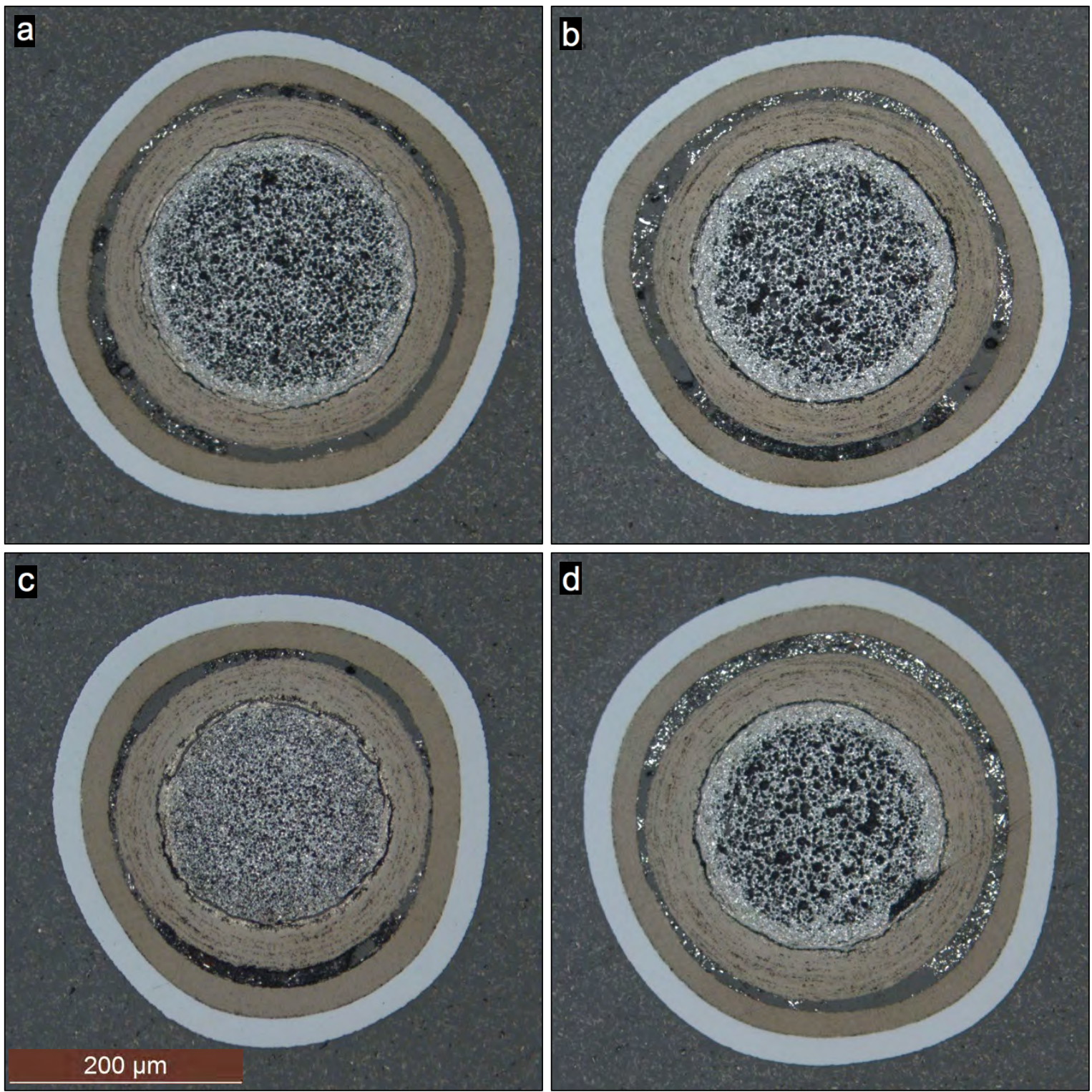

Figure 12. Optical micrographs near midplane of particles from Compact 5-3-3: a) Particle 533-RS23 with high ${ }^{110 \mathrm{~m}} \mathrm{Ag}$ release $(\mathrm{M} / \mathrm{C}<0.21)$, b) Particle $533-\mathrm{RS} 20$ with moderate ${ }^{110 \mathrm{~m}} \mathrm{Ag}$ release $(\mathrm{M} / \mathrm{C}=0.58)$, c) Particle 533-RS24 with marginal ${ }^{110 \mathrm{~m}} \mathrm{Ag}$ release $(\mathrm{M} / \mathrm{C}=0.81)$, and d) Particle 533-RS04 with very low ${ }^{110 \mathrm{~m}} \mathrm{Ag}$ release $(\mathrm{M} / \mathrm{C}=1.10)$. 
SEM imaging was performed on the sectioned Compact 5-3-3 particles in Figure 12. Observations were similar to those reported previously [Hunn et al. 2014-3], where a general trend for fission product distribution in the $\mathrm{SiC}$ as a function of silver retention was discussed. The $\mathrm{BEC}$ images in Figure 13 are decorated with bright spots in the $\mathrm{SiC}$ indicating increased backscattering from near-surface clusters of elements with higher atomic number $(Z)$ than the surrounding material. These clusters could be seen throughout the $\mathrm{SiC}$ in particles that released silver (Figure 13a, b and c), but tended to be localized to the $\mathrm{IPyC} / \mathrm{SiC}$ interface in the particle with a retained ${ }^{110 \mathrm{~m}} \mathrm{Ag}$ inventory above the calculated average (Figure 13d) that presumably released very little or no silver. High-Z clusters analyzed by EDS are indicated in Figure 13 by diamonds $(\mathrm{Pd})$ and squares $(\mathrm{U})$, with dashed lines indicating lower relative peak intensity. Palladium was found in every analyzed cluster within the SiC layer. Uranium was often observed collocated with the palladium in the clusters less than $10 \mu \mathrm{m}$ from the IPyC/SiC interface and sometimes in the larger clusters further out into the $\mathrm{SiC}$. Other elements (not shown) were sometimes observed in the clusters located in the interlaced region between the IPyC and SiC, or in spots in the IPyC layer away from the $\mathrm{SiC}$ (clusters isolated in the IPyC often contained uranium but rarely contained palladium).
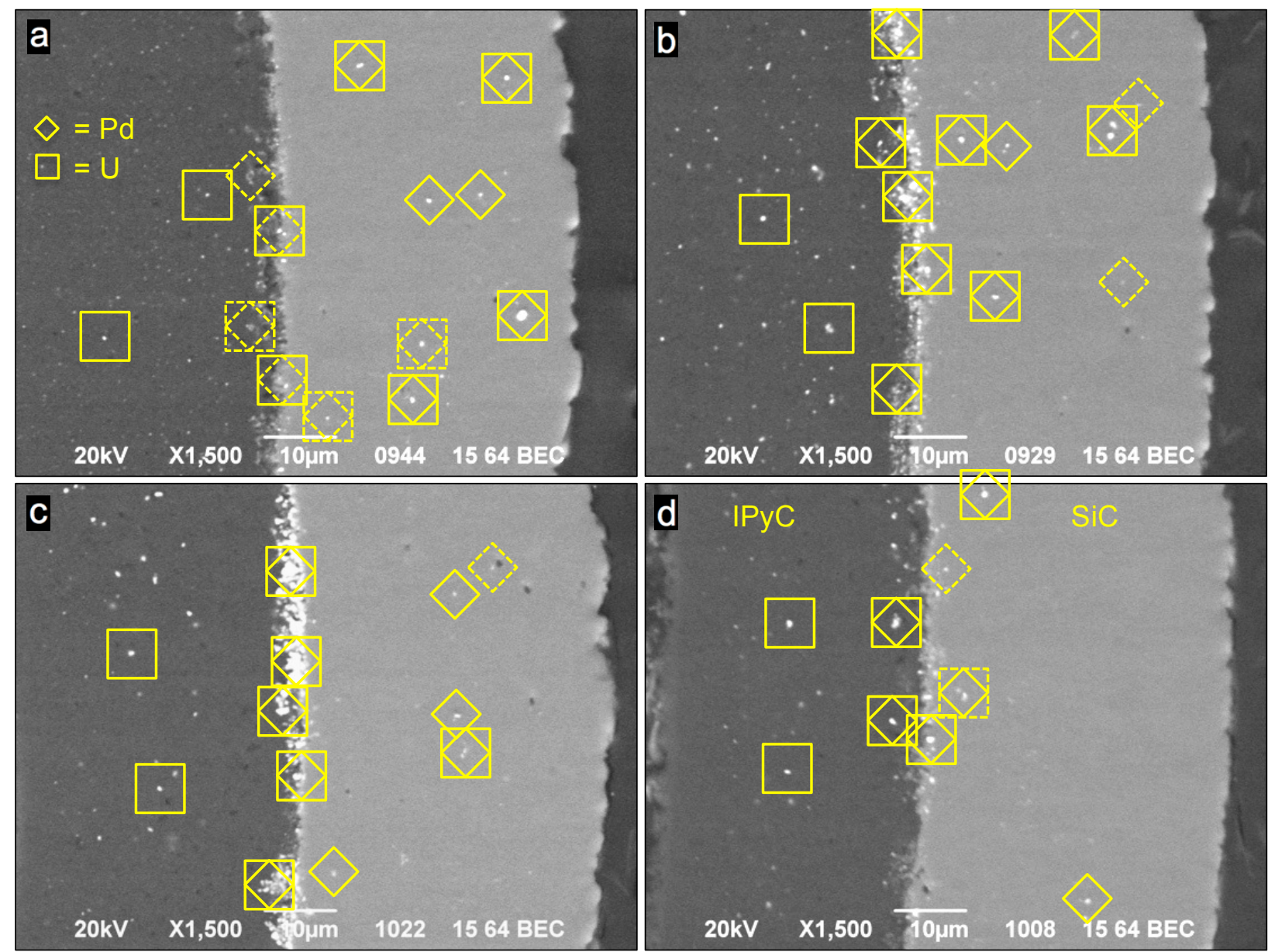

Figure 13. Backscattered-electron composition micrographs showing representative IPyC and $\mathrm{SiC}$ of Compact 5-3-3 particles shown in Figure 12: a) Particle 533-RS23 with high ${ }^{110 \mathrm{~m}} \mathrm{Ag}$ release $(\mathrm{M} / \mathrm{C}<0.21)$, b) Particle 533-RS20 with moderate ${ }^{110 \mathrm{~m}} \mathrm{Ag}$ release $(\mathrm{M} / \mathrm{C}=0.58)$, c) Particle 533-RS24 with marginal ${ }^{110 \mathrm{~m}} \mathrm{Ag}$ release $(\mathrm{M} / \mathrm{C}=0.81)$, and $\left.\mathrm{d}\right)$ Particle 533-RS04 with very low ${ }^{110 \mathrm{~m}} \mathrm{Ag}$ release $(\mathrm{M} / \mathrm{C}=1.10)$. Dashed diamonds or squares indicate relatively less Pd or U were detected.

Two particles were selected from Compact 5-1-3 for x-ray imaging, one with low but measurable ${ }^{110 \mathrm{~m}} \mathrm{Ag}$ inventory $(\mathrm{M} / \mathrm{C}=0.55$ average $)$ and one with slightly more than the calculated average ${ }^{110 \mathrm{~m}} \mathrm{Ag}$ inventory $(\mathrm{M} / \mathrm{C}=1.09)$. These particles exhibited delamination at the buffer/IPyC interface (Figure 14) similar to that observed in the Compact 533 randomly-selected particles. Particle 513-RS09 (Figure 14b) also 
experienced buffer fracture and had some unusually large fission product clusters located in one region where the buffer was the most fragmented. Figure 15 is a $3 \mathrm{D}$ visualization that shows these fission product clusters. Figure 15 also shows smaller fission product clusters distributed all around the IPyC/SiC interface; the prevalence of these clusters compared to Compact 5-3-3 may be due to the higher temperature furnace testing.
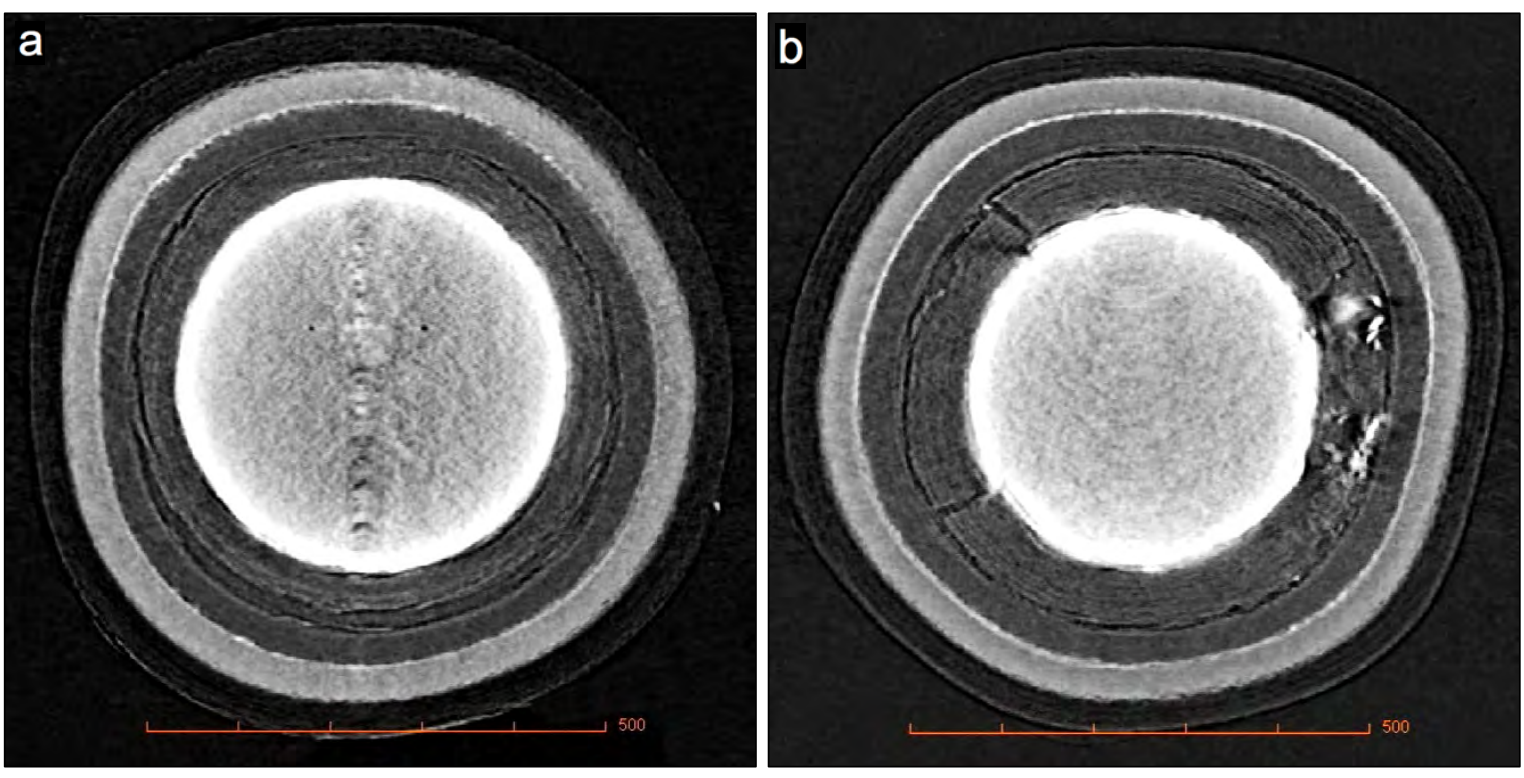

Figure 14. X-ray tomographs near midplane of (a) Particle 513-RS13 with measurably reduced ${ }^{110 \mathrm{~m}} \mathrm{Ag}$ inventory $(\mathrm{M} / \mathrm{C}=0.55)$ and (b) Particle 513-RS09 with above average ${ }^{110 \mathrm{~m}} \mathrm{Ag}$ inventory $(\mathrm{M} / \mathrm{C}=1.09)$. Bright features at the IPyC/SiC interface and in the buffer fractures are fission products.

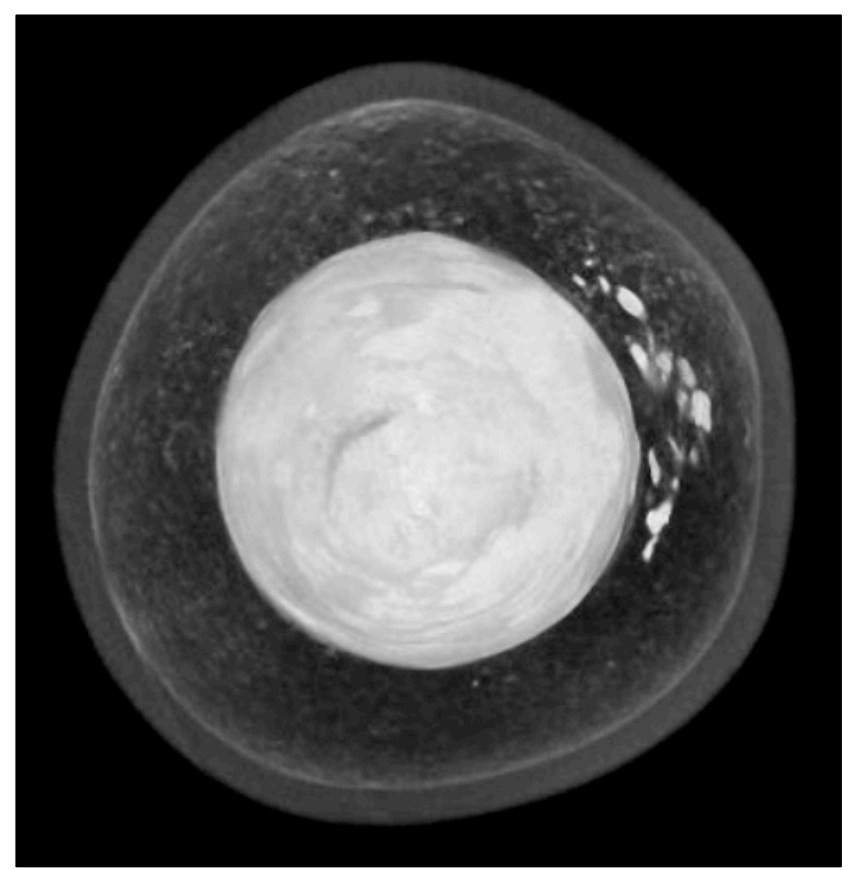

Figure 15. Three-dimensional x-ray visualization of Particle 513-RS09 showing large clusters of fission products in one region of the buffer, as well as smaller clusters distributed uniformly around the IPyC/SiC interface. 
Figure 16 shows x-ray tomographs near midplane of two particles from Compact 3-2-3 with high and low silver release. Both particles had fractured buffer with significant kernel protrusion into the gaps between the buffer fragments. Compact 3-2-3 exhibited more kernel protrusion than any other AGR-1 compact examined by x-ray tomography, presumably due to its relatively high burnup. In fact, every particle that was imaged by x-ray tomography had fractured buffer and protruding kernels (all twelve speciallyselected particles listed in Table 8 and three randomly-selected particles). Although neither of the particles in Figure 16 released cesium, both showed localized SiC degradation typical of particles with failed SiC. Figure 16a shows fission product concentration and $\mathrm{SiC}$ attack in the upper left quadrant that is associated with a very minor IPyC crack; Figure 16b shows a similar feature in the upper right quadrant without an obvious associated IPyC crack. Figure $16 \mathrm{~b}$ also shows heavy buildup of fission products in the lower left quadrant where the kernel has protruded all the way to the IPyC layer.
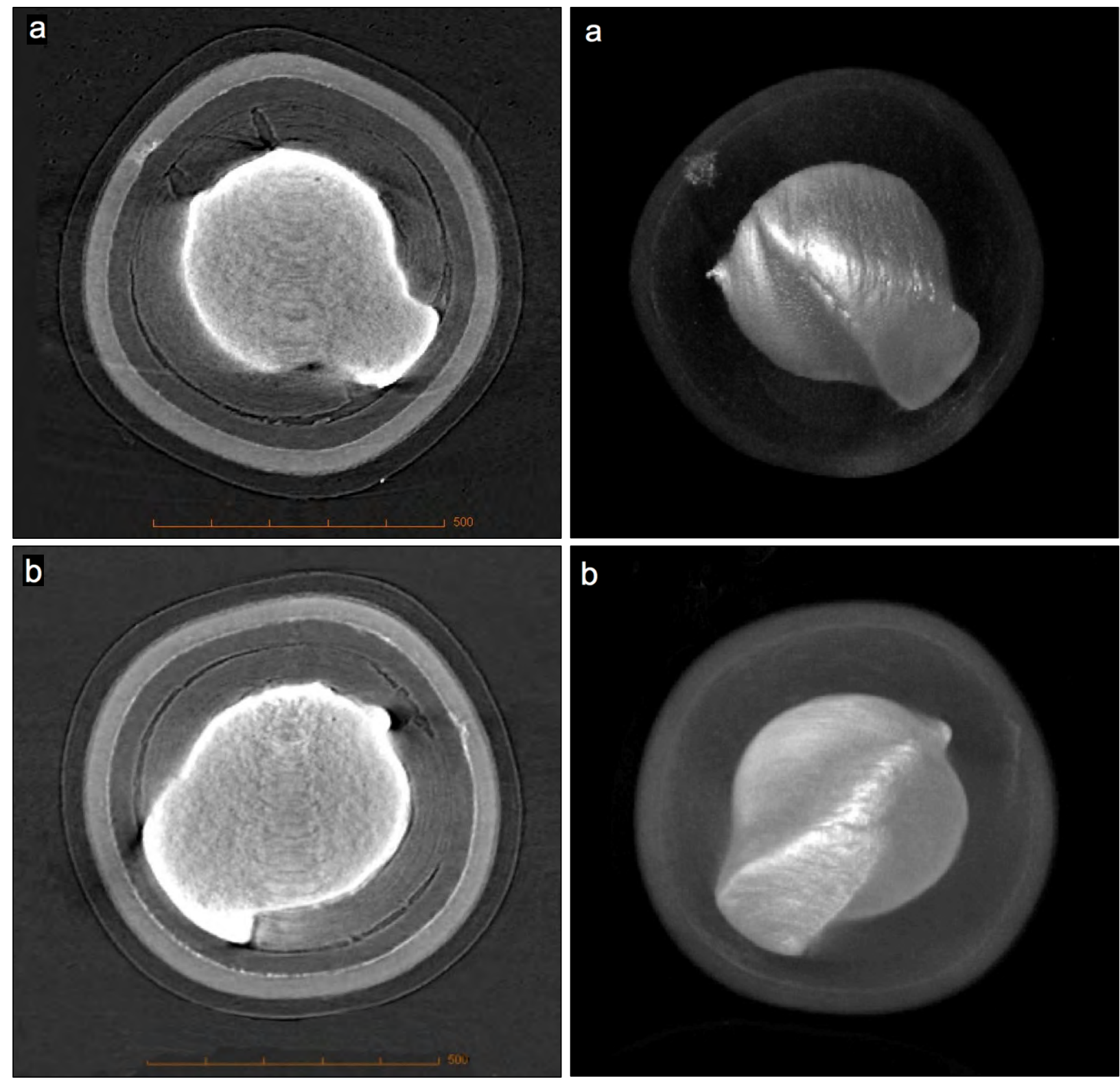

Figure 16. X-ray tomographs near midplane of particles from Compact 3-2-3 and 3D visualizations highlighting the kernel shape for a) Particle 323-RS34 with very low ${ }^{110 \mathrm{~m}} \mathrm{Ag}$ inventory $(\mathrm{M} / \mathrm{C}<0.24)$, and b) Particle $323-\mathrm{RS} 17$ with negligible ${ }^{110 \mathrm{~m}} \mathrm{Ag}$ release $(\mathrm{M} / \mathrm{C}=1.29)$. 
A third particle from the Compact 3-2-3 60-particle subsample randomly selected for 5-hour IMGA counting was chosen for x-ray analysis because it exhibited not only very-high silver release, but also very-high europium release, which is unusual for a particle that has not also released cesium due to a failed SiC layer. Similar to the particles discussed above, Figure 17 shows that this particle also has the typical fractured buffer, cracked IPyC, and fission product-related SiC degradation usually observed in particles with significant cesium release due to failed SiC [Hunn et al. 2014-2]. The SiC degradation in this particle (right side of upper image) appears to penetrate the layer, but this would not be consistent with the fact that the cesium retention in this particle was within the normal variation observed in an undamaged particle. Because europium can pass through intact $\mathrm{SiC}$, it would be reasonable to presume that a very thin intact $\mathrm{SiC}$ region at the tip of the degraded region might have retained cesium, but readily released europium.
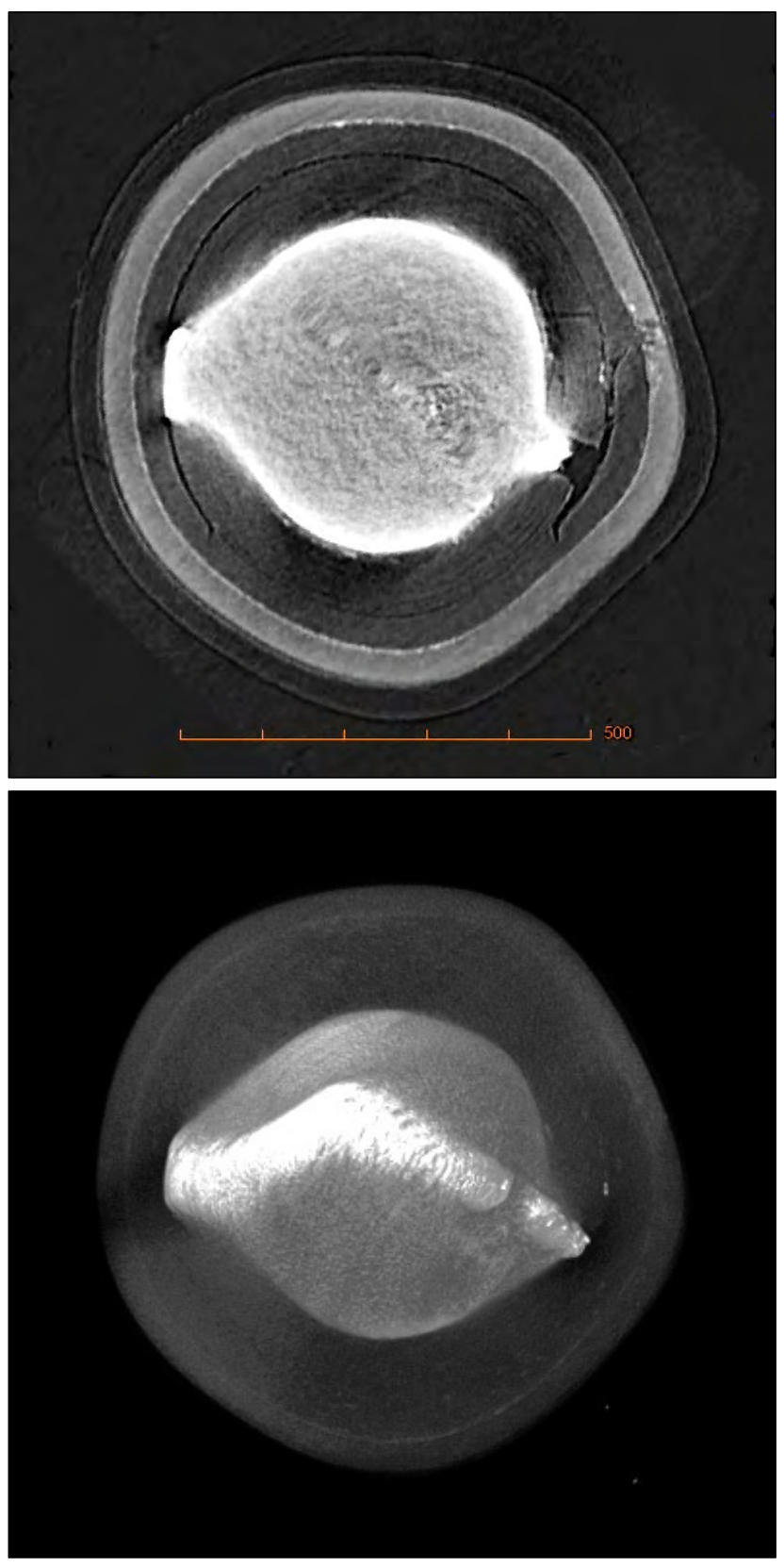

Figure 17. X-ray tomograph near midplane and 3D visualization highlighting the kernel shape of Particle 323 -RS51 with very-low ${ }^{110 \mathrm{~m}} \mathrm{Ag}$ inventory $(\mathrm{M} / \mathrm{C}<0.23)$ and also very-low ${ }^{154} \mathrm{Eu}$ inventory $(\mathrm{M} / \mathrm{C}=0.01)$. 
Six particles from Compact 5-1-3 and four from Compact 3-2-3 with silver release varying from very high to very low where mounted, polished, and imaged with an optical microscope. Four of the particles from Compact 5-1-3 and three from Compact 3-2-3 exhibited similar internal structure to those examined from Compact 5-3-3 and shown in Figure 12 (delamination between buffer and IPyC with no significant coating damage); study of sections through 830 TRISO particles has shown this internal structure to be the most common for AGR-1 irradiation test fuel and it has been labeled as Type Ai [Ploger, Demkowicz, and Hunn 2012]. The fourth Compact 3-2-3 particle had a Type Bi structure (four intact layers with no delamination between the buffer and IPyC). The other two Compact 5-1-3 particles had cracked IPyC, and Figure 18 shows that these IPyC cracks resulted in mild $\mathrm{SiC}$ degradation at the IPyC/SiC interface.
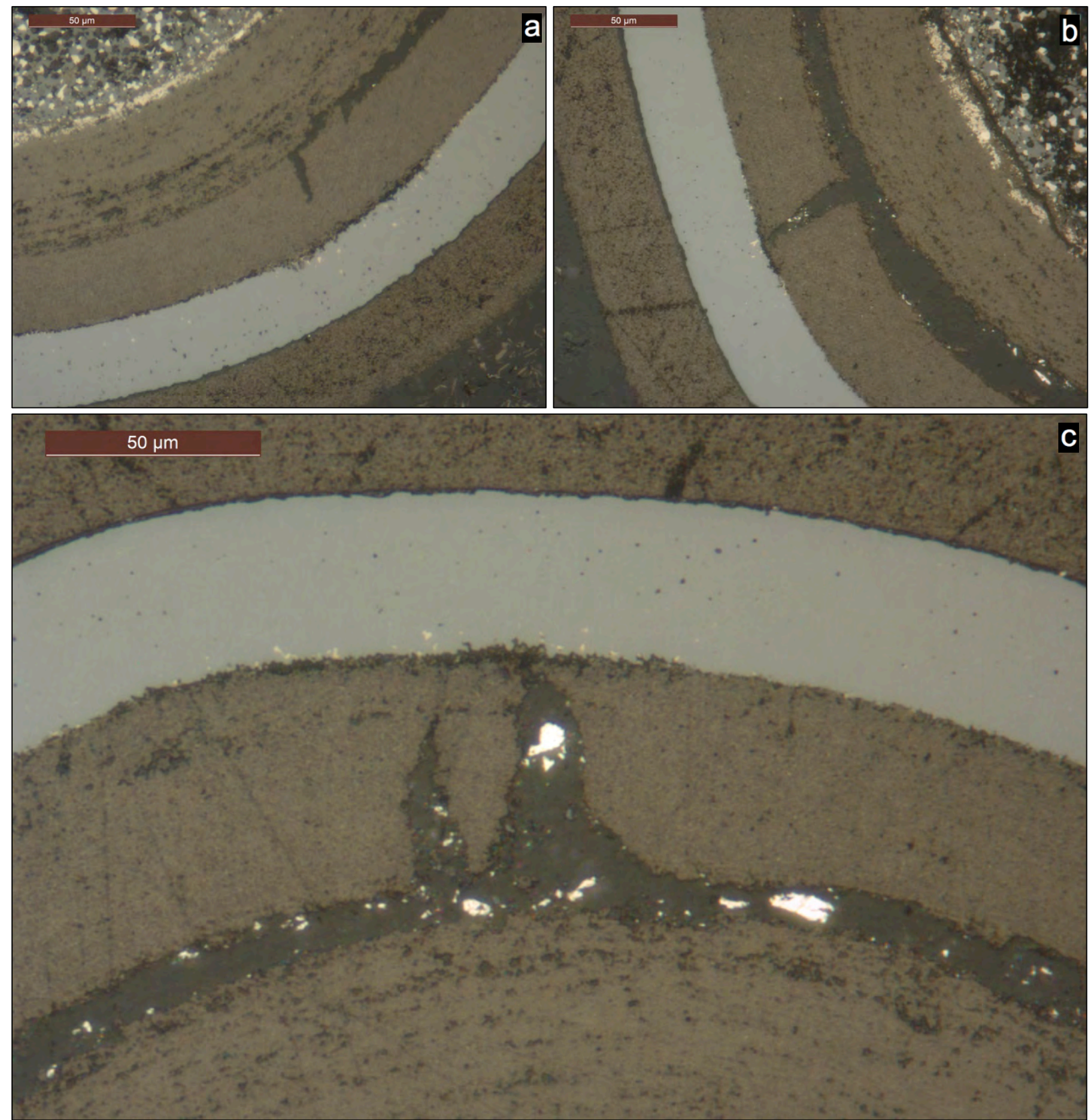

Figure 18. Optical micrographs near midplane of particles from Compact 5-1-3: a) Particle 513-RS06 with high ${ }^{110 \mathrm{~m}} \mathrm{Ag}$ release $(\mathrm{M} / \mathrm{C}<0.22)$, b) and c) Particle 513-RS26 with moderate ${ }^{110 \mathrm{~m}} \mathrm{Ag}$ release $(\mathrm{M} / \mathrm{C}=0.58)$. 
Figure 19 shows SEI/BEC image pairs of the degraded SiC regions in Particles 513-RS06 and RS26. The SEI images provide good topographical data, while the BEC images show more fission products in the $\mathrm{SiC}$ due to the higher analysis depth and sensitivity to higher-Z elements. SiC appears to have been removed from the IPyC/SiC interface close to the IPyC cracks. Some fingers of corrosion extending away from this interface appeared to be full of carbon (presumably a result of formation and out-diffusion of silicide). The large fission product clusters (bright spots) in the $\mathrm{SiC}$ surrounding the degraded area contain predominantly uranium; palladium is conspicuously absent. The dark spots in the $\mathrm{SiC}$ are carbon-rich material and/or surface pits that presumably mark locations where palladium once resided.
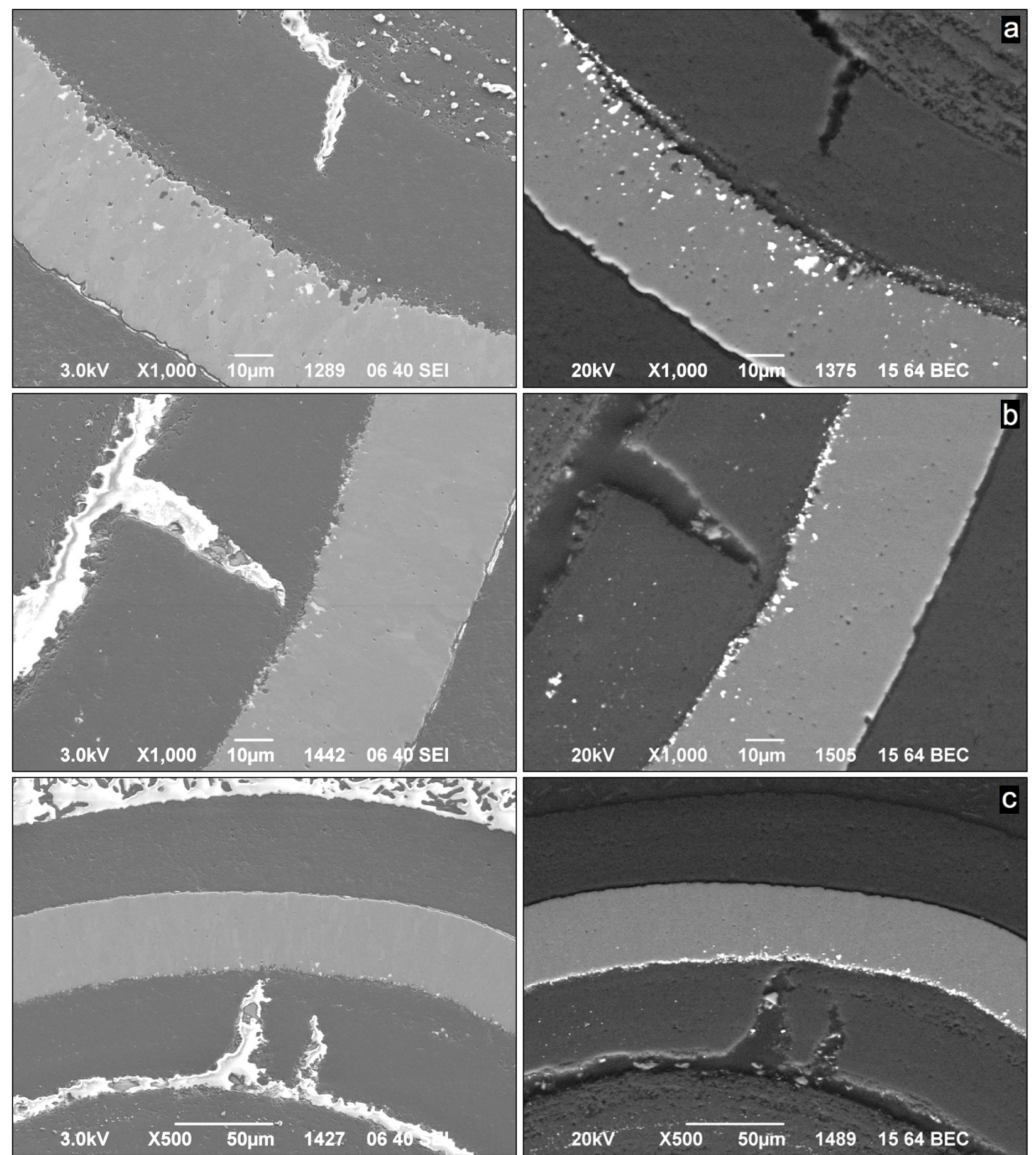

Figure 19. SEI/BEC-paired images of Compact 5-1-3 particles shown in Figure 18. 
The absence of palladium and presumably-related preponderance of carbon-rich spots was a common feature of all the particles examined after $1800^{\circ} \mathrm{C}$ safety testing, including Compact 4-4-1 (previously reported [Hunn et al. 2013-3]). This observation has also been observed in particles from compacts tested at $1700^{\circ} \mathrm{C}$ [Hunn et al. 2014-3]. Figure 20 shows a Compact 3-2-3 particle that released most of its silver; this particle has much less palladium in the $\mathrm{SiC}$ compared to as-irradiated or $1600^{\circ} \mathrm{C}$ safety-tested particles (e.g., Figure 13). After the 300 -hour soak at $1800^{\circ} \mathrm{C}$, only uranium appears to remain in the $\mathrm{SiC}$ where collocated palladium and uranium are usually observed, and where palladium would normally be observed by itself (further out in the $\mathrm{SiC}$ ), only carbon-rich features and surface pits remain. Presumably, palladium silicide was initially in these features at the end of irradiation, but the palladium and silicon have migrated away during safety testing, leaving carbon-rich material and voids behind.
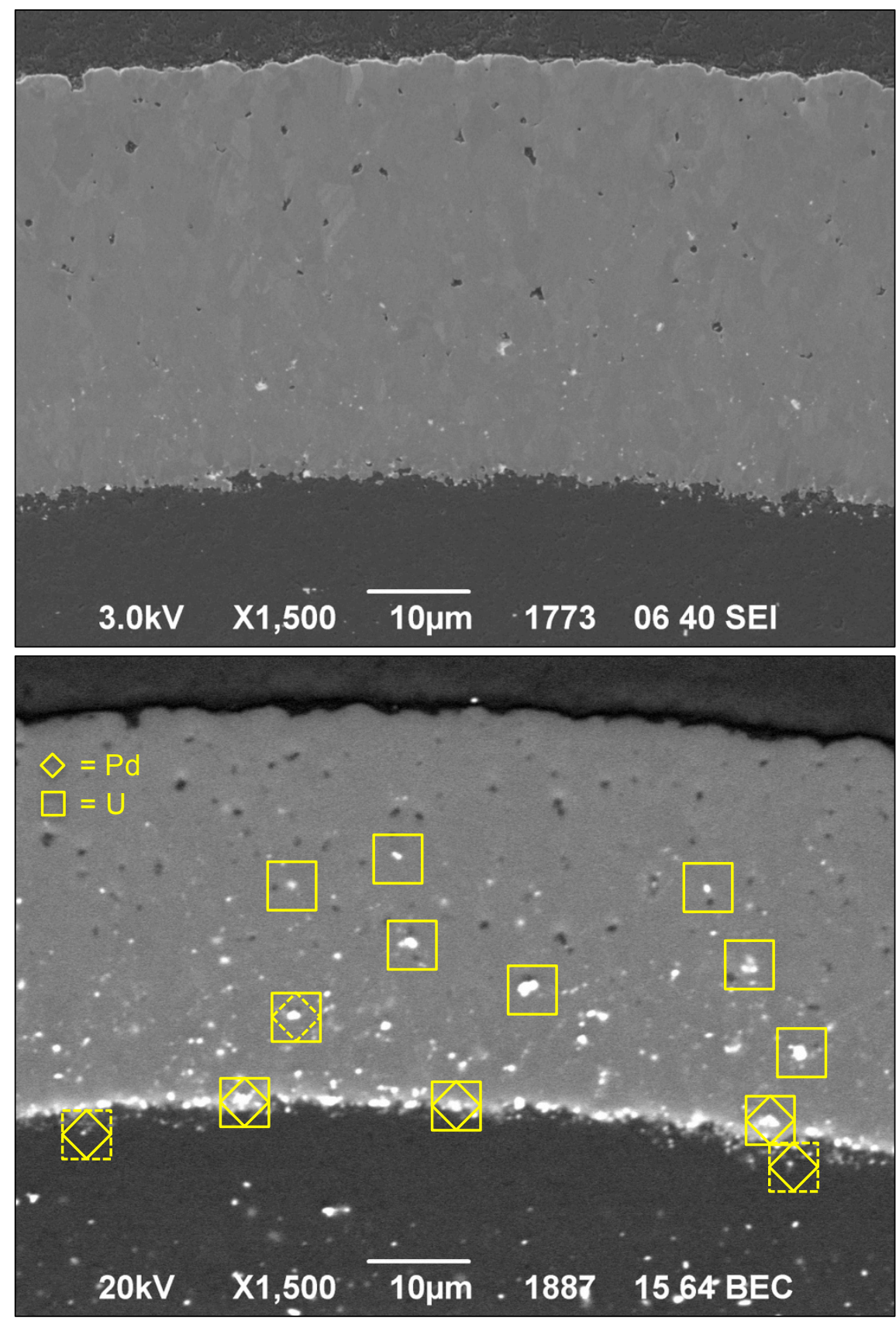

Figure 20. SEI/BEC-paired images of SiC region in Compact 3-2-3 Particle 323-RS50 with high ${ }^{110 \mathrm{~m}} \mathrm{Ag}$ release $(\mathrm{M} / \mathrm{C}<0.25)$. Dashed diamonds or squares indicate relatively less Pd or $\mathrm{U}$ were detected. 


\section{Analysis of particles from Compacts 5-1-3 and 3-2-3 that were specially-selected by IMGA due to reduced cesium inventory}

After IMGA analysis was completed on the specially-selected particles that had low ${ }^{137} \mathrm{Cs} /{ }^{144} \mathrm{Ce}$ ratios and may have released cesium during safety testing at $1800^{\circ} \mathrm{C}$ (Table 7 and Table 8 ), they were mounted in epoxy using individual plastic holders for x-ray tomography. As mentioned in the discussion of Table 7, Particle 513-SP02 had an undersized kernel $(\sim 325-\mu \mathrm{m}$ diameter even after any radiation-induced swelling) and was not otherwise unusual (Figure 21). Particles with undersized kernels were sometimes not removed during AGR-1 coated particle upgrading with a roller micrometer because of the tendency for the small kernels to receive a thicker buffer coating, producing final TRISO particle diameters similar to particles containing full-sized kernels [Hunn, Montgomery, and Pappano 2006-1, Appendix C].

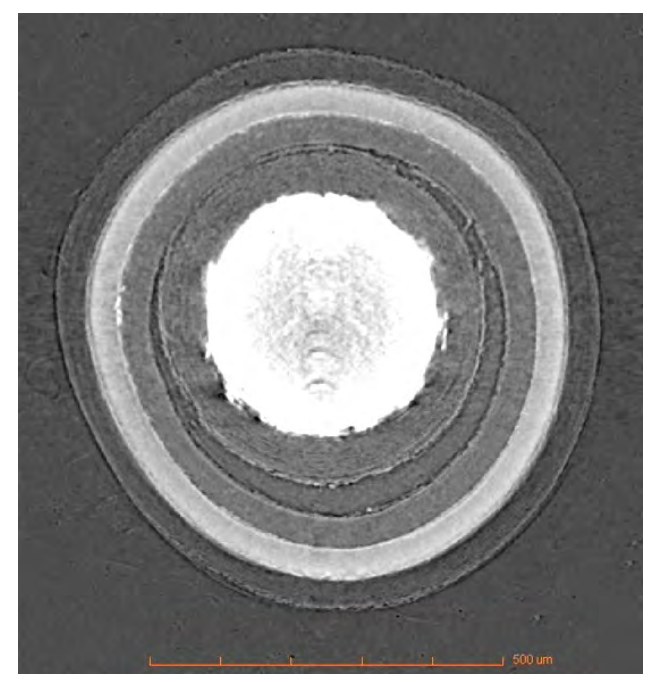

Figure 21. X-ray tomograph of Particle 513-SP02 showing undersized kernel.

As mentioned in the discussion of Table 8, Particles 323-SP09, SP11, and SP12 all had slightly low ${ }^{137} \mathrm{Cs} /{ }^{144} \mathrm{Ce}$ ratios (still part of the main distribution in Figure 7, but in the lower tail). X-ray tomography revealed that Particles 323-SP11 and SP12 had the fractured buffer and protruding kernels that were apparently typical for Compact 3-2-3 (Figure 22), but no significant damage to the three outer coating layers (other than some separation between the $\mathrm{SiC}$ and $\mathrm{OPyC}$ that is also typical for particles safety tested at $1800^{\circ} \mathrm{C}$ [Hunn et al. 2013-3, page 27]). Particle 323-SP09 is shown in Figure 23. It had cracked $\mathrm{IPyC}$ and $\mathrm{x}$-ray tomography showed the onset of $\mathrm{SiC}$ degradation in several locations. The $\mathrm{SiC}$ degradation did not appear to penetrate the layer and it is unclear if any cesium release was related to these features, given that the cesium inventory was within a range that could be accredited to statistical variation and measurement uncertainty.
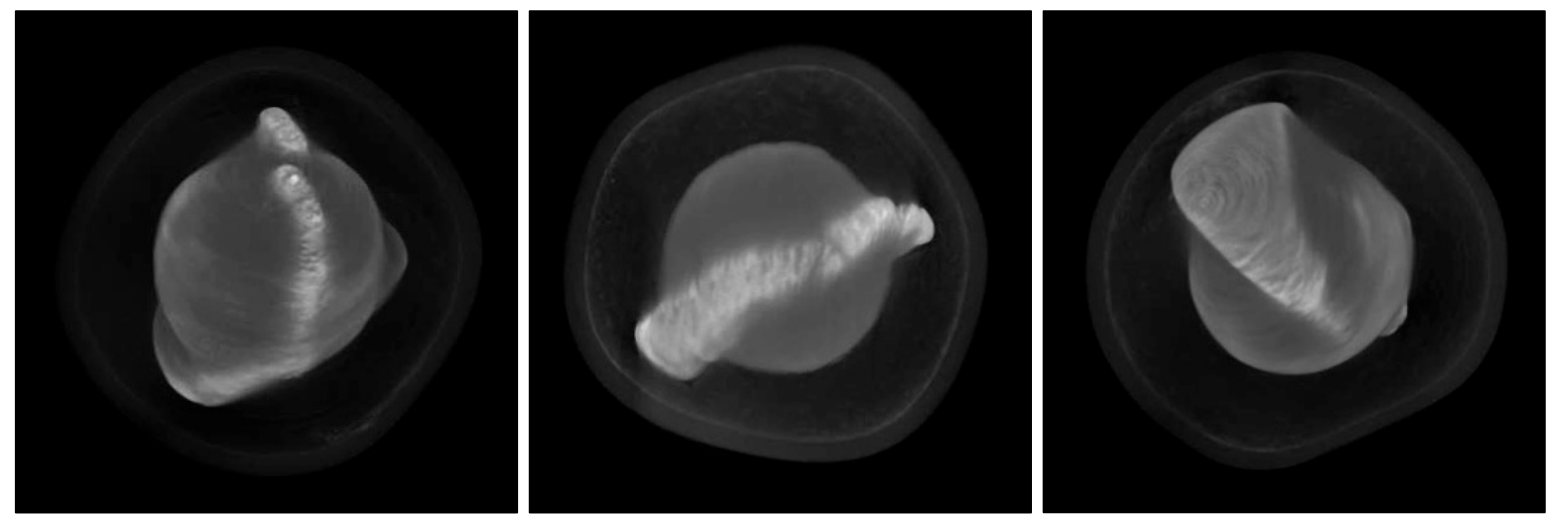

Figure 22. Kernels from Particles 323-SP09, SP11, and SP12. 


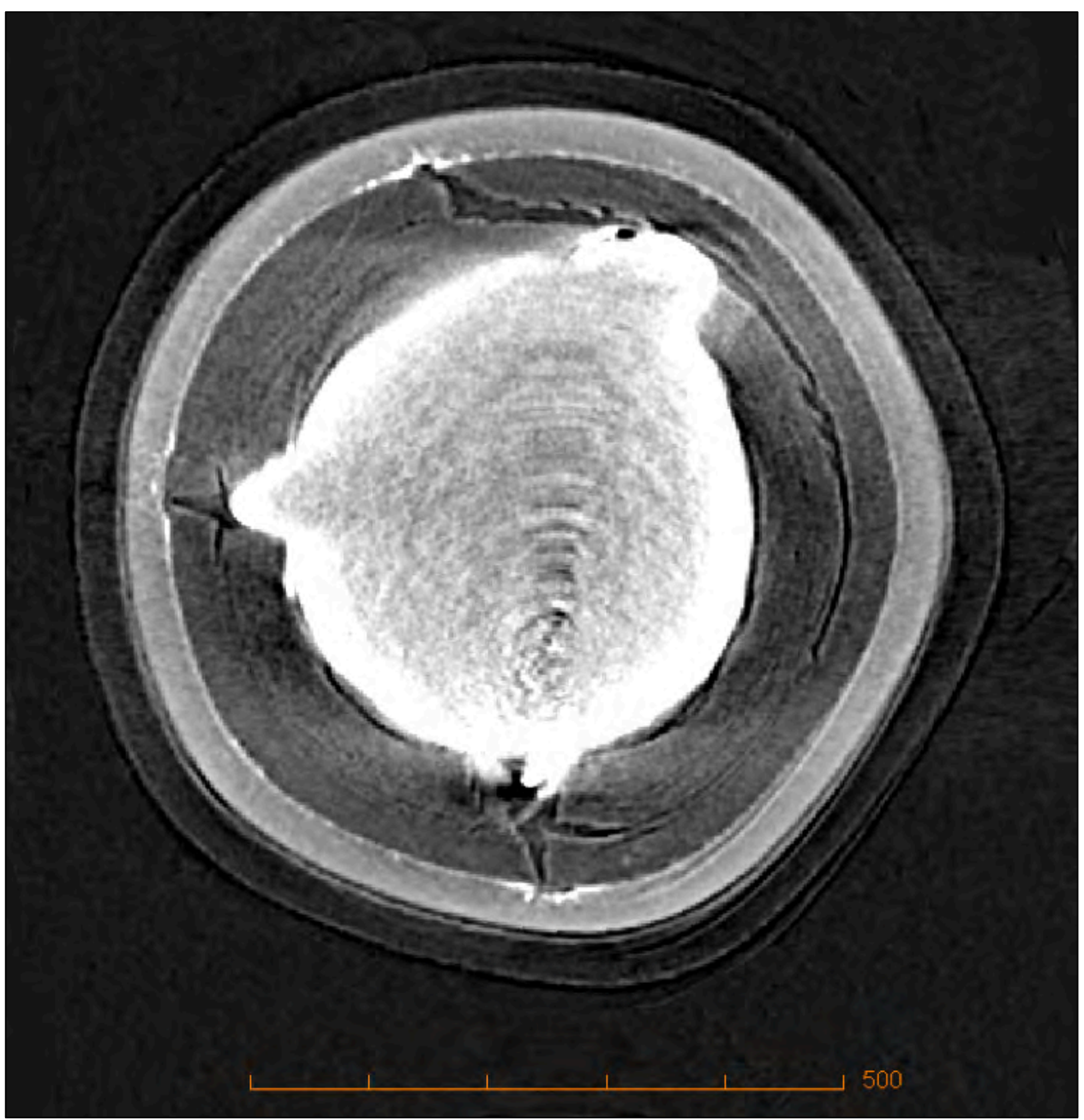

Figure 23. X-ray tomograph of Particle 323-SP09 showing IPyC cracks with associated fission product pile-up (bright regions) and SiC degradation in the vicinity of the IPyC crack. This particle had slightly low cesium, silver, and europium (Table 8).

Five of the Compact 5-1-3 specially-selected particles listed in Table 7 (Particles 513-SP03-SP07) had reduced cesium inventories that are presumed to be the source of the cesium release detected during safety testing (Figure 5). These particles exhibited the same general internal defect structure, which followed the trend observed in other particles with $\mathrm{SiC}$ failure in either an as-irradiated condition [Hunn et al. 2014-1] or after $1700-1800^{\circ} \mathrm{C}$ safety testing [Hunn et al. 2014-2]. Buffer fracture and/or delamination of the buffer from the IPyC layer appeared to have caused the IPyC layer to crack. Many of the IPyC cracks extended to the inside surface of the $\mathrm{SiC}$, exposing the surface to additional interaction with fission products (predominantly palladium and uranium). In the Compact 5-1-3 particles with failed $\mathrm{SiC}$, IPyC cracks often continued to propagate along the IPyC/SiC interface, sometimes crossing over into the $\mathrm{SiC}$ and pulling away a thin layer of $\mathrm{SiC}$ from the inside surface of the layer. However, even where cracks propagated tangentially into the $\mathrm{SiC}$, low density pathways penetrating the $\mathrm{SiC}$ (observed in the $3 \mathrm{D} x$-ray images) appeared to be related to fission product degradation rather than $\mathrm{SiC}$ cracks propagating in the radial direction. Figure 24-Figure 28 show Particles 513-SP03-SP07 in two orthogonal midplanes with the failed $\mathrm{SiC}$ region located at the bottom of each image. These image pairs provide a "three-dimensional" view of the kernel/buffer/IPyC structure that led to the SiC failure. Particle 513-SP07, which had the lowest cesium release of the five Compact 5-1-3 particles identified to have failed $\mathrm{SiC}$ (Table 7), also had the least $\mathrm{SiC}$ degradation and a through-layer pathway in the degraded region was less-evident in the $\mathrm{X}$-ray images. 

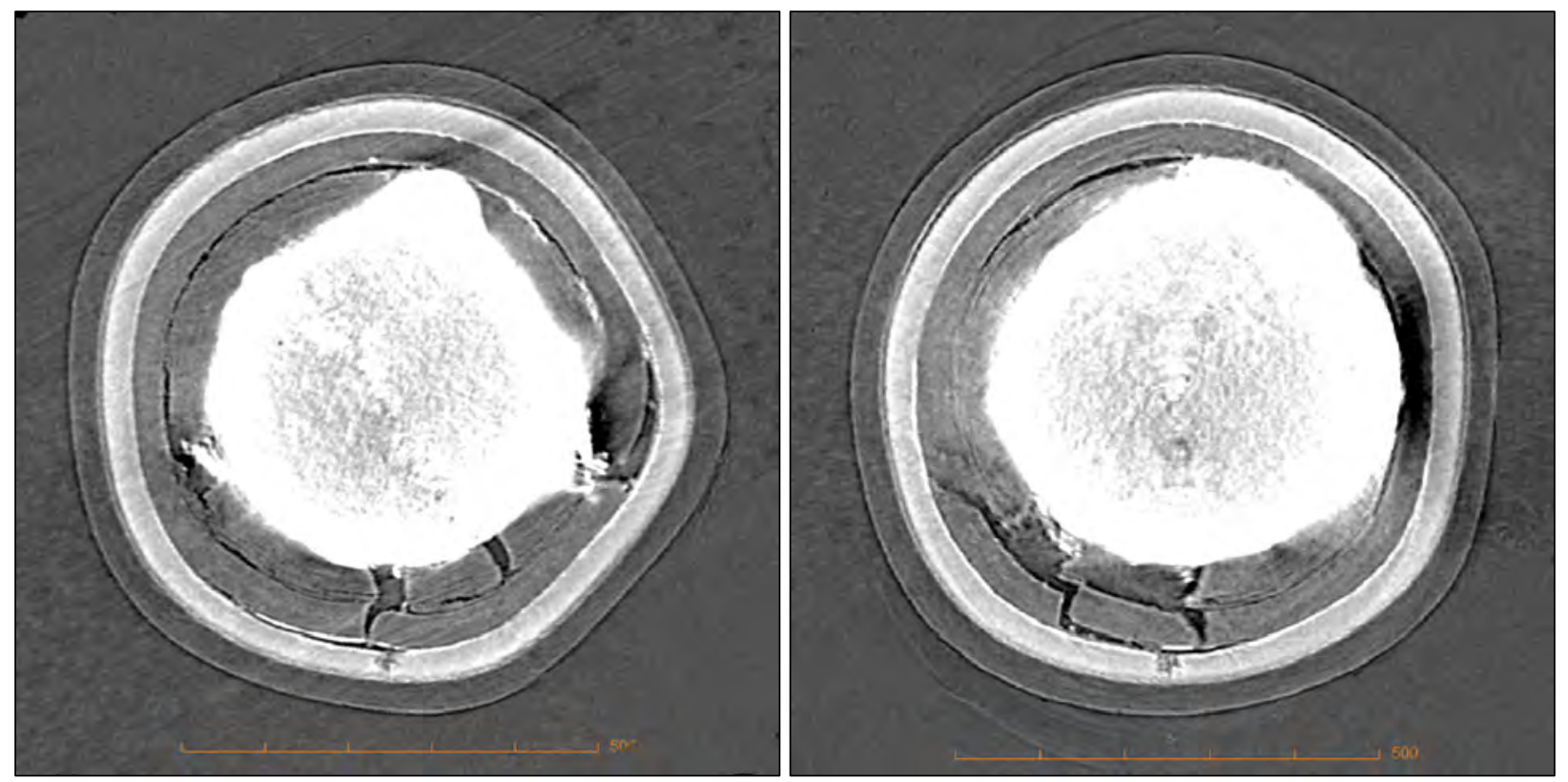

Figure 24. Pair of orthogonal x-ray tomographs showing region of SiC failure in Particle 513-SP03: buffer fracture $\rightarrow$ IPyC crack $\rightarrow$ IPyC/SiC delamination and tangential $\mathrm{SiC}$ crack $\rightarrow$ fission product concentration and $\mathrm{SiC}$ degradation at the bottom of image.
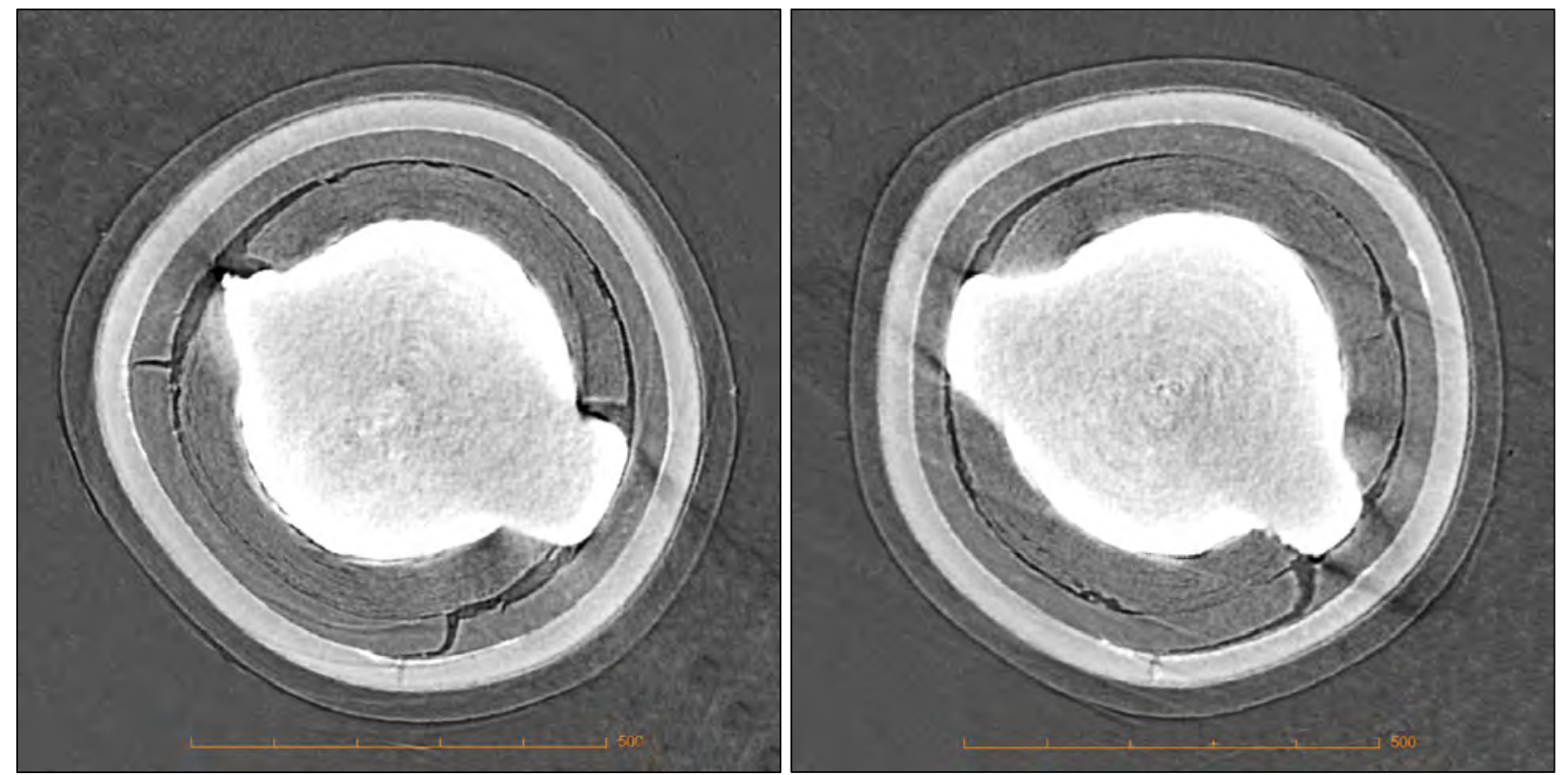

Figure 25. Pair of orthogonal x-ray tomographs showing region of SiC failure in Particle 513-SP04: buffer fracture with kernel protrusion $\rightarrow$ buffer/IPyC delamination $\rightarrow$ IPyC crack $\rightarrow$ IPyC/SiC delamination $\rightarrow$ fission product concentration and $\mathrm{SiC}$ degradation at the bottom of image. 

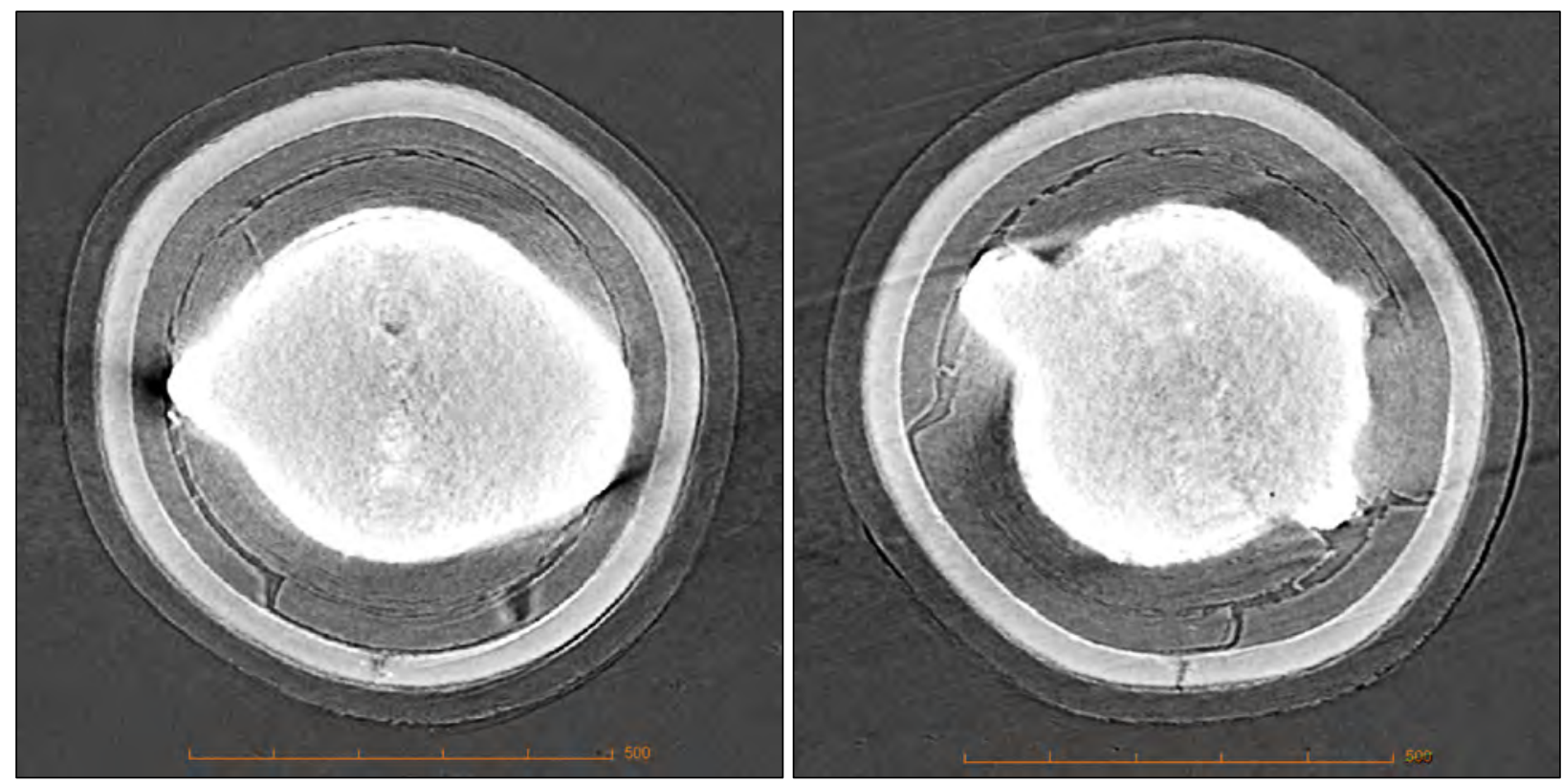

Figure 26. Pair of orthogonal x-ray tomographs showing region of SiC failure in Particle 513-SP05: buffer fracture with kernel protrusion $\rightarrow$ buffer/IPyC delamination $\rightarrow$ IPyC crack $\rightarrow$ IPyC/SiC delamination $\rightarrow$ fission product concentration and $\mathrm{SiC}$ degradation at the bottom of image.
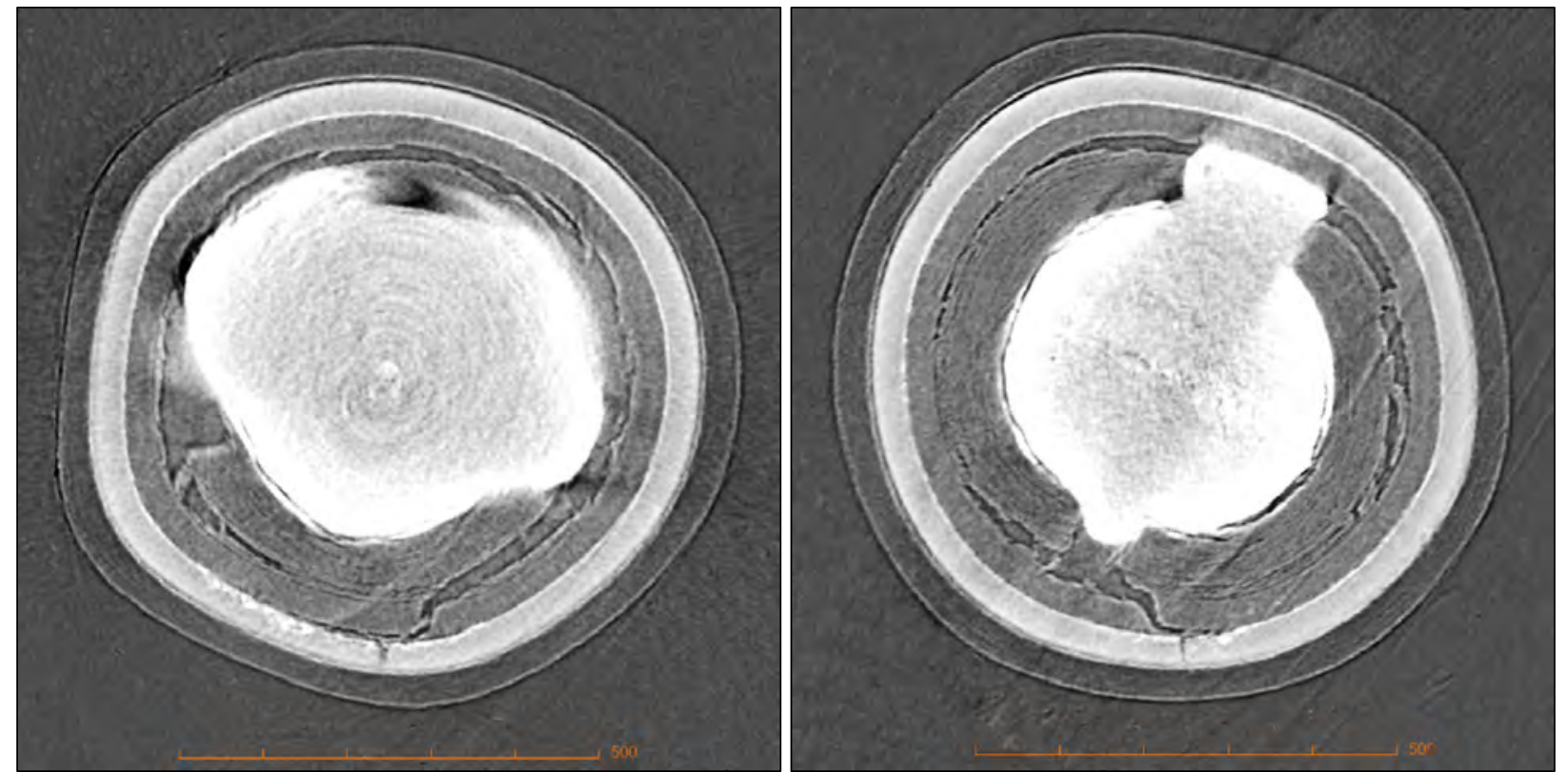

Figure 27. Pair of orthogonal x-ray tomographs showing region of SiC failure in Particle 513-SP06: buffer fracture with kernel protrusion $\rightarrow$ buffer/IPyC delamination $\rightarrow$ IPyC crack $\rightarrow$ IPyC/SiC delamination $\rightarrow$ fission product concentration and $\mathrm{SiC}$ degradation at the bottom of image. 

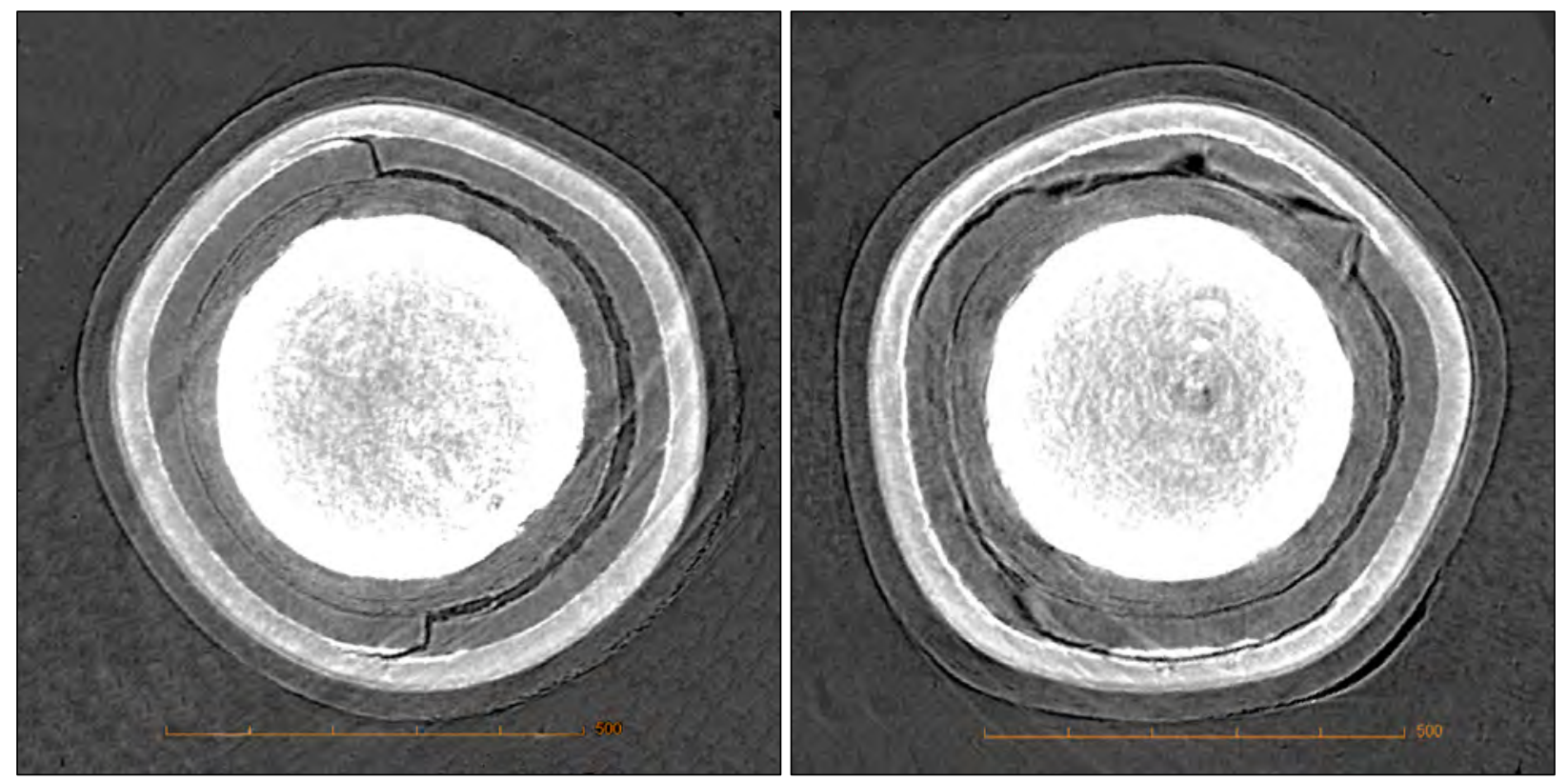

Figure 28. Pair of orthogonal x-ray tomographs showing possible region of SiC failure in Particle 513SP07: buffer/IPyC delamination $\rightarrow$ IPyC crack $\rightarrow$ IPyC/SiC delamination and tangential SiC crack $\rightarrow$ fission product concentration and $\mathrm{SiC}$ degradation at the bottom of image.

Nine of the Compact 3-2-3 specially-selected particles listed in Table 8 (Particles 323-SP01-SP08 and SP10) also had reduced cesium inventories presumably resulting in the cesium release detected during safety testing (Figure 5). Like those from Compact 5-1-3, these particles also exhibited the key radiationdamage structural features that lead to $\mathrm{SiC}$ failure - a crack through the IPyC layer that was induced by dimensional changes in the buffer and localized degradation of the $\mathrm{SiC}$ where it was exposed by the IPyC crack. Figure 29-Figure 37 show the nine failed-SiC particles from Compact 3-2-3 in two orthogonal midplanes with the failed $\mathrm{SiC}$ region located at the bottom of each image.

As already noted, kernel protrusion appeared to be particularly prevalent in Compact 3-2-3; all nine of the cesium-releasing particles had significantly protruding kernels that, in most cases, were in contact with the IPyC layer over an extended area. Some particles, such as Particle 323-SP03 (Figure 31), had kernels protruding into the IPyC crack itself, and Particle 323-SP06 had a portion of the kernel protruding all the way to the $\mathrm{SiC}$ layer (Figure 34). (Four out of five Compact 5-1-3 particles with failed SiC also exhibited kernel protrusion out to the IPyC.) Unlike the Compact 5-1-3 failed-SiC particles, which tended to have IPyC/SiC delamination leading to the $\mathrm{SiC}$ degradation, Compact 3-2-3 failed-SiC particles tended to have $\mathrm{SiC}$ degradation sites directly in line with the IPyC crack (note this observation is usually only evident in one of the two orthogonal images shown in each figure below). It is interesting to note that, in nearly every particle from these compacts with failed $\mathrm{SiC}$, there was only a single spot where the $\mathrm{SiC}$ degradation penetrated the layer, regardless of the number or extent of IPyC cracks. Fission products were typically concentrated along the IPyC crack, with onset of degradation evident along this line, but degradation deeper into the layer tended to be concentrated in one spot. Figure 33 is a good example, where the left-hand image is oriented perpendicular to the IPyC crack, while the right hand image is parallel and slightly offset from the crack (the IPyC crack is not visible, but the line of fission products and near-interface degradation associated with the crack lie in the image plane).

Particle 323-SP01 deviated from the general trends for failed-SiC particles from Compact 3-2-3 (Figure 29). This particle exhibited less kernel protrusion and more IPyC/SiC delamination, with one delamination leading to an unusually-deep tangential crack in the SiC (Figure 29a). The through-layer defect responsible for cesium release appeared to be located along this tangential crack, and it is not clear from the x-ray tomography whether the penetration at this site was due to radial cracking or corrosion of the remaining $\mathrm{SiC}$. This particle also had a more obvious $\mathrm{SiC}$ degradation site on the opposite side of the 
particle that was more typical of the penetrations in the other Compact 3-2-3 particles with failed SiC, but this degradation did not appear to go all the way through the layer (Figure 29b).
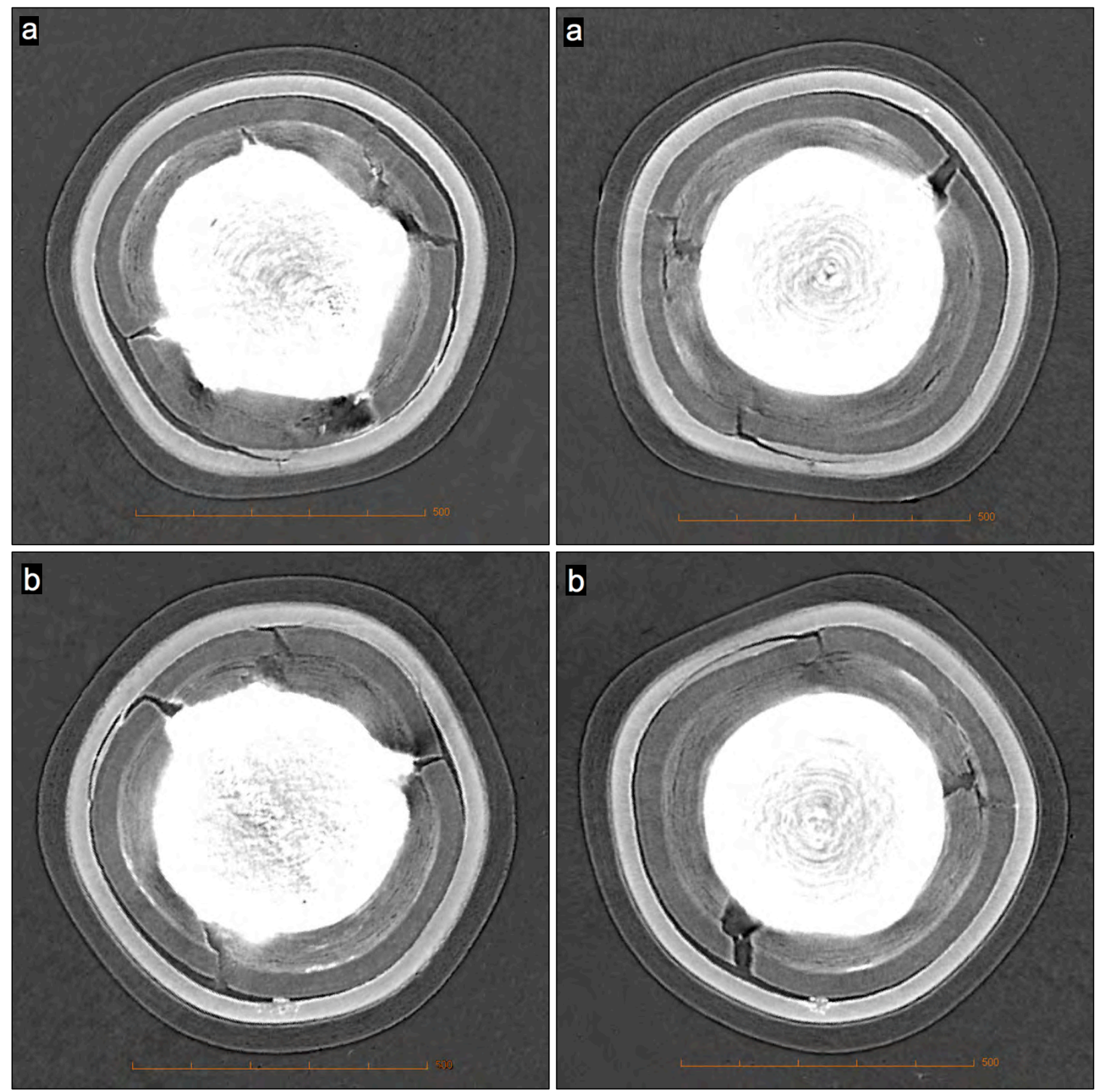

Figure 29. Two pairs of orthogonal x-ray tomographs showing two possible regions of SiC failure in Particle 323-SP01: a) buffer fracture with kernel protrusion $\rightarrow$ IPyC crack $\rightarrow$ IPyC/SiC delamination $\rightarrow$ tangential $\mathrm{SiC}$ crack $\rightarrow$ radial $\mathrm{SiC}$ crack or $\mathrm{SiC}$ degradation at the bottom of image, and $\mathrm{b}$ ) buffer fracture $\rightarrow \mathrm{IPyC}$ crack $\rightarrow \mathrm{IPyC} / \mathrm{SiC}$ delamination $\rightarrow$ fission product concentration and $\mathrm{SiC}$ degradation at the bottom of image. Note that Figure $29 \mathrm{~b}$ corresponds to $\sim 160^{\circ}$ clockwise rotation of Figure 29a plus a small out of plane rotation; the edge of the degraded region at the bottom of Figure 29b can be seen in the upper right quadrant of Figure 29a. 

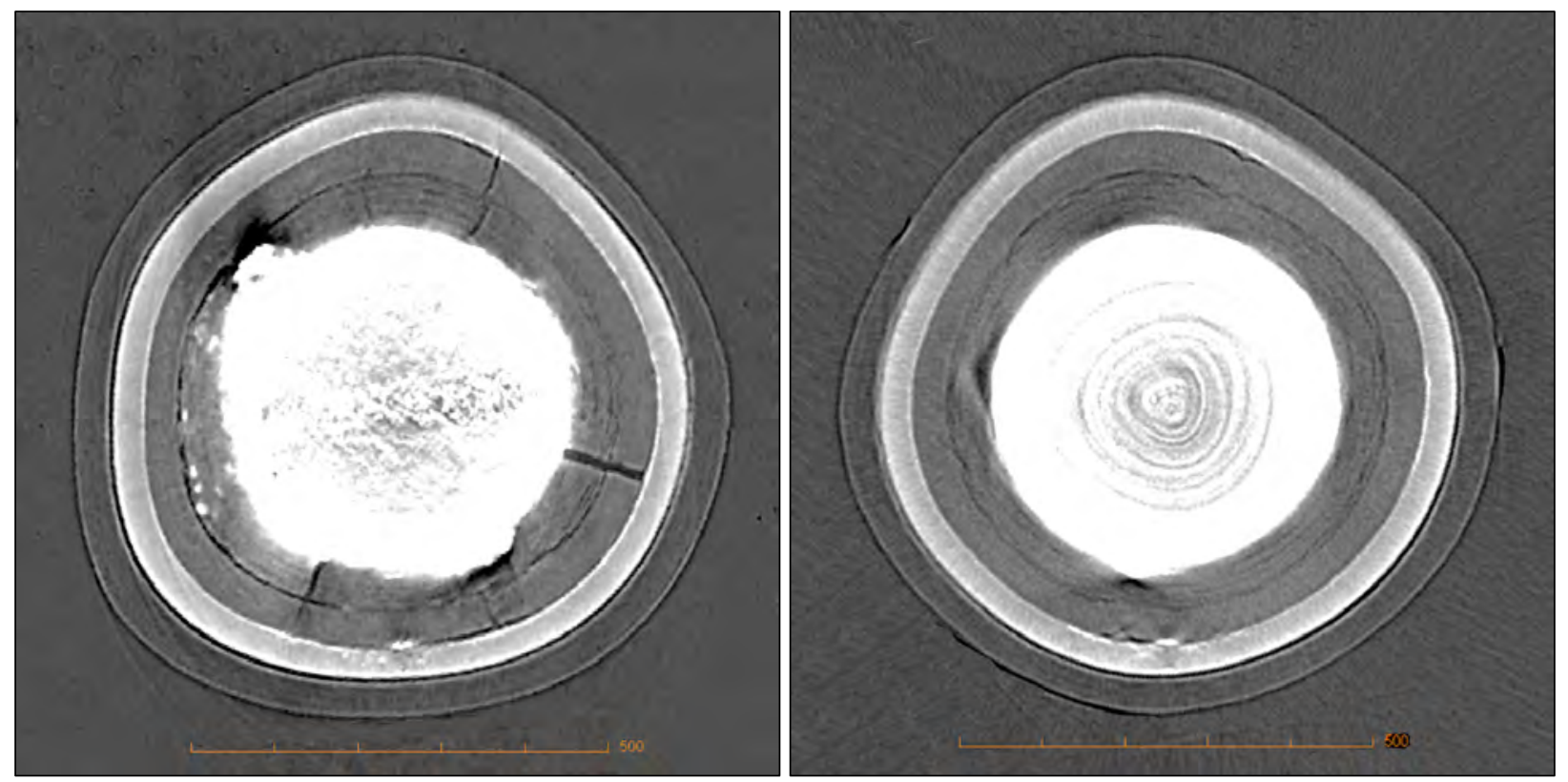

Figure 30. Pair of orthogonal x-ray tomographs showing regions of SiC failure in Particle 323-SP02: buffer fracture $\rightarrow$ IPyC crack $\rightarrow$ IPyC/SiC delamination $\rightarrow$ fission product concentration and $\mathrm{SiC}$ degradation at the bottom of image.
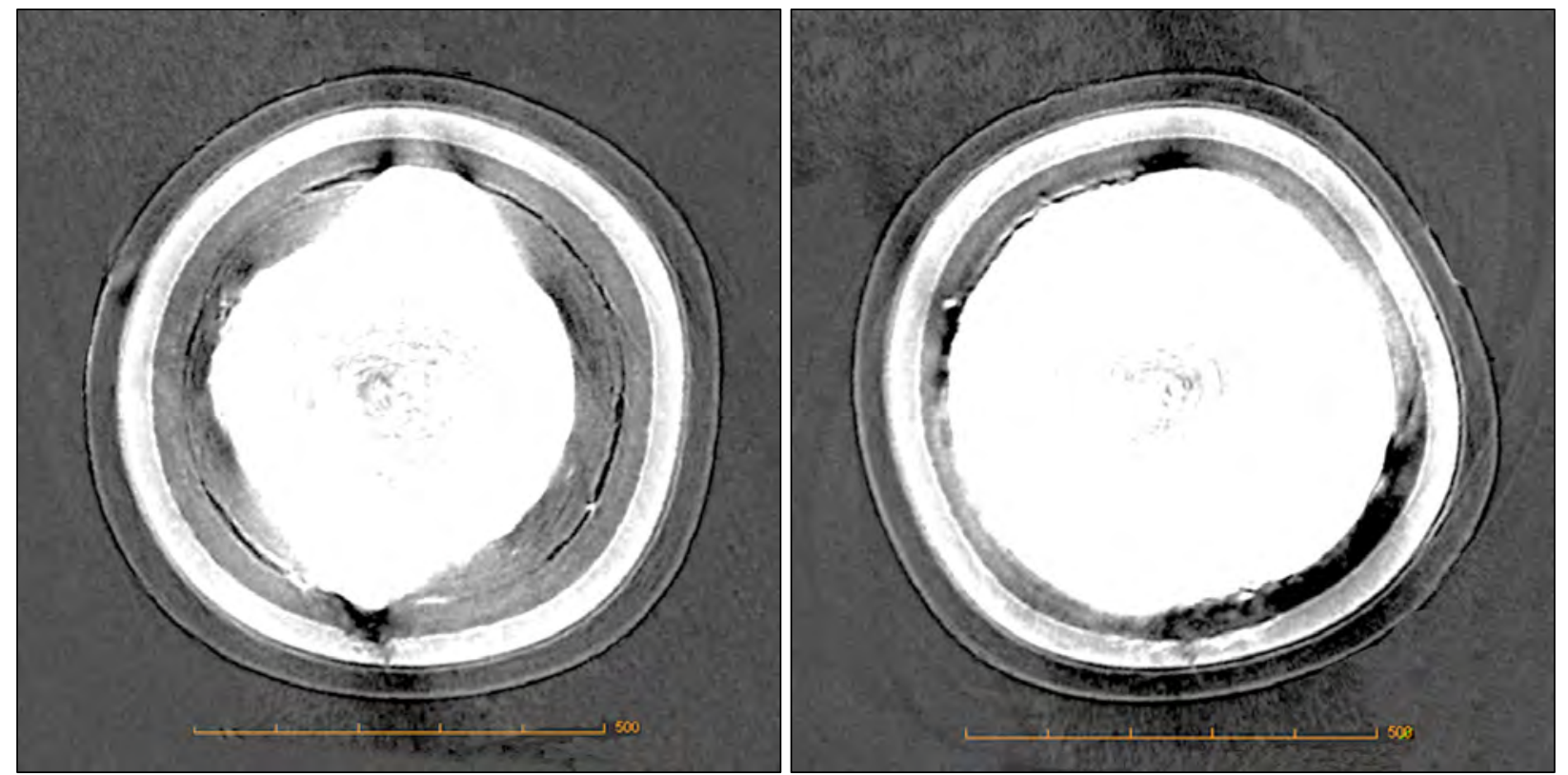

Figure 31. Pair of orthogonal x-ray tomographs showing regions of SiC failure in Particle 323-SP03: buffer fracture with significant kernel protrusion $\rightarrow$ IPyC crack with kernel protrusion $\rightarrow$ fission product concentration and $\mathrm{SiC}$ degradation at the bottom of image. 

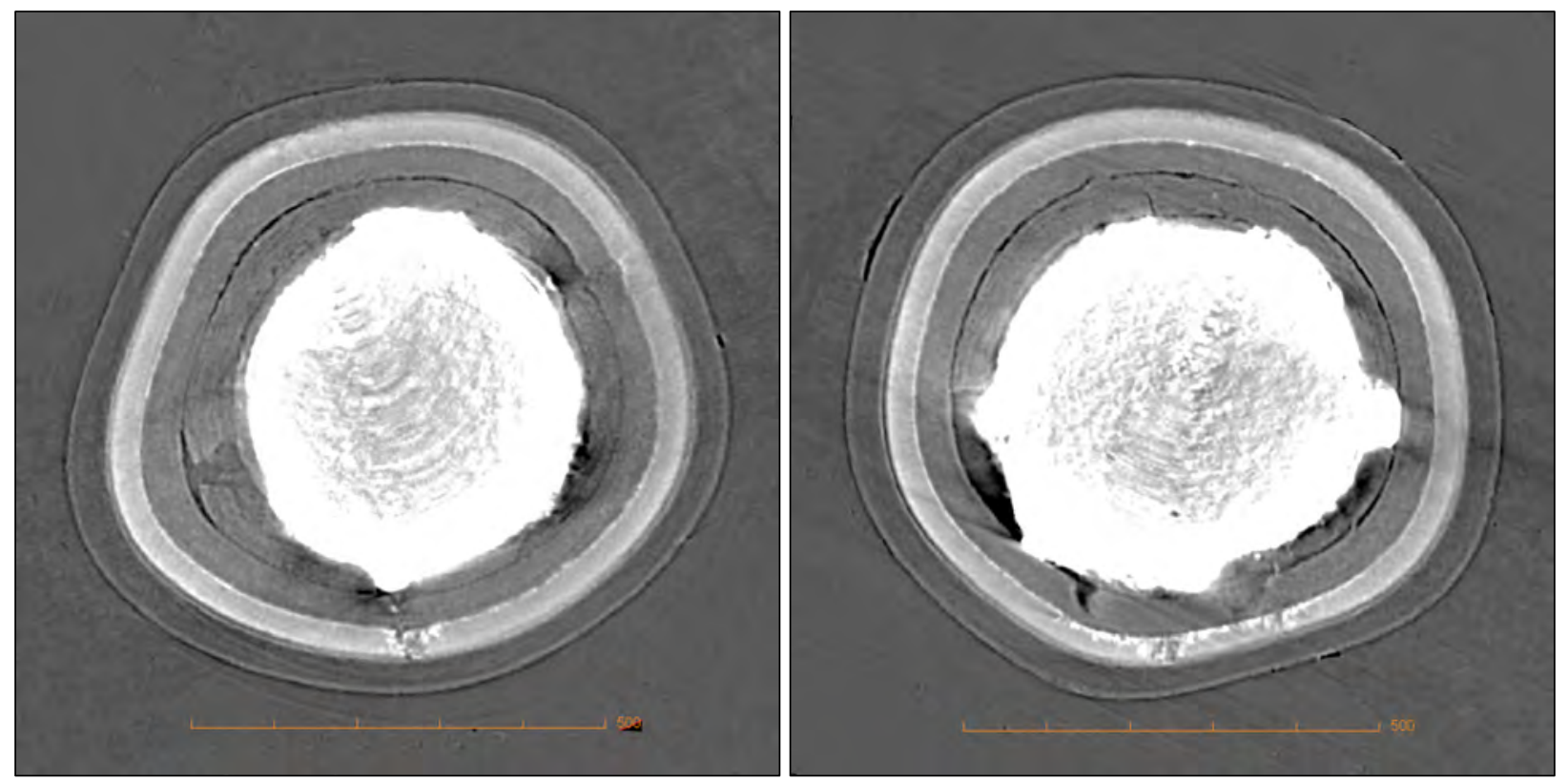

Figure 32. Pair of orthogonal x-ray tomographs showing regions of SiC failure in Particle 323-SP04: buffer fracture with kernel protrusion $\rightarrow$ IPyC crack $\rightarrow$ fission product concentration and SiC degradation at the bottom of image.
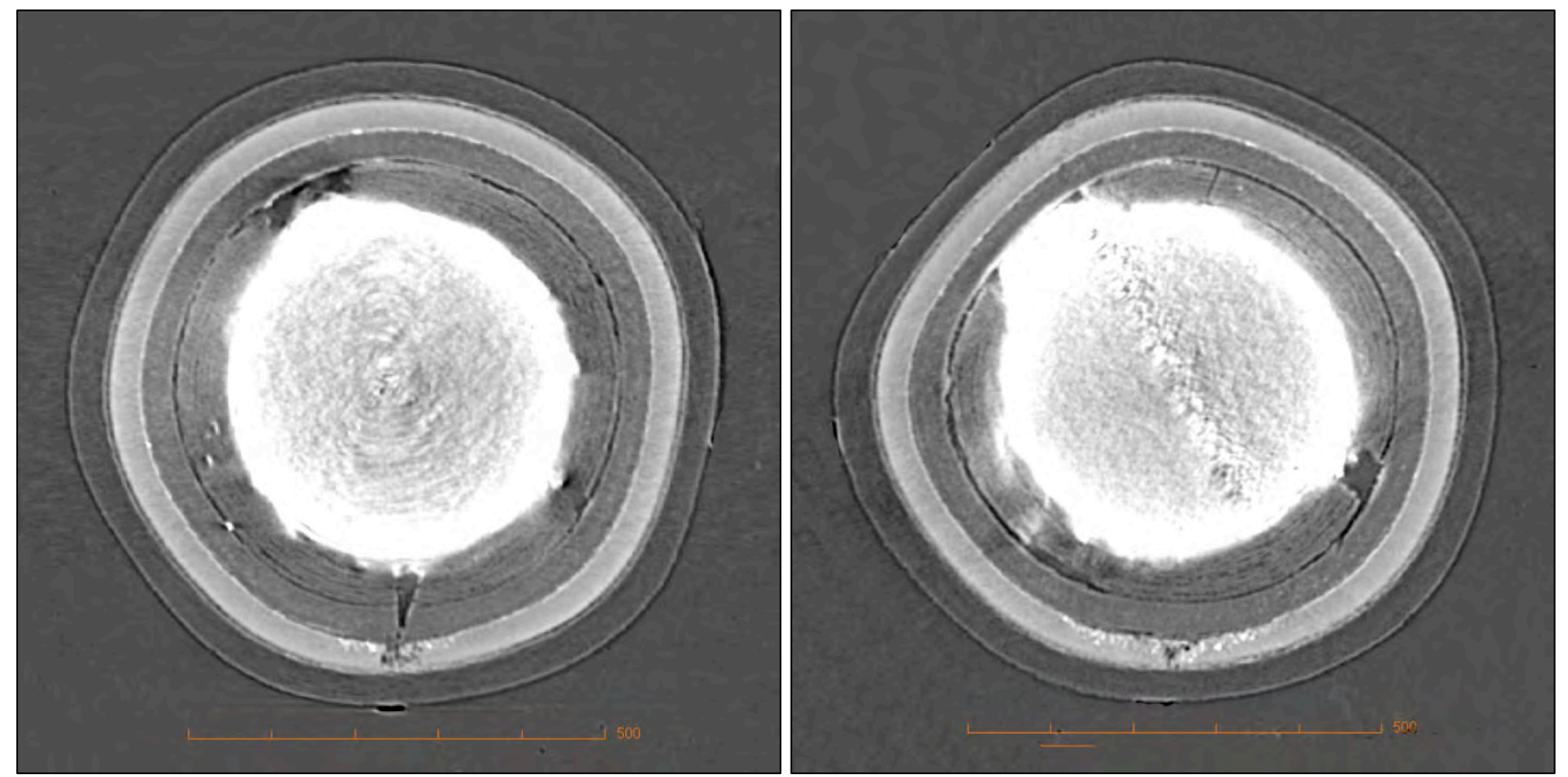

Figure 33. Pair of orthogonal x-ray tomographs showing regions of SiC failure in Particle 323-SP05: buffer fracture with kernel protrusion $\rightarrow$ IPyC crack $\rightarrow$ fission product concentration and SiC degradation at the bottom of image. 

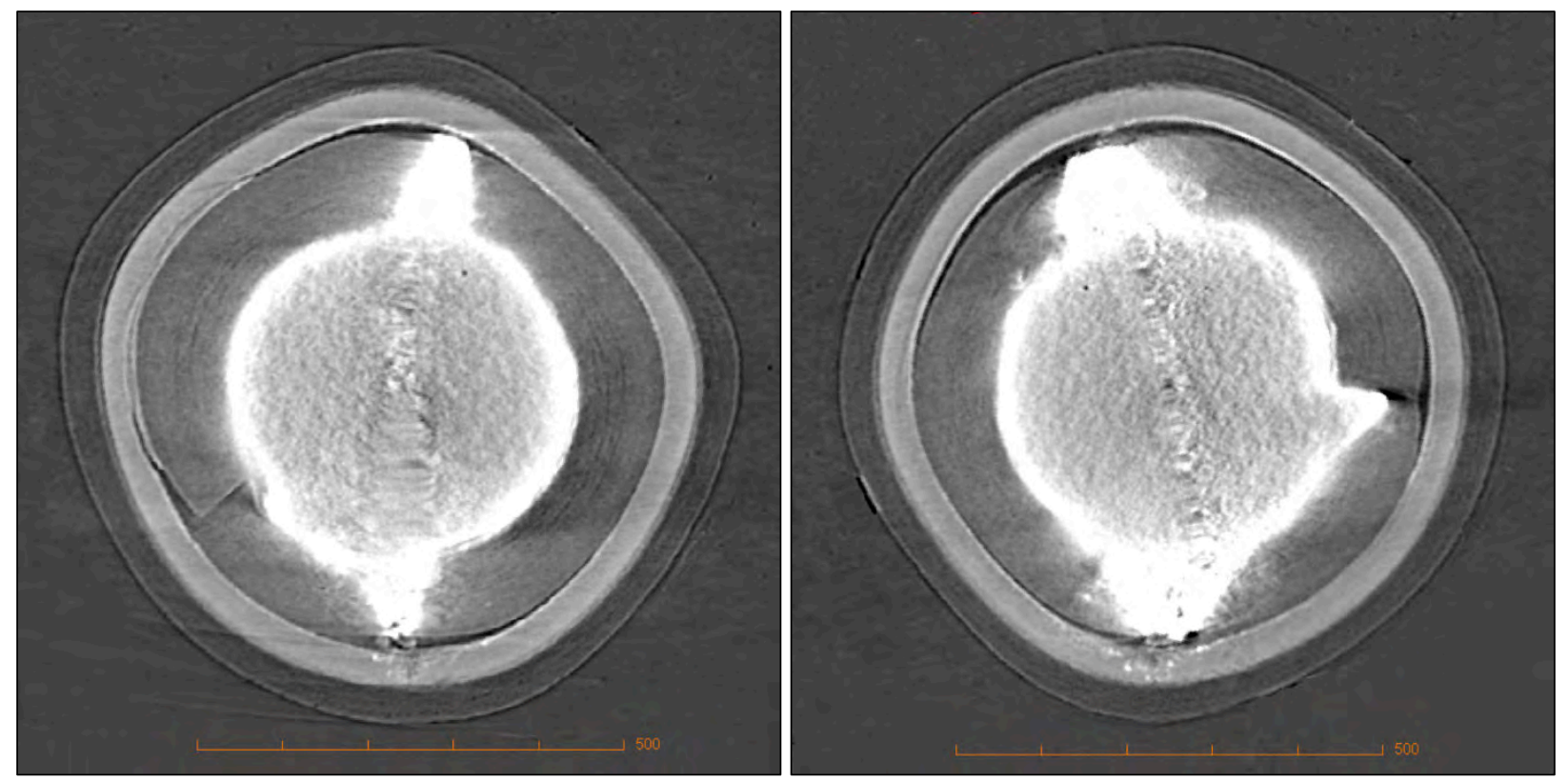

Figure 34. Pair of orthogonal x-ray tomographs showing regions of SiC failure in Particle 323-SP06: buffer fracture with kernel protrusion $\rightarrow$ IPyC crack with kernel protrusion $\rightarrow$ fission product concentration and $\mathrm{SiC}$ degradation at the bottom of image.
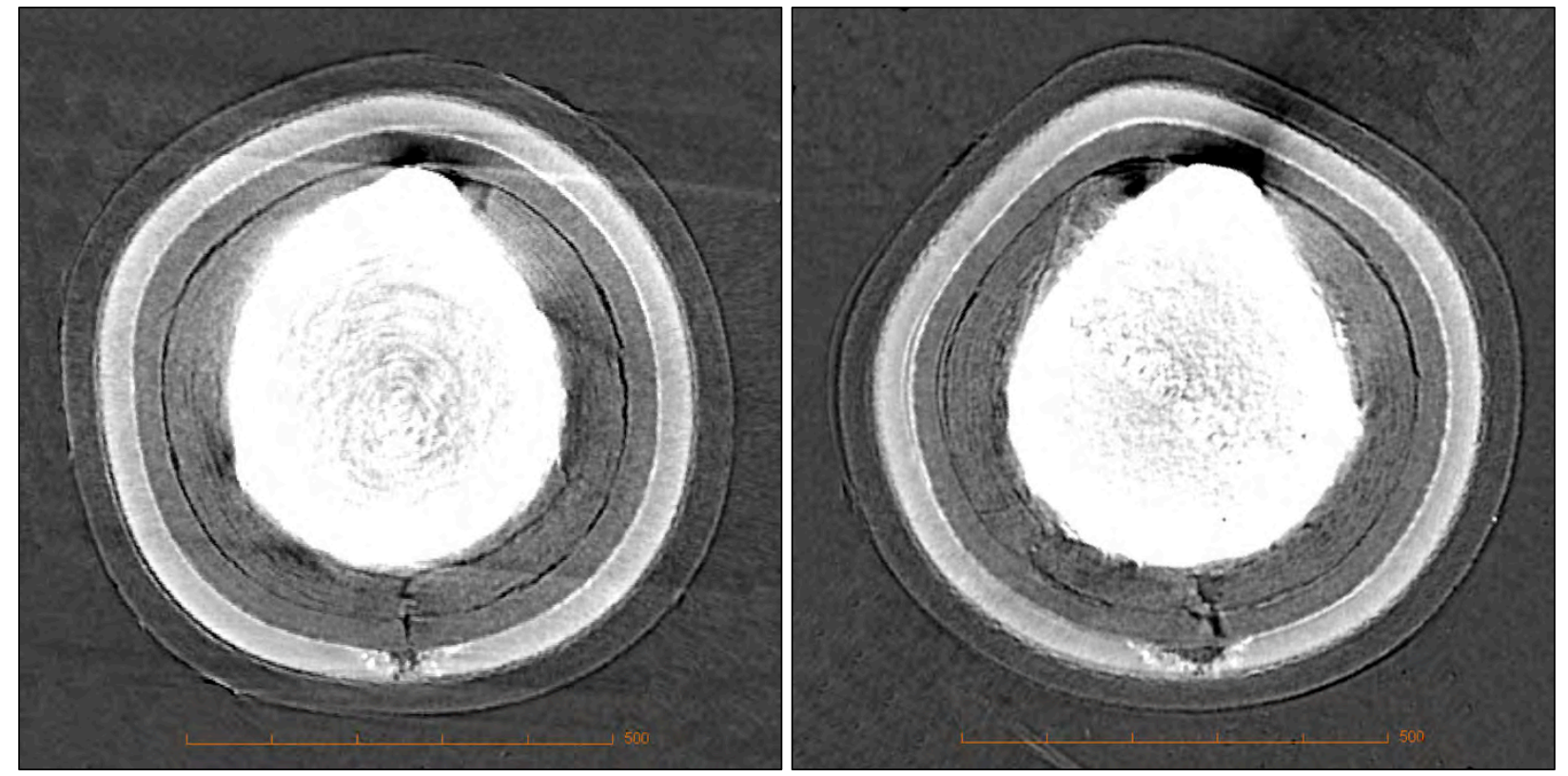

Figure 35. Pair of orthogonal x-ray tomographs showing regions of SiC failure in Particle 323-SP07: buffer fracture $\rightarrow$ IPyC crack $\rightarrow$ fission product concentration and $\mathrm{SiC}$ degradation at the bottom of image. 

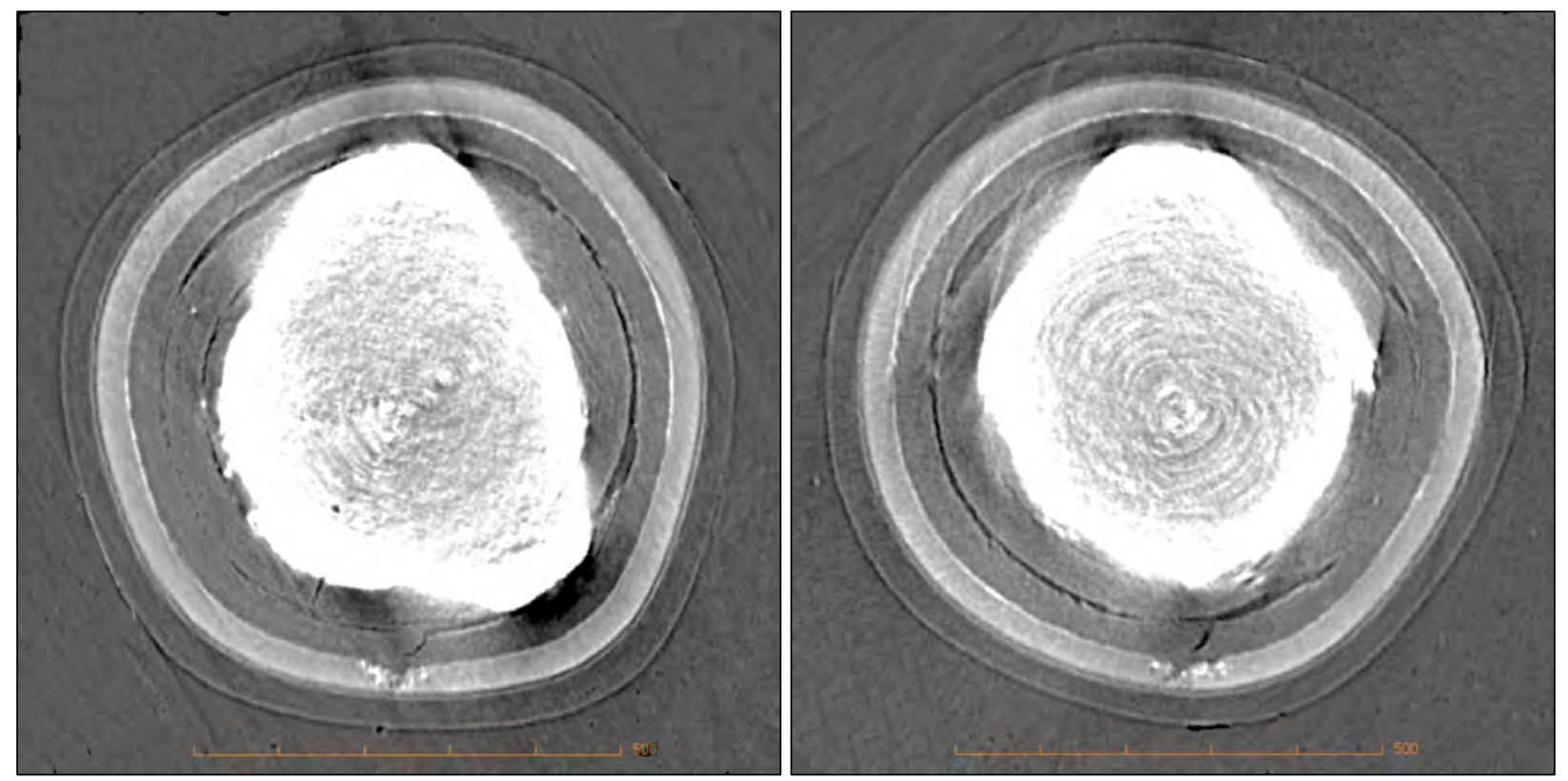

Figure 36. Pair of orthogonal x-ray tomographs showing regions of $\mathrm{SiC}$ failure in Particle 323-SP08: buffer fracture $\rightarrow$ IPyC crack $\rightarrow$ IPyC/SiC delamination $\rightarrow$ fission product concentration and $\mathrm{SiC}$ degradation at the bottom of image.
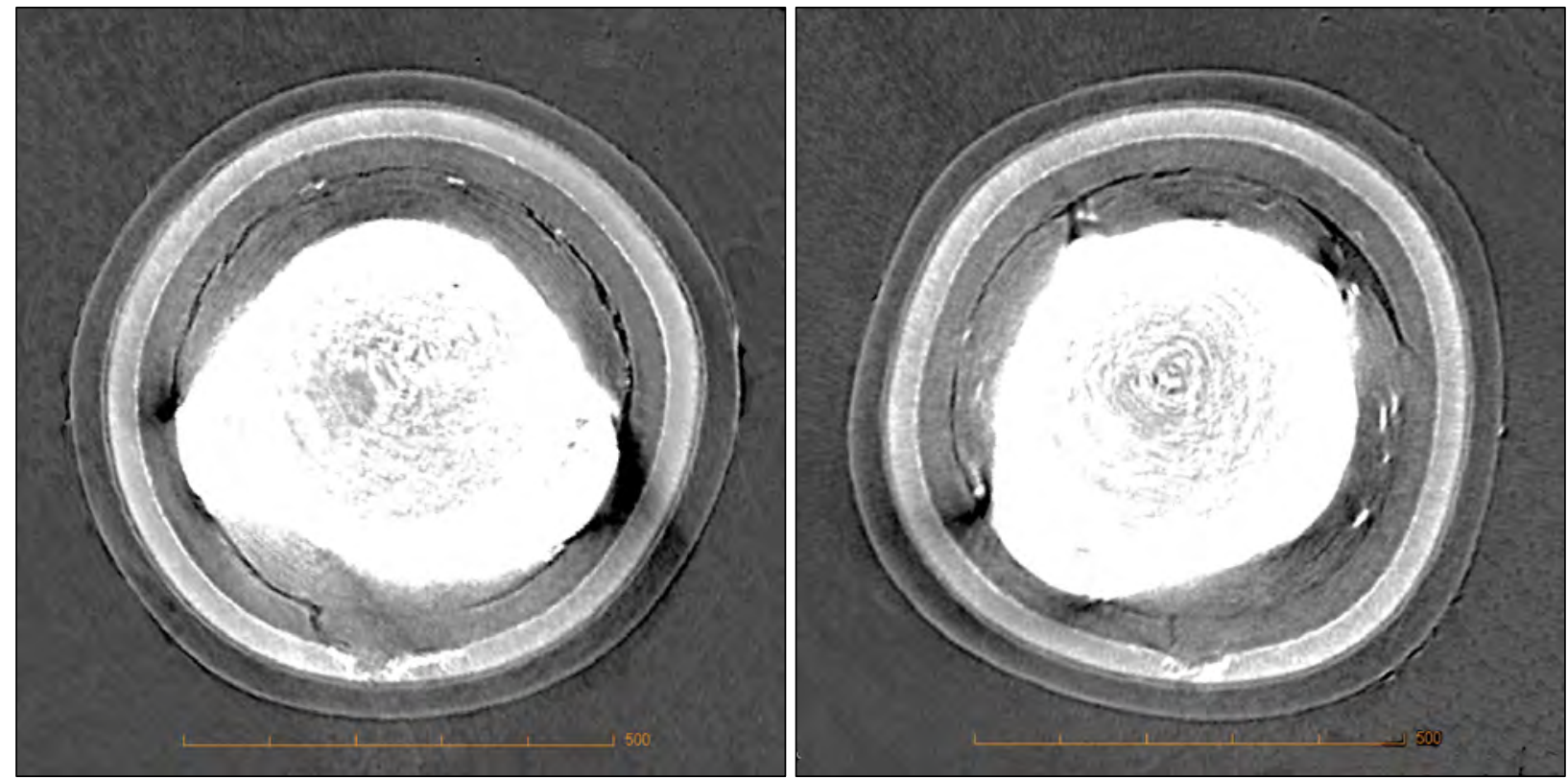

Figure 37. Pair of orthogonal x-ray tomographs showing regions of SiC failure in Particle 323-SP09: buffer fracture with kernel protrusion $\rightarrow$ buffer/IPyC delamination $\rightarrow$ IPyC crack $\rightarrow$ IPyC/SiC delamination $\rightarrow$ fission product concentration and $\mathrm{SiC}$ degradation at the bottom of image. 
After x-ray imaging, several of the specially-selected particles were mounted in epoxy and ground down to reveal the $\mathrm{SiC}$ degradation or some other region of interest. This allowed further study of these features, including identification of fission product clusters associated with the $\mathrm{SiC}$ attack. The process whereby the three-dimensional $\mathrm{x}$-ray tomography is used to orient and guide the preparation of polished sections such that the region of interest can be revealed for analysis is described and illustrated in Figure 166 of the AGR-1 Irradiated Compacts 5-2-3 and 5-2-1 PIE Report [Hunn et al. 2014-1]; (these were two compacts where as-irradiated $\mathrm{SiC}$ failure was observed and studied).

Figure 38a is an x-ray tomograph showing the target analysis plane in Particle 323-SP05 and Figure 38b is an optical micrograph of the final polished surface of the materialographic mount. This target analysis plane was chosen because it passed through the degraded-SiC region and was perpendicular to the vertical axis of the particle (as held in the x-ray mount); the vertical $\mathrm{x}$-ray axis is a convenient axis to grind down because it is easy to fix the particle in this orientation in the materialographic mounting form. Figure 38 shows the IPyC crack and degraded SiC region surrounded by fission products. Because this polish plane did not require grinding through the IPyC and exposing the buffer/kernel region, vacuum back-potting was not required and the degraded region could be examined without interference from the epoxy. (Vacuum backpotting is usually required to prevent redistribution and crumbling of the buffer and kernel, which are often fractured and/or detached from the outer coating layers.)
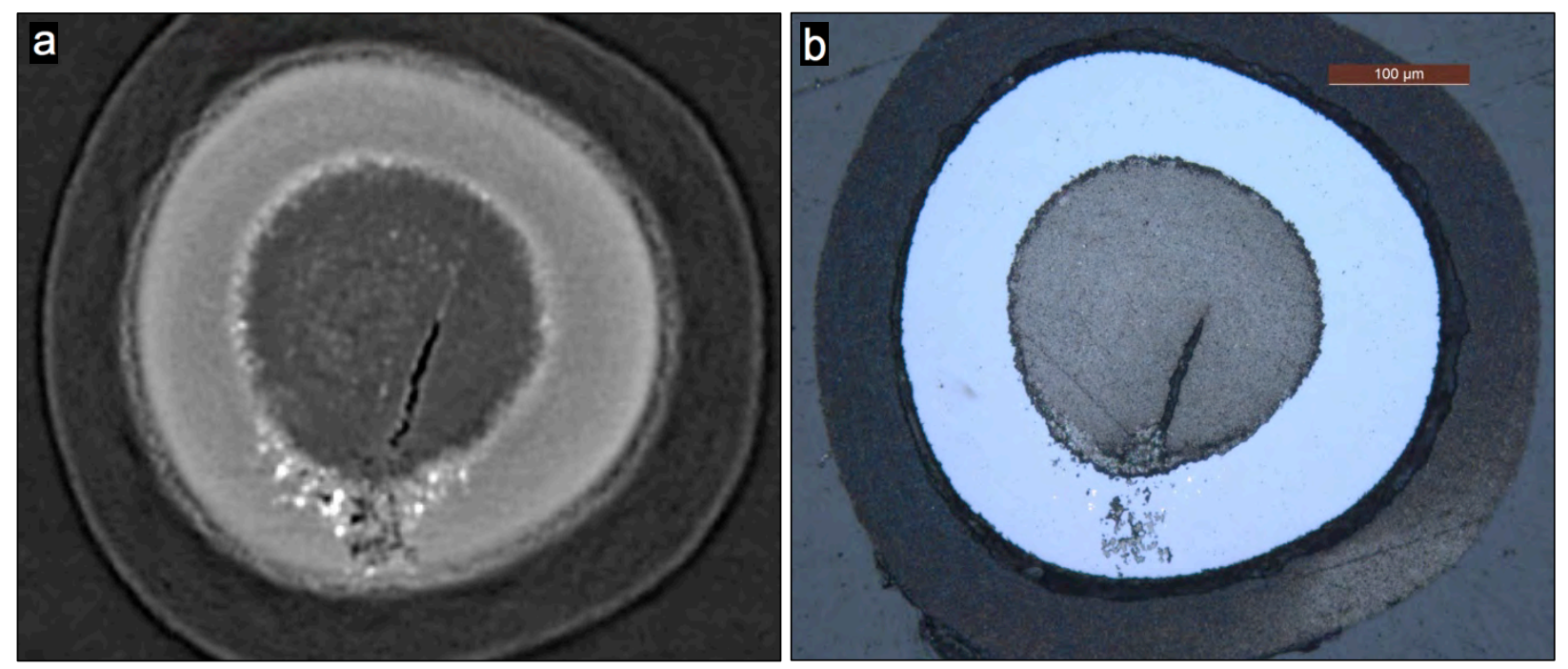

Figure 38. SiC failure in Particle 323-SP05, which released cesium (Table 8): a) x-ray tomograph prior to sectioning and b) optical micrograph of polished section.

Figure 39 shows a pair of secondary and backscattered electron images of the degraded region in Particle 323-SP05. The low density regions evident in the x-ray images of the degraded SiC were either vacant or filled with carbon-rich material (compared to the surrounding $\mathrm{SiC}$ ). It is unclear whether the regions where material was absent were truly voids inside the SiC layer or simply where carbon material had been removed by the grinding and polishing process. Smaller regions tended to be completely filled with the carbon-rich material. Presumably, outward migration of silicides at safety test temperatures was responsible for the formation of the carbon-rich zones. The degraded $\mathrm{SiC}$ region was surrounded by relatively larger and more numerous clusters of palladium and uranium, compared to other location in the $\mathrm{SiC}$ layer. 


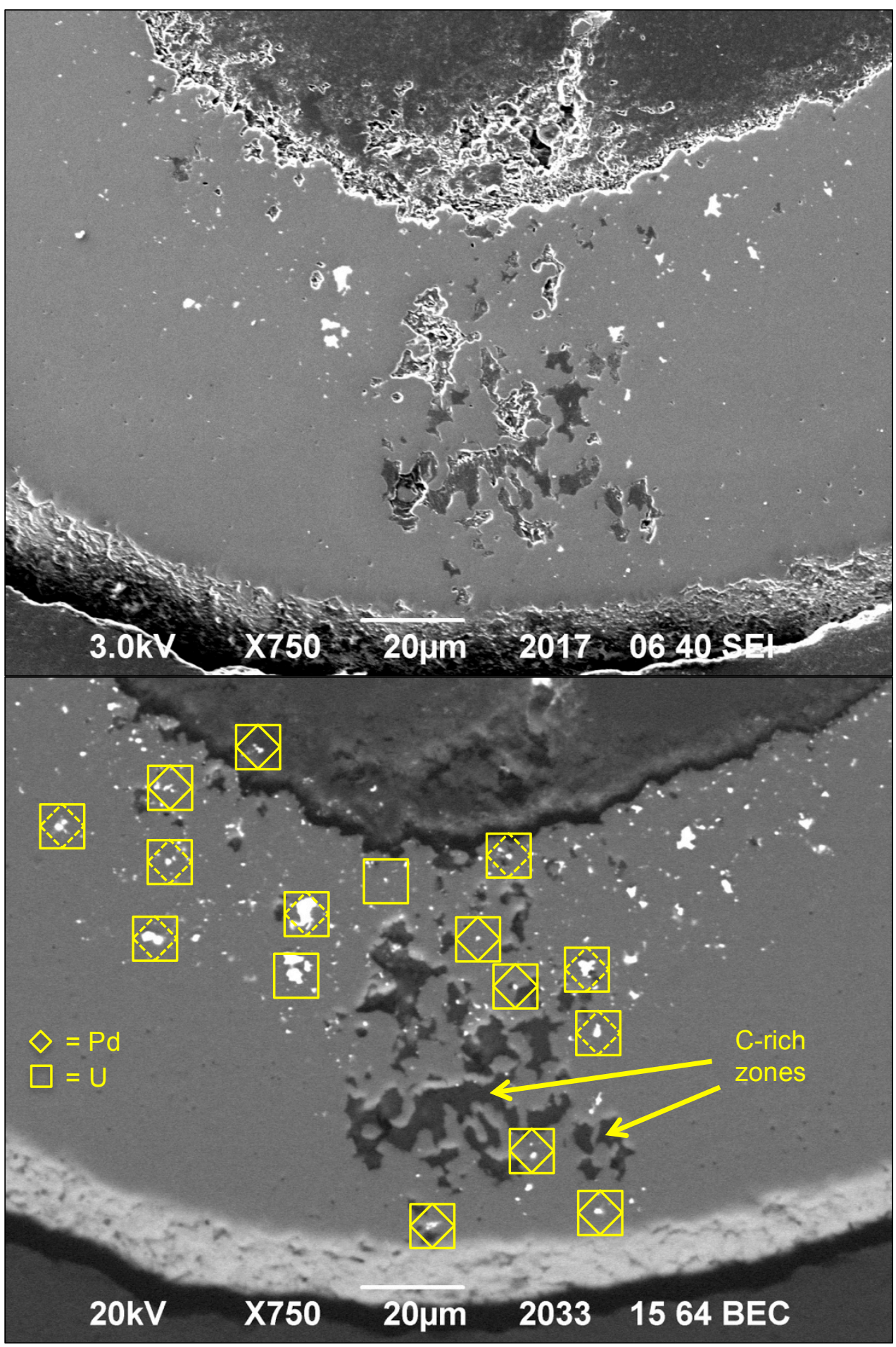

Figure 39. SEI/BEC-paired images of SiC region in Compact 3-2-3 Particle 323-SP05, which released cesium (Table 8). Dashed diamonds or squares indicate relatively less Pd or U were detected.

Figure 40 shows an SEI/BEC pair of SEM images of the degraded region in Particle 323-SP08. Observation were similar to those above. Large carbon-rich zones remained where the $\mathrm{SiC}$ had been degraded, with palladium and uranium decorating the surrounding region. 


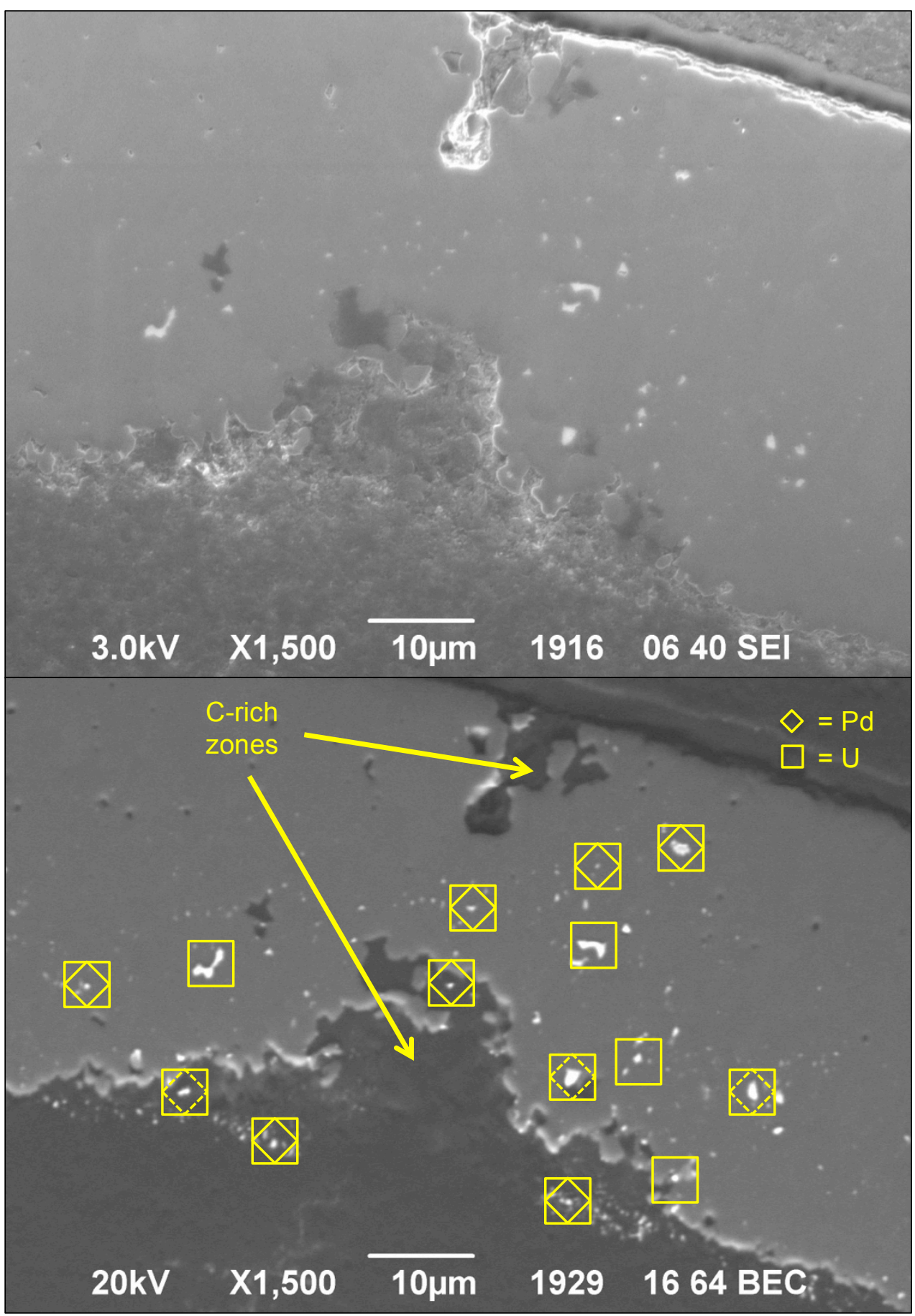

Figure 40. SEI/BEC-paired images of SiC region in Compact 3-2-3 Particle 323-SP08, which released cesium (Table 8). Dashed diamonds or squares indicate relatively less Pd or U were detected.

\section{ENUMERATION OF PARTICLES WITH FAILED SIC}

Determination of the number of particles in each compact with failed $\mathrm{SiC}$ was discussed in a summary paper describing the detection and analysis of all the failed-SiC particles detected in AGR-1 irradiation testing and post-irradiation safety testing [Hunn et al. 2014-2]. The method was based on summing the amount of cesium released from the compact (measured with the CCCTF), the amount of exposed cesium still in the compact outside of intact SiC layers (measured by DLBL), and the amount of cesium retained by the particles with failed $\mathrm{SiC}$ that were separated out and measured with the IMGA. A second method 
was considered for comparison that involved counting the low-cesium retaining particles found with IMGA that $\mathrm{x}$-ray examination determined to have degraded $\mathrm{SiC}$ and adding in an estimate of the number of particles that were broken during the deconsolidation, leaching, and sieving prior to IMGA survey, based on the detection of uranium from exposed kernels. Table 9 and Table 10 show the enumeration results for Compacts 5-1-3 and 3-2-3.

Table 9. Estimation of the number of particles with failed SiC based on recovery of ${ }^{134} \mathrm{Cs}$

\begin{tabular}{|l|c|c|}
\hline & Compact 5-1-3 & Compact 3-2-3 \\
\hline Number of particles worth of ${ }^{134} \mathrm{Cs}$ detected in CCCTF outside compact & 4.87 & 6.62 \\
\hline Number of particles worth of ${ }^{134} \mathrm{Cs}$ detected by DLBL & 0.10 & 0.33 \\
\hline Number of particles worth of ${ }^{134} \mathrm{Cs}$ retained in particles found with IMGA & 2.18 & 3.93 \\
\hline $\begin{array}{l}\text { Total number of particles worth of }{ }^{134} \mathrm{Cs} \text { presumed to be associated with } \\
\text { particles that released }{ }^{134} \mathrm{Cs} \text { through failed SiC }\end{array}$ & 7.15 & 10.89 \\
\hline Estimated number of particles with failed SiC based on ${ }^{\mathbf{1 3 4}} \mathrm{Cs}$ accounting & $\mathbf{7}$ & $\mathbf{1 1}$ \\
\hline
\end{tabular}

${ }^{134} \mathrm{Cs}$ detected in post-burn leach of particles analyzed after IMGA survey was not included because a few particles with normal cesium retention were broken by the process and particles with failed $\mathrm{SiC}$ had already been removed from sample and accounted for with IMGA.

Table 10. Estimation of the number of particles with failed SiC based on counting with IMGA and DLBL

\begin{tabular}{|c|c|c|}
\hline & Compact 5-1-3 & Compact 3-2-3 \\
\hline Number of particles with failed SiC found with IMGA & 5 & 9 \\
\hline Number of particles worth of ${ }^{235} \mathrm{U}$ detected by DLBL & 1.25 & 1.91 \\
\hline Estimated number of particles with failed $\mathrm{SiC}$ detected by DLBL & 1 & 2 \\
\hline Estimated total number of particles detected by the IMGA and DLBL & 6 & 11 \\
\hline
\end{tabular}

${ }^{235} \mathrm{U}$ detected in post-burn leach of particles analyzed after IMGA survey was not included because a few particles with normal cesium retention were broken by the process and particles with failed $\mathrm{SiC}$ had already been removed from sample and accounted for with IMGA.

Agreement between the two enumeration methods was generally excellent for most of the AGR-1 compacts [Hunn et al. 2014-2]. However, the ${ }^{134} \mathrm{Cs}$ summation method estimated one more particle with failed SiC in Compact 5-1-3 (Table 9) than could be accounted for using the second counting method (Table 10). This enumeration discrepancy may simply be due to measurement uncertainty and the impact of background contamination from the hot cell environment, or it could be due to particles with failed $\mathrm{SiC}$ being missed by the IMGA survey. One possibility would be that one of the 23 Compact 5-1-3 particles mentioned in the IMGA results section above as being lost during transport of particles between the IMGA storage-vial station and the gamma-counting station was a particle that had released most of its cesium. Such a particle would have contributed enough to the amount of ${ }^{134} \mathrm{Cs}$ detected in the CCCTF to be counted by the cesium summation method (Table 9), but not included in the second counting method (Table 10). Another possibility would be that there was a population of particles with SiC degradation that only released a small fraction of their cesium. Because the IMGA survey is only intended to separate out particles with cesium inventory clearly outside the normal distribution about the mean, particles with low cesium release but cesium/cerium ratios that put them in the main distribution would not usually be identified as having released cesium. Unidentified particles with low-cesium release would not be included in the second counting method (Table 10) and only partly contribute to the cesium summation method (Table 9) because the cesium remaining in the particles would not be added in. In the data summarized in Table 9 and Table 10, if ten additional particles each released only $10 \%$ of their ${ }^{134} \mathrm{Cs}$ and these particles had been included in the enumeration, this would have added nine more particles worth of ${ }^{134} \mathrm{Cs}$ to the cesium summation in Table 9 and ten more particles to the total in Table 10, increasing both estimates to sixteen. Given the width of the ${ }^{137} \mathrm{Cs} /{ }^{144} \mathrm{Ce}$ distributions in Figure 6 and Figure 7, it would be difficult and time-consuming to use IMGA to separate out particles with such a low cesium release; so if these particles exist, it may not be feasible to include them in the enumeration of particles with failed SiC. 


\section{SUMMARY AND CONCLUSIONS}

This report summarizes the safety testing and post-safety testing PIE of AGR-1 Compacts 5-3-3, 5-1-3, and 3-2-3. Safety tests were performed at $1600^{\circ} \mathrm{C}$ on Compact 5-3-3 and $1800^{\circ} \mathrm{C}$ on Compacts 5-1-3 and 3-2-3. These were the last three standard AGR-1 safety tests performed in the ORNL CCCTF. Post-safety testing PIE consisted of DLBL, IMGA, x-ray tomography, and materialographic inspection by mechanical cross sectioning followed by optical and electron microscopy. Data was obtained on radioisotope retention and microstructural changes that occurred during irradiation and the subsequent safety testing.

None of the safety tests resulted in significant ${ }^{85} \mathrm{Kr}$ release, indicating that at least one of the three gastight outer layers of the TRISO coating on each particle (IPyC, $\mathrm{SiC}$, or $\mathrm{OPyC}$ ) remained intact throughout the duration of each test. No significant cesium release was observed during the $1600^{\circ} \mathrm{C}$ safety test of Compact 5-3-3 (Figure 2), indicating that all particles had intact $\mathrm{SiC}$ layers. In the $1800^{\circ} \mathrm{C}$ tests of Compacts 5-1-3 and 3-2-3, cesium release was detected from particles with failed SiC (Figure 5). Postsafety test analysis indicated that Compact 5-1-3 had six or seven particles with through-layer SiC degradation that resulted in a significant cesium release, and Compact 3-2-3 had eleven (Table 9 and Table 10); most of these were successfully detected and sorted out during IMGA survey of the particles deconsolidated from the safety-tested compacts (Figure 6 and Figure 7), but a few were apparently broken while separating particles from the compact matrix prior to the IMGA survey. The recovered particles with failed $\mathrm{SiC}$ were subjected to further gamma scanning and microstructural analysis.

Individual gamma counting of the particles with failed $\mathrm{SiC}$ showed that, in addition to cesium release, these particles also released silver and europium, while retaining ruthenium, antimony, and cerium. Microstructural analysis showed that the particles with failed SiC shared a similar internal microstructure that was consistent with the general trend observed in other AGR-1 particles with failed SiC [Hunn et al. 2014-2]. In these particles, dimensional changes in the buffer and kernel due to buffer densification and kernel expansion led to cracking of the IPyC layer. Two general mechanisms for IPyC cracking were buffer fracture propagating directly into the IPyC layer and buffer layer delamination resulting in damage to the IPyC as the buffer layer was torn away. IPyC cracks did not always result in $\mathrm{SiC}$ failure, but $\mathrm{SiC}$ failure appeared to always be related to IPyC cracking. Exposure of the $\mathrm{SiC}$, either along the edge of the $\mathrm{IPyC}$ crack or where the IPyC crack led to delamination at the IPyC/SiC interface, allowed fission products (predominantly palladium and uranium) to pile-up and react with the SiC layer. Degradation of the exposed $\mathrm{SiC}$ eventually resulted in a localized penetration of the layer. Removal of silicon along this penetration pathway left behind a low-density, carbon-rich material through which cesium and other elements such as silver and europium could escape. None of the particles with failed SiC exhibited krypton release indicative of a completely breached TRISO layer because the OPyC layer remained intact. Small (2-3\%) releases of ${ }^{85} \mathrm{Kr}$ over the 300-hour duration of the $1800^{\circ} \mathrm{C}$ safety tests (Table 2) were probably due to slow migration of the krypton through the intact OPyC. Most of the structural changes observed in the particles examined after safety testing probably occurred during irradiation, while the degradation of the $\mathrm{SiC}$ occurred at higher temperature during the post-irradiation safety testing. Overall enumeration of the occurrences of $\mathrm{SiC}$ failure during AGR-1 irradiation and $1600-1800^{\circ} \mathrm{C}$ safety testing showed that $\mathrm{SiC}$ degradation was present under some AGR-1 irradiation test conditions, but was greatly enhanced at $1800^{\circ} \mathrm{C}$.

Significant quantities of silver were released from the compacts during safety testing $(2-10 \%$ of the calculated inventory). Most of this release occurred very early in the safety testing and it is likely that the source of this silver was from outside of intact $\mathrm{SiC}$ layers, having been previously released through the $\mathrm{SiC}$ during the three-year irradiation. Palladium release detected in the $1800^{\circ} \mathrm{C}$ safety tests may also be coming from outside of intact $\mathrm{SiC}$ layers, but with release occurring on a slower time scale due to its lessvolatile nature. Palladium migration out of the $\mathrm{SiC}$ layer at $1800^{\circ} \mathrm{C}$ (indicated by the absence of palladium clusters in the $\mathrm{SiC}$ and the presence of carbon-rich zones where the palladium clusters likely resided at the start of the safety test) may also have contributed to the high release. Silver and palladium retention in the 
matrix and $\mathrm{OPyC}$ was relatively low in the safety-tested compacts (Table 3), in agreement with the assumption that these elements are migrating out of the compacts at high temperature.

At $1800^{\circ} \mathrm{C}$, europium and strontium release from the compacts was also high (Table 2). The fact that europium and strontium are not as well retained in the carbonaceous material at higher temperature was a contributing factor to this higher releases (Table 4), but there may also have been particle release through intact $\mathrm{SiC}$ layers, given that the amount that was released was more than what would be expected in the matrix and $\mathrm{OPyC}$ at the end of irradiation and could not be wholly accounted for by what was released from particles with failed $\mathrm{SiC}$. Additional evidence for particle release at $1800^{\circ} \mathrm{C}$ comes from comparison of the Compact 3-2-3 furnace test release to Compact 3-2-1 as-irradiated DLBL (these were adjacent compacts with nearly identical irradiation conditions), which reveals an order-of-magnitude higher europium and strontium release from Compact 3-2-3 during safety testing than what was found in the asirradiated Compact 3-2-1 matrix and OPyC.

Microstructures observed in randomly-selected particles extracted from the safety tested compacts were similar to those seen in as-irradiated fuel [Ploger, Demkowicz, and Hunn 2012; Hunn, Savage, and Kehn 2012; Hunn et al. 2013-1; Hunn et al. 2014-1]. Shrinkage of the buffer layer and swelling of the kernel were common to all particles, with the associated varied degrees of buffer/IPyC delamination and periodic cases of buffer fracture that was usually accompanied by portions of the kernel protruding into a gap between the buffer fragments. None of these microstructures seemed to be directly related to the varied amount of silver released from the particles selected for examination. The large variation in silver retention observed in the randomly-selected particles from Compacts 5-3-3, 5-1-3, and 3-2-2 (Figure 8Figure 10) was similar to that observed in other AGR-1 compacts and is believed to be primarily related to particle temperature, which varied as a function of both time and position within each compact over the three-year irradiation test [Demkowicz et al. 2014].

SEM imaging and EDS analysis of the SiC layers showed palladium and uranium were piled up in clusters at the IPyC/SiC interface and within the SiC layer itself. For Compact 5-3-3 (safety-tested at $1600^{\circ} \mathrm{C}$ ), particles with lower ${ }^{110 \mathrm{~m}} \mathrm{Ag}$ inventories had numerous clusters of palladium scattered throughout the layer, while particles with ${ }^{110 \mathrm{~m}} \mathrm{Ag}$ inventories higher than the calculated average (indicating low silver release) had $\mathrm{SiC}$ layers relatively void of palladium clusters more than $10 \mu \mathrm{m}$ away from the IPyC/SiC interface. Uranium tended to be constrained to clusters close to the IPyC/SiC interface, and uranium in the $\mathrm{SiC}$ was typically collocated with palladium in the Compact 5-3-3 particles. These trends for palladium and uranium distribution in the $\mathrm{SiC}$ layer were consistent with those observed in as-irradiated compacts (Hunn et al. 2013-1; Hunn et al. 2014-1). In the particles extracted from the compacts safety tested at $1800^{\circ} \mathrm{C}$, there was a suspicious reduction in the amount of palladium in the $\mathrm{SiC}$. Where fission product clusters located close to the IPyC/SiC interface typically contained palladium and uranium in as-irradiated or $1600^{\circ} \mathrm{C}$ safety-tested compacts, particles from compacts that had been heated to $1800^{\circ} \mathrm{C}$ showed mostly uranium, with palladium concentrations being relatively lower or absent. Where fission product clusters located further from the IPyC/SiC interface typically contained just palladium in as-irradiated or $1600^{\circ} \mathrm{C}$ safety-tested compacts, particles from compacts that had been heated to $1800^{\circ} \mathrm{C}$ showed small clusters of carbon-rich material. These carbon-rich zones are thought to mark the locations where palladium was initially located at the start of the $1800^{\circ} \mathrm{C}$ safety test. Similar results indicating the apparent release of palladium trapped in the $\mathrm{SiC}$ during irradiation have been observed in other compacts tested at 1700-1800 ${ }^{\circ} \mathrm{C}$ [Hunn et al. 2012-2; Hunn et al. 2013-3].

SiC degradation was observed in 5 of the 15 particles from Compacts 5-1-3 and 3-2-3 randomly-selected for IMGA and subjected to additional microstructural analysis (Figure 16-Figure 19). This degradation did not penetrate the $\mathrm{SiC}$ layer or lead to cesium release during the safety test. However, given the number of particles that did have failed $\mathrm{SiC}$ after $300 \mathrm{~h}$ at $1800^{\circ} \mathrm{C}$, it is not surprising that other particles were at various stages of degradation that may have ultimately led to additional cesium release. Clearly, extended exposure of these high-burnup particles to temperatures around $1800^{\circ} \mathrm{C}$ can be expected to significantly reduce their fission product retention performance. 


\section{ACKNOWLEDGMENTS}

This work was supported by the U.S. Department of Energy, Office of Nuclear Energy, under the Very High Temperature Reactor Technology Development Office Advanced Gas Reactor Fuel Development and Qualification Program. Analysis of leach solutions and CCCTF furnace components was provided by the ORNL Nuclear Analytical Chemistry \& Isotopics Laboratory. Hot cell activities were supported by the staff of the ORNL Irradiated Fuels Examination Laboratory (IFEL).

\section{REFERENCES}

Baldwin, C.A., P.A. Demkowicz 2012. "First Elevated Temperature Performance Testing of Coated Particle Fuel Compacts from the AGR-1 Irradiation Experiment." Paper HTR2012-3-027. Proceedings of the HTR 2012. Tokyo, Japan October 28-November 1, 2012.

Collin, B.P. 2012. AGR-1 Irradiation Test Final As-Run Report. INL/EXT-10-18097, Rev. 1. Idaho National Laboratory, Idaho Falls, ID.

Demkowicz, P.A., J.D. Hunn, S.A. Ploger, R.N. Morris, C.A. Baldwin, J.M. Harp, P.L. Winston, T.J. Gerczak, I.J. van Rooyen, F.C. Montgomery, and C.M. Silva 2014. "Irradiation Performance of AGR-1 High Temperature Reactor Fuel." Paper HTR2014-31182. Proceedings of the HTR 2014. Weihai, China, October 27-31, 2014.

Kercher, A.K., and J.D. Hunn 2005. Results from ORNL Characterization of Nominal $350 \mu \mathrm{m}$ LEUCO Kernels from the BWXT G73D-20-69302 Composite. ORNL/TM-2005/517. Oak Ridge National Laboratory, Oak Ridge, TN.

Harp, J.M. 2013. Analysis of Individual Compact Fission Product Inventory and Burnup of the AGR-1 TRISO Experiment Using Gamma Spectrometry. INL/ECAR-1682, Rev. 2. Idaho National Laboratory, Idaho Falls, ID.

Hawkes, G.L. 2012. AGR-1 Daily As-Run Thermal Analyses. INL/ECAR-968, Rev. 3. Idaho National Laboratory, Idaho Falls, ID.

Hunn, J.D., and R.A. Lowden 2006-1. Data Compilation for AGR-1 Baseline Coated Particle Composite LEU01-46T. ORNL/TM-2006/019, Rev. 1. Oak Ridge National Laboratory, Oak Ridge, TN.

Hunn, J.D., and R.A. Lowden 2006-2. Data Compilation for AGR-1 Variant 1 Coated Particle Composite LEU01-47T. ORNL/TM-2006/020, Rev. 1. Oak Ridge National Laboratory, Oak Ridge, TN.

Hunn, J.D., F.C. Montgomery, and P.J. Pappano 2006-1. Data Compilation for AGR-1 Baseline Compact Lot LEU01-46T-Z. ORNL/TM-2006/507, Rev. 0. Oak Ridge National Laboratory, Oak Ridge, TN.

Hunn, J.D., F.C. Montgomery, and P.J. Pappano 2006-2. Data Compilation for AGR-1 Variant 1 Compact Lot LEU01-47T-Z. ORNL/TM-2006/508. Oak Ridge National Laboratory, Oak Ridge, TN.

Hunn, J.D., T.W. Savage, and J.S. Kehn 2012. AGR-1 Irradiated Compact 6-4-2 PIE Report: Preparation and Analysis of Polished Compact Sections. ORNL/TM-2012/285. Oak Ridge National Laboratory, Oak Ridge, TN.

Hunn, J.D., T.W. Savage, and C.M. Silva 2012. AGR-1 Fuel Compact Pre-Irradiation Characterization Summary Report. ORNL/TM-2012/295. Oak Ridge National Laboratory, Oak Ridge, TN.

Hunn, J.D., R.N. Morris, C.A. Baldwin, F.C. Montgomery, C.M. Silva, and T.J. Gerczak 2012-1. AGR-1 Irradiated Compact 6-1-1 PIE Report: Evaluation of As-Irradiated Fuel Performance using Leach Burn Leach, IMGA, Materialography, and X-ray Tomography. ORNL/TM-2012/233. Oak Ridge National Laboratory, Oak Ridge, TN.

Hunn, J.D., R.N. Morris, C.A. Baldwin, F.C. Montgomery, and C.M. Silva 2012-2. PIE on Five Irradiated AGR-1 Compacts. ORNL/LTR-2012/397. Oak Ridge National Laboratory, Oak Ridge, TN. 
Hunn, J.D., R.N. Morris, C.A. Baldwin, F.C. Montgomery, C.M. Silva, and T.J. Gerczak 2013-1. AGR-1 Irradiated Compact 4-4-2 PIE Report: Evaluation of As-Irradiated Fuel Performance with Leach Burn Leach, IMGA, Materialography, and X-ray Tomography. ORNL/TM-2013/236. Oak Ridge National Laboratory, Oak Ridge, TN.

Hunn, J.D., R.N. Morris, C.A. Baldwin, and F.C. Montgomery 2013-2. Safety Tests on Irradiated AGR-1 Compacts 4-1-2, 4-4-3, and 4-4-1. ORNL/LTR-2013/290. Oak Ridge National Laboratory, Oak Ridge, TN.

Hunn, J.D., R.N. Morris, C.A. Baldwin, F.C. Montgomery, C.M. Silva, and T.J. Gerczak 2013-3. PIE on Three Irradiated AGR-1 Compacts in FY2013. ORNL/LTR-2013/291. Oak Ridge National Laboratory, Oak Ridge, TN.

Hunn, J.D., R.N. Morris, C.A. Baldwin, F.C. Montgomery 2013-4. Safety Tests on Irradiated AGR-1 Compacts 5-3-3 and 5-1-3. ORNL/LTR-2013/603. Oak Ridge National Laboratory, Oak Ridge, TN.

Hunn, J.D., C.A. Baldwin, T.J. Gerczak, F.C. Montgomery, R.N. Morris, and C.M. Silva 2014-1. AGR-1 Irradiated Compacts 5-2-3 and 5-2-1 PIE Report: Evaluation of As-Irradiated Fuel Performance with Leach Burn Leach, IMGA, Materialography, and X-ray Tomography. ORNL/TM-2014/171. Oak Ridge National Laboratory, Oak Ridge, TN.

Hunn, J.D., C.A. Baldwin, T.J. Gerczak, F.C. Montgomery, R.N. Morris, C.M. Silva, P.A. Demkowicz, J.M. Harp, S.A. Ploger, I.J. van Rooyen, and K.E. Wright 2014-2. "Detection and Analysis of Particles with Failed SiC in AGR-1 Fuel Compacts." Paper HTR2014-31254. Proceedings of the HTR 2014. Weihai, China, October 27-31, 2014.

Hunn, J.D., R.N. Morris, C.A. Baldwin, F.C. Montgomery, and T.J. Gerczak 2014-3. PIE on SafetyTested AGR-1 Compacts 4-1-2 and 4-4-3. ORNL/LTR-2014/101. Oak Ridge National Laboratory, Oak Ridge, TN.

Ploger, S.A., P.A. Demkowicz, and J.D. Hunn 2012. Ceramographic Examinations of Irradiated AGR-1 Fuel Compacts. INL/EXT-12-25301, Rev. 1. Idaho National Laboratory, Idaho Falls, ID.

Sterbentz, J.W. 2013. JMOCUP As-Run Daily Depletion Calculation for the AGR-1 Experiment in ATR B-10 Position. INL/ECAR-958, Rev. 2. Idaho National Laboratory, Idaho Falls, ID. 